\title{
AVALIAÇÃO CEFALOMÉTRICA DAS ALTERAÇÕES DENTOESQUELÉTICAS DE JOVENS COM MÁ OCLUSÃO DE CLASSE II DENTÁRIA TRATADOS COM DISTALIZADORES JONES JIG
}

\section{Mayara Paim Patel}

\begin{abstract}
Dissertação apresentada à Faculdade de Odontologia de Bauru da Universidade de São Paulo, como parte dos requisitos para obtenção do Título de Mestre em Odontologia, área de Ortodontia.
\end{abstract}





\title{
AVALIAÇÃO CEFALOMÉTRICA DAS ALTERAÇÕES DENTOESQUELÉTICAS DE JOVENS COM MÁ OCLUSÃO DE CLASSE II DENTÁRIA TRATADOS COM DISTALIZADORES JONES JIG
}

\section{Mayara Paim Patel}

\author{
Dissertação apresentada à \\ Faculdade de Odontologia de Bauru \\ da Universidade de São Paulo, como \\ parte dos requisitos para obtenção do \\ Título de Mestre em Odontologia, \\ área de Ortodontia.
}

ORIENTADOR Prof. Dr. José Fernando Castanha Henriques 


\section{Patel, Mayara Paim}

P272a Avaliação cefalométrica das alterações dentoesqueléticas de jovens com má oclusão de Classe II dentária tratados com distalizadores Jones jig./ Mayara Paim Patel - Bauru, 2006.

176p. + apêndices: il.; $30 \mathrm{~cm}$

Dissertação (Mestrado) - Faculdade de Odontologia de Bauru. Universidade de São Paulo

Orientador: Prof. Dr. José Fernando Castanha Henriques

Autorizo, exclusivamente, para fins acadêmicos e científicos, a reprodução total ou parcial desta dissertação/tese, por processos fotocopiadores e outros eletrônicos.

\section{Assinatura:}

\section{Data:}

Comitê de Ética da FOB: Projeto de pesquisa aprovado em 11 de maio de 2004.

$N^{\circ}$ do Protocolo: 06/2004 




\section{Dados Curriculares}

22 de julho de 1980

Filiação

$1998-2003$

$2002-2004$

$2005-2007$

Associações
Nascimento - Palotina - PR

Valério Bruno Patel

Lizete de Fátima Paim Patel

Curso de Graduação em Odontologia Universidade do Sagrado Coração USC-Bauru/SP

Curso de Aperfeiçoamento em Ortodontia na ACOPEN - Bauru

Curso de Pós-Graduação em Ortodontia, em nível de Mestrado, pela Faculdade de Odontologia de Bauru Universidade de São Paulo

Associação Paulista de Especialistas em Ortodontia e Ortopedia Facial APEO 


\section{DEDICATÓRIA}

Dedico essa vitória a $\boldsymbol{D E} \boldsymbol{U S}$.... Soberano em todas as decisões e superior a qualquer conquista. Ser iluminado que me abencoou durante essa longa caminhada, esteve presente em momentos de tristeza, dificuldade, felicidade e realizações. Pai de todas as horas, agradeço cada caminho que me mostraste. Meu obrigada hoje e sempre.

'NÃO TE JULGUES SOZINHO NA LUTA PURIFICADORA, PORQUE O SENHOR SUPRIRA TODAS AS NOSSAS NECESSID ADES.

ERGUE TEUS OLHOS PARA O ALTO E , DE QUANDO EM QUANDO, CONTEMPLA A RETAGUARDA.

SE TE ENCONTRAS EM POSIÇÃO DE SERVIR, AJUDA E SEGUE.” 


\section{DEDICATÓRIA}

A MEUS PAIS, pessoas magnificas, consideradas meu alicerce em todas as horas. Dedico este trabalho a vocês, meus pais, pois compreendo que inúmeras vezes, vocês abriram mão dos seus sonhos para que eu pudesse estar aqui hoje. Digo mais, essa conquista é nossa, pois sei o quanto vocês a desejaram e me apoiaram para que eu fosse capaz de alcançar essa vitória e sei também que sem vocês eu não teria chegado sozinha.

Minha amada mãe Lizete, mãezinha, como de costume. Mulher de garra, batalhadora e "mãezona". Imaginem vocês que essa mulher vive exclusivamente para educar seus filhos, não mede esforços e está sempre à disposição. Você minha mãe é um exemplo de perseverança e de amor. Amo muito você!

Meu paizão Valério, homem de objetivos, sempre esteve a meu lado a fim de ensinar-me e esclarecer-me os tropeços da vida; você foi meu conselheiro durante essa fase, me espelhei em sua luta e em suas conquistas. Passamos alguns meses de sufoco e com a graça de Deus, tenho a oportunidade de mais uma vez, dizer que the amo.

A MEUS IRMÃOS, Karolyne e Bruno, meus eternos amores, companheiros e confidentes; mesmo distante, estiveram a meu lado em todas as horas.

Kazynha a meus olhos você é uma pessoa original, dona de si, sonhadora e confiante. Infelizmente, tivemos poucos anos de convívio, mas o que me consola é saber que esse esforço foi em razão de uma causa nobre, a concretização de nossos sonhos. Querida, te amo de paixão!

Bruninho, meu irmão de sangue e filho de coração. Tenho por você um sentimento de amor inexplicável, como você mesmo diz, me considero sua segunda mãe. Você é um ser iluminado que faz parte desta minha vida, traz alegria e muito amor no coração. Amo muito você. 
A minha avó Maria Patel, que mesmo distante, esteve sempre orando e torcendo pelo meu sucesso, Rezou por cada viagem que realizei para que chegasse sempre salva a meu destino.Meu sincero obrigada!

A men avôs (in memorian) Doilho Patel, Hélio e Virgínia Paim que estiveram a meu lado em todos os momentos de dificuldade e onde quer que estejam, certamente, estão a presenciar esta conquista.

A meu amado Gui, meu cúmplice. Soube me apoiar em todos os momentos, me compreender pelas ausências e principalmente, compartilhar dos meus sonhos. Vocêfoi muito importante para a realização deste trabalho, embora distante, suas palavras me acalmaram em momentos de angústia. Meu eterno obrigada! Te amo!

Ao Sr. Davi e D. Maria Helena, meu muito obrigada! Agradeço por me acolherem em sua família, pelo carinho sincero e preocupação de sempre. Fico felizpor poder compartilhar esta conquista com pessoas de bom coração. 


\section{AGRADECIMENTO ESPECIAL}

Ao men orientador Prof. Dr. José Fernando Castanha

Henriques, uma pessoa admirável, esteve a meu lado em todos os momentos difíceis, de incertezas e de realizações. Um exemplo de mestre, de pai e de pessoa; um exemplo a ser seguido. Pessoa prestativa que me estendeu a mão em todas as horas, não me deixou desamparada e sempre me mostrou o lado simples da vida, quando chegava achando que lhe traria um problema, ele em poucas palavras desembaraçava rapidamente a situação. Esse mesmo incentivo que o Sr. diversas vezes me passou, também foi transmitido alguns anos atrás a meu pai, diante da dificuldade em continuar sua especialização. Portanto, mais um motivo para lhe agradecer, já que o Sr. não o deixou desistir. Muito obrigada! Estendo todo o meu carinho e a minha gratidão a sua esposa, D. Arlete e a sua filha Fernanda, sempre muito prestativas, a seu filho e nora Rafael e Paola, um casal sempre alegre e disposto a ajudar.

Ao coordenador do curso de Mestrado em Ortodontia desta Faculdade, Prof. Dr. Guilherme Janson, um mestre sempre à disposição. Um exemplo de educador. Talvez, como dir a maioria, exigente demais, porém essa é uma característica singular para uma pessoa que assume responsabilidades e que vive constantemente a Ortodontia. Reconbeço que cada pedido de atenção significou um conhecimento a mais em minha bagagem profissional. A partir de suas considerações, passei a observar o meu dia a dia com outros olhos, busco perguntas e respostas claras, vejo resultados de forma mais crítica e certamente, todas essas mudanças fazem parte de uma evolução como pessoa. Obrigada por participar desta minha etapa evolutiva. 
A pessoa que inicialmente me encaminhou a Ortodontia,

Prof. Dr. Arnaldo Pinzan, honrosamente, meu professor desde a graduação; incentivador de meu segundo projeto de pesquisa. Agradeço pela atenção, pelo apoio e pelos ensinamentos. Serei eternamente grata a sua esposa, D. Célia, e estendo meu carinho a seus pais Sr. João e D. Irmãa, ás suas filhas, genros e netos, Célia Regina, Alex, Guilherme e Henrique, Veridiana, Cláudio, Clara e Luciana. O Sr. e sua família me acolheram em um momento em que me vi longe de meus familiares, depositaram confiança em minha pessoa. Agradeço cada momento de dedicação.

A um professor que considero um grande amigo, um exemplo de pai e um ser iluminado; Prof. Dr. Marcos Roberto de Freitas. O Sr. é um mestre brilhante, mostrou-se caminhos e concedeu-me muito conhecimento. Admiro-o por sua capacidade, inteligência e pelo coração generoso. Estendo minhas considerações a sua esposa Lene, sempre carinhosa e atenciosa, a seus filhos Karina e Daniel e a seu neto Thiago.

Aos professores Dr. Décio Rodrigues Martins, Dr. Renato Rodrigues de Almeida, agradeço pela atenção, dedicação e paciência. Cada ensinamento será sempre lembrado, os Srs. foram fundamentais para a conclusão deste curso, realizaram o dever de ensinar de forma brilhante. São pessoas de grande experiência e merecem sempre um reconbecimento especial. Estendo minha gratidão a seus familiares.

Sinto-me na obrigação e não vejo melhor oportunidade para agradecer a duas pessoas que não imaginam a importância que apresentam em minha vida; Prof. Dr. Valdir Janson e Prof. Dr. Interlandi. Dois seres ilustres e incentivadores profissionais. Agradeço pela oportunidade e pela confiança cedidas a meu pai Valério Bruno Patel; os Srs. abriram portas importantes e fundamentais para o seu crescimento; diante disso, me possibilitaram estar aqui no dia de hoje. 


\section{AGRADECIMENTO}

Aos amigos do curso de Mestrado: Caio, Danilo, Douglas, Eduardo, Janine, Leonardo, Luiz Fernando, Luiz Filiphe, Patrícia, Rachelle, Tassiana e Vladimir; pela aprendizagem, amizade e convivência do dia a dia. Durante meses vocês fizeram parte de minha vida e tornaram-se minha família; caracterizada por risos, conselhos, discussões e principalmente compreensão. Agradeço cada palavra e cada sorriso a mim direcionados; sou grata pelo carinho e pelo apoio de sempre; saibam que levarei lembranças agradáveis desse momento impar.

Aos amigos da especialização, Celso, Evandro, Fabiano, Lauana, Márcia e Vitor; obrigada pelo carinho, pela torcida sincera, pelos votos de sucesso e pela confiança.

Aos colegas do curso de Doutorado: Alexandre, Carlos Cabrera, Carlos Henrique, Darwin, Fernando Pedrin, Fernando Torres, Kelly, Lívia, Marcos, Marise, Paula, Rafael, Renata e Sérgio; pelo apoio e carinho; apesar do pouco convívio, vocês foram importantes durante esse período de aprendizagem.

Aos amigos do doutorado antigo: Analu, Célia Regina, Fabrício, Fernanda, José Eduardo, Karina Freitas, Karina Lima, Leniana, Rejane, Ricardo e Rodrigo; pela disposição e pela atenção de sempre. Obrigada pelo carinho!

Em especial, agradeço Analu, Karina Lima, Leniana, Rejane, Renata, Rodrigo e Sérgio pelo convívio e pela disposição de sempre. Vocês demonstraram uma amizade incondicional e estiveram dispostos a ensinar, realizaram um importante papel de educadores. Meu muito obrigada! 
A Kelly, uma pessoa sincera, iluminada e de um coração imenso. Meu agradecimento sincero pela disposição, pela ajuda de sempre e principalmente pela generosidade de todas as horas.

Ao Fabrício Valarelli, que além de amigo, costumo chamá-lo de mestre; pois foi importantíssimo em meu aprimoramento clínico; agradeço cada minuto que disponibilizou para me ajudar no tratamento dos pacientes da amostra. Considere-se fundamental para a realização e sucesso deste trabalho.

Janine, uma amiga de alma, amiga de todas as horas. Compartilhamos tristezas, felicidades e conquistas. Amiga, você é um presente que recebi de Deus, considero-a um ser de luə,, uma pessoa iluminada que esteve ao meu lado constantemente, foi minha confidente e conselheira; poderia dizer que foi uma grande irmã. Aprendi muito com sua maturidade, serenidade e principalmente, com sua persistência e alegria de viver. Querida, agradeço intensamente pela ajuda de sempre.

\section{Angeline, Evellyn, Leonardo, Luiz Filiphe e Vladimit,}

grandes amigos que me acompanham desde o aperfeiçoamento e que se tornaram companheiros fiéis, obrigada pela disposição, pelo apoio e pelo carinho. Guardo de vocês ótimas lembranças.

A Daniel (Bonné), um amigo que conquistei nesses anos todos de FOB, uma pessoa que a cada palavra amiga, me estimulava a continuar de cabeça erguida, sem desanimar. Agradeço em especial à ajuda despendida para formatação deste trabalho.

Ao Celso Tinôco Cavalcanti, uma pessoa que pouco convivi, mas que foi responsável pelo meu ingresso com o Jones jig, cedeu-me todo o material inicialmente obtido, esteve à disposição no processo inicial desta pesquisa e concedeu-me vasto conhecimento sobre o assunto. 
À Maria Fernanda Martins-Ortiz pelo carinho e pela disposição de sempre. Considero-a uma incentivadora e ótima educadora. Você é um exemplo de perseverança.

À minha querida amiga Karina Freitas, esteve a meu lado desde men primeiro pedido de "socorro", sempre me apoiando e me ajudando na elaboração de trabalhos. Ultimamente, a correria do dia a dia nos distanciou, mas nossa amizade se renova a cada reencontro. Você é uma pessoa especial, batalhadora, exemplo de garra. Estendo esse agradecimento a seu filho amado, Thiago, criança serena e de uma inteligência incontestável; começo a pensar que é um "mal de família" (risos).

À querida Lívia Freitas (Baiana), pelo apoio e pelo carinho de sempre. Sou grata pelos conselhos e pela disposição de todas as horas, inclusive as altas madrugadas a frente do computador. Amiga, você é uma pessoa que transmite alegria, que demonstra raça e persistência. Meu sincero agradecimento. Estendo esse sentimento fraterno a sua querida filha Maria Eduarda, menina meiga e carinhosa.

Às minhas amigas Amanda, Déia, Kazuza e Renata pelo incentivo, pela paciência e compreensão diante das ausências constantes. Amigas, vocês moram em meu coração e estarão a meu lado sempre. Um agradecimento especial pelo convívio de anos e pela evolução de cada etapa acompanbada uma a uma. Estendo minha gratidão a todos os seus familiares, por me receberem sempre com muito carinho.

A uma amiga especial, Dani, que faz parte de minha vida bá pouco tempo, mas muito me conhece. Obrigada por me ouvir a cada sessão de fisioterapia, agradeço pelos conselhos, pela paciência e ensinamentos espirituais. 
A Sônia (Soninha), uma amiga especial; sempre à disposição, um ombro amigo de todas as horas. Um exemplo de responsabilidade e de dedicação. Levarei cada sorriso e cada lágrima que derramamos juntas; obrigada por cada palavra de consolo e por cada gesto de carinho.

A Maristela, funcionária da biblioteca desta Faculdade; agradeço pelo olhar sincero, pelas palavras amigas e pelo carinho de sempre.

Aos funcionários da Disciplina de Ortodontia desta Faculdade, Verinha, Sérgio, tia Maria, Cristina, Neide, Luciana e Cláudia, pela disposição de todos os dias. Agradeço pelo sorriso que encontrei em cada rosto. Estendo esse agradecimento ao Danilo, que esteve sempre presente no dia a dia do departamento.

Aos funcionários da Biblioteca e da Pós-Graduação pela atenção e disponibilidade com que sempre me atenderam.

Aos funcionários da Acopen Sônia, Lú, César, Daniel (Bonné), Waltinho e Dona Délia, pelo carinho e pela ajuda de sempre, tornando o dia a dia mais agradável.

Aos professores e funcionários da FOB-USP, pelos conhecimentos transmitidos e pela ajuda.

Ao Prof. Dr. Luiz Fernando Pegoraro, diretor da Faculdade de Odontologia de Bauru, Universidade de São Paulo.

Ao Prof. Dr. José Carlos Pereira, vice-diretor da Faculdade de Odontologia de Bauru, Universidade de São Paulo,. 
A Prof(a). Dr(a). Maria Aparecida de Andrade Moreira Machado, Presidente da Comissão de Pós-Graduação da FOB-USP.

Ao Prof. José Roberto Lauris pela orientação na parte estatística desta pesquisa.

Aos meus pacientes, agradeço pela confiança e por me permitir estar aprimorando meus conhecimentos. Em especial, aos pacientes da amostra, pela paciência e compreensão; sem vocês este trabalho não poderia ser realizado.

A Capes, pela concessão da bolsa de estudos durante toda a realização deste Mestrado.

Enfim, a todos que colaboraram direta ou indiretamente para a realização desta conquista. 



$$
\text { IRESUIIIO }
$$




\section{RESUMO}

Nesta pesquisa foram avaliados 30 pacientes, sendo 15 para cada gênero, idade iniciais entre 10,83 e 16,24 anos, sendo a média de idade inicial 13,32 anos; leucodermas, brasileiros, naturais da cidade de Bauru, caracterizados por má oclusão de Classe II $1^{\mathrm{a}}$ e $2^{\mathrm{a}}$ divisão de Angle, na presença ou não dos segundos molares superiores e sem comprometimento esquelético. Os jovens pertencentes a essa amostra receberam o aparelho Jones jig a fim de distalizar os molares superiores a uma relação molar de "super Classe I"; sendo que em média esse dispositivo permaneceu por 0,86 anos, ou seja, 10 meses e 10 dias. Ao final da sobrecorreção, os molares distalizados receberam um botão de Nance e como ancoragem extrabucal, o AEB com tração média-alta (capacete jeans); com o intuito de verticalizar e corrigir a angulação radicular dos molares distalizados. Foram realizadas tomadas radiográficas em dois diferentes tempos; ou seja, telerradiografias em normal lateral inicial (T1) e pós-distalização (T2) a fim de avaliar as alterações dentárias e esqueléticas decorrentes do aparelho Jones jig. As medidas cefalométricas foram submetidas ao teste $t$ dependente de Student para avaliar as alterações de T1 para T2 e o teste $t$ independente para avaliar o dimorfismo entre os gêneros e os efeitos provocados pela presença dos segundos molares superiores. Com base nos resultados obtidos e a partir da metodologia empregada observou-se alterações dentárias significantes como movimentação distal linear e angular dos segundos e primeiros molares superiores, assim como intrusão no sentido vertical; sendo que a taxa de distalização mensal foi de 0,26mm. Também se confirmou efeitos indesejáveis como a perda de ancoragem refletida em mesialização, extrusão e angulação mesial dos segundos pré-molares, protrusão dos incisivos superiores, aumento do overbite e overjet. Pode-se confirmar que certas movimentações dentárias promovem significantes alterações esqueléticas de estruturas localizadas à distância, ou seja, observou-se extrusão significante dos segundos pré-molares superiores, o que resultou em rotação mandibular, aumento significante da altura facial ântero-inferior e protrusão do lábio inferior. Observou-se que a presença dos segundos molares superiores interfere significantemente apenas no resultado 
final da angulação distal dos primeiros molares superiores e que as maiorias das variáveis se correlacionam significantemente entre si. 



$$
\text { Absteret }
$$





\section{ABSTRACT}

Thirty patients were evaluated in this study, 15 males and 15 females, leukoderm, Brazilian, natural from Bauru city, with initial ages ranging from 10.83 years to 16.24 years, being the average age 13.32 years old. They were characterized by Angle Class II division I and II malocclusion, with or without the second maxillary molars, and, no skeletal compromising. The patients were treated with the appliance Jones jig. The treatment last for 0.86 years. It's purpose was the distalization of the first maxillary molars to normal molar relationship. After this movement, the maxillary molars were anchored with Nance button, and extraoral headgear was used to correct tipping of the distalized molars. Lateral cephalograms were obtained at two observation stages: before treatment, and after distalization to evaluate dental and skeletal changes of appliance Jones jig. Cephalometric values were submitted to: dependent sample Student t test to identify changes between T1 and T2, and, independent sample Student $t$ test to evaluate generic dimorphism and the effects from the presence of the second maxillary molars. On the basis of obtained results and applied methodology, significant dental changes were observed, such as distalization, distal tipping, and, intrusion of first maxillary molars, with the monthly rate of distal movement being $0.26 \mathrm{~mm}$. Anchorage loss was also observed, characterized by significant extrusion; mesial movement and tipping of the maxillary second premolar; protrusion of the maxillary incisors; and, increase of the overbite and overjet. It can be said that some dental movements promote significant skeletal changes, such as, significant extrusion of the second maxillary premolars resulted in clockwise mandibular rotation, increase of the lower anterior face height, and, protrusion of the lower lip. Another fact also observed was that the presence of second maxillary molars interfere significantly on the first maxillary molars's distal tipping results, and, that the variables correlate significantly amongst themselves. 

Stirnépio 



\section{SUMÁRIO}

1- INTRODUÇÃO

2- REVISÃO DE LITERATURA 43

2.1 Considerações da má oclusão de Classe II 45

2.2 Tratamento da má oclusão de Classe II --- 47

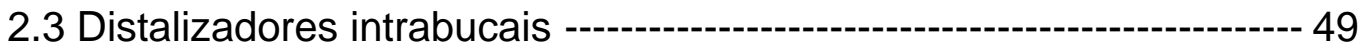

2.3.1.Distalizador Jones jig ------------------------------------------------- 58

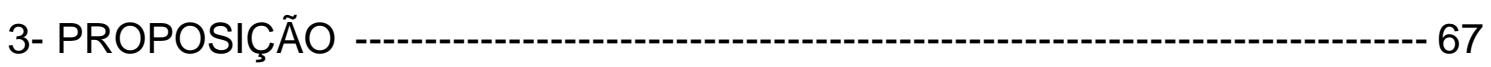

4- MATERIAL E MÉTODOS ------- 71

4.1 Material -------------------------------------------------------------------------- 73

4.1.1 Obtenção da amostra ------------------------------------------- 73

4.1.2 Características da amostra --------- 73

4.2 Métodos -------------------------------------------------------------------- 77

4.2.1 Tratamento ortodôntico com o distalizador Jones jig ---------77

4.2.2 Obtenção das telerradiografias em norma lateral -------------84

4.2.3 Elaboração do cefalograma da telerradiografia em

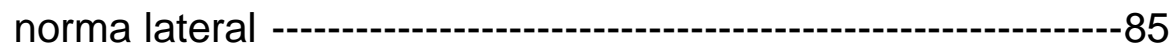

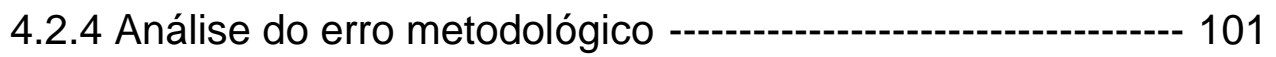

4.2.5 Análise do erro metodológico --------------------------------- 102 
6- DISCUSSÃO -- 119

6.1 Precisão da metodologia --- 121

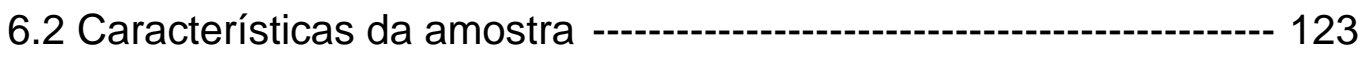

6.3 Considerações da metodologia ------------------------------------- 126

6.4 Resultados ----o 130

6.4.1 Compatibilidade da amostra ---o--- 130

6.4.2 Alterações dentárias e esqueléticas ------------ 131

6.4.2.1 Força de distalização ---------------------------- 131

6.4.2.2 Reforço de ancoragem ---------------------- 135

6.4.2.3 Posicionamento dentário vertical ------------------ 141

6.4.2.4 Severidade da má oclusão de Classe II --------- 145

6.4.2.5 Presença dos segundos molares superiores ---- 146

6.4.2.6 Tempo de tratamento ------------o--o- 148

6.4.3 Alterações do perfil facial ---- 150

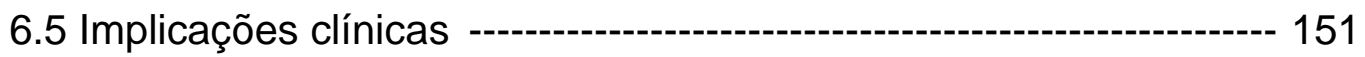

7- CONCLUSÕES ----o- 153

REFERÊNCIAS BIBLIOGRÁFICAS -- 157

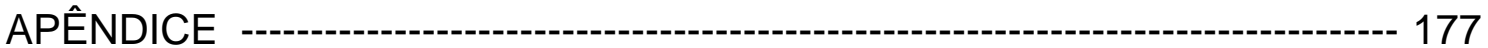




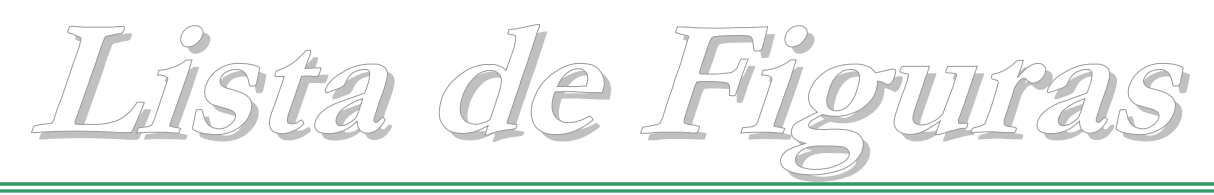





\section{LISTA DE FIGURAS}

FIGURA 4.1 - Fotografias extrabucais iniciais, de um paciente apresentando as características da amostra ---------------------- 75

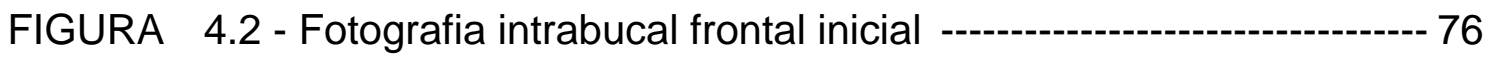

FIGURA 4.3 - Fotografia intrabucal lateral direita inicial --------------------------- 76

FIGURA 4.4 - Fotografia intrabucal lateral esquerda inicial ---------------------- 76

FIGURA 4.5 - Instalação botão de Nance modificado nos segundos

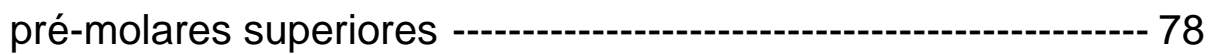

FIGURA 4.6 - Instalação das bandas nos primeiros molares

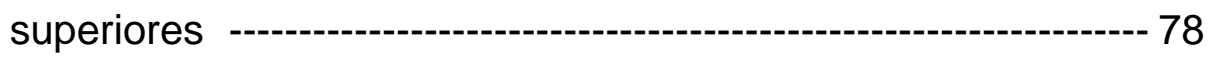

FIGURA 4.7 - Distalizador Jones jig Morelli® - Completo ------------------------- 79

FIGURA 4.8 - Distalizador Jones jig Morelli® - Corpo de aço .036" ------------ 79

FIGURA 4.9 - Distalizador Jones jig Morelli® - Cursor para

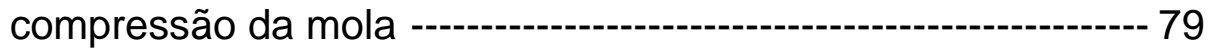

FIGURA 4.10 - Distalizador Jones jig Morelli® - Mola de aço de secção aberta

FIGURA 4.11 - Distalizador Jones jig modificado - corpo de aço e cursor Morelli ${ }^{\circledR}$ e mola secção aberta GH

FIGURA 4.12 - Distalizador Jones jig modificado - pronto para instalação

FIGURA 4.13 - Instalação dos distalizador Jones jig - amarrilho .012" para fixação no acessório da banda do primeiro molar e no botão do segundo pré-molar superior; compressão de $5 \mathrm{~mm}$ da mola de NiTi 80

FIGURA 4.14 - Fotografias intrabucais frontal, lateral direita e lateral esquerda iniciais - Instalação do distalizador Jones jig

FIGURA 4.15 - Fotografias intrabucais iniciais oclusais superior e inferior - Instalação do distalizador Jones jig

FIGURA 4.16 - Fotografias intrabucais frontal, laterais direita e esquerda e oclusal superior sem e com o bloco de acrílico para manutenção do espaço obtido após a distalização - Remoção do distalizador Jones jig 
FIGURA 4.17 - Fotografia intrabucal oclusal superior com botão de Nance nos primeiros molares - ancoragem noturna; fotografias extrabucais frontal e perfil - ancoragem extrabucal tração média-alta (capacete jeans)

FIGURA 4.18 - Telerradiografias em norma lateral inicial e pósdistalização -

FIGURA 4.19 - Desenho anatômico

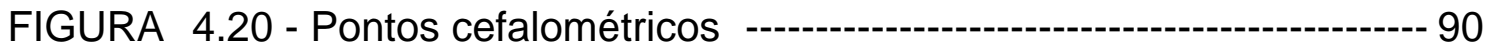

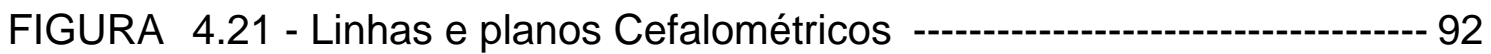

FIGURA 4.22 - Medidas cefalométricas do tecido mole e esquelético --------- 98

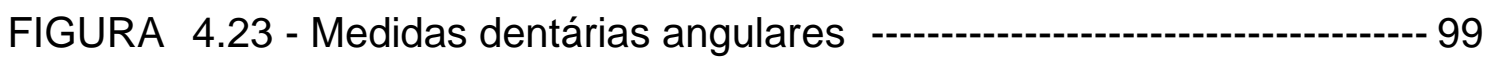

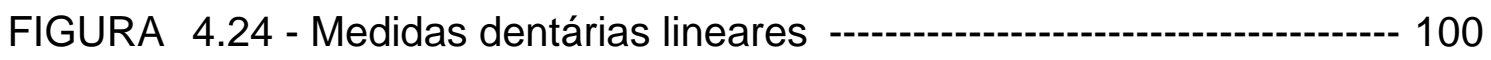

FIGURA 6.1 - Gráfico com valores iniciais e finais das variáveis que representam as alterações dos primeiros e segundos molares superiores

FIGURA 6.2 - Gráfico das variáveis que representam os dentes de ancoragem

FIGURA 6.3 - Gráfico das alterações do trespasse horizontal e vertical

FIGURA 6.4 - Média das alterações dentoalveolares: a) inicial; b) pósdistalização; c) sobreposição inicial x final

FIGURA 6.5 - Gráfico das alterações no sentido vertical dos molares, pré-molares e incisivos superiores

FIGURA 6.6 - Gráfico das variáveis relacionadas ao padrão cefálico, valores inciais e finais.à distalização

FIGURA 6.7 - Gráfico da distribuição dos pacientes quanto à má oclusão de Classe II

FIGURA 6.8 - Gráfico das alterações do perfil mole após a fase de distalização dos molares superiores 


$$
\text { Lista de T'abelas }
$$





\section{LISTA DE TABELAS}

TABELA 1 - Média, desvio-padrão, valores mínimos e máximos para idade inicial, idade final e tempo de tratamento 74

TABELA 2 - Resultado do teste $t$ de Student para dados pareados e Dahlberg para análise do erro metodológico 105

TABELA 3 - Média, desvio-padrão e grau de significância para idade inicial, idade final e tempo de tratamento em relação aos gêneros feminino e masculino (teste $t$ independente

TABELA 4 - Resultado para o teste $t$ independente em relação ao dimorfismo genérico

TABELA 5 - Resultados do teste $t$ dependente para dados pareados

TABELA 6 - Distribuição quanto à má oclusão de Classe II

TABELA 7 - Resultados do teste $t$ dependente para dados pareados em pacientes com no máximo $1 / 2$ Classe II

TABELA 8 - Avaliação quanto à presença dos segundos molares superiores para a distalização linear (teste $t$ independente)

TABELA 9 - Resultado da distalização mensal, valores mínimos e máximos

TABELA 10 - Teste de correlação entre as alterações das medidas dentárias 5-PTV, 6-PTV e 7-PTV e as alterações das variáveis PTV-1, PTV-5, PTV-7 e -6

TABELA 11 - Teste de correlação entre as alterações das medidas dentárias PP-5, PP-6, PP-7, SN.5 e SN.6 e as alterações das variáveis SN.GoGn, NS.Gn, Trespasse Vertical e SN.1 



$$
\text { Inipoducto }
$$





\section{1 - INTRODUÇÃO}

Angle $^{7}$, em 1899, propôs uma das primeiras classificações da má oclusão, que se tornou clássica em Ortodontia. O autor informava que os primeiros molares superiores eram a chave da oclusão e que, portanto sempre estariam em uma posição estável nas bases ósseas, sendo a má oclusão determinada pelo arco inferior, em particular a mandíbula. Com o advento das telerradiografias e com o incremento dos estudos observou-se que na realidade as más oclusões, em especial a Classe II, são de origem multifatorial e que o posicionamento dos primeiros molares superiores nem sempre está correto; ou seja, pode ser provocada por uma discrepância no crescimento maxilomandibular (protrusão maxilar e/ou retrusão mandibular), determinando uma Classe II esquelética ou ainda por fatores dentários, Classe II dentária (rotação dos primeiros molares superiores) $^{157}$

Em uma pesquisa com pacientes Classe II, McNamara ${ }^{119}$, em 1981, concluiu que essa má oclusão geralmente se caracteriza por mínima protrusão maxilar, ocorrendo na maioria dos casos - 60\% - uma retrusão mandibular com correto posicionamento da maxila. Sendo assim, em geral, a má oclusão de Classe II é estabelecida por uma má posição dentária do arco superior, retrusão mandibular ou aumento da altura facial ântero-inferior.

De acordo com uma pesquisa realizada na cidade de Bauru - SP com 2.416 escolares em fase de dentadura mista, entre 7 e 11 anos de idade, observou-se uma prevalência de $11,47 \%$ de oclusão normal e 88,53\% de crianças portadoras de má oclusão, distribuídas em Classe I (48,40\%); Classe II dentária (24,05\%); Classe II divisão 1 esquelética (10,32\%); Classe II divisão 2 esquelética $(3,21 \%)$ e Classe III (2,51\%). Sendo, portanto, 42\% das más oclusões de Classe ${ }{ }^{150}$. De acordo com um estudo realizado por Freitas et $\mathrm{al}^{55}, 50 \%$ dos pacientes que procuram tratamento ortodôntico apresentam má oclusão de Classe II, $1^{\text {a }}$ divisão.

Diversos são os métodos de tratamento para essa discrepância ântero-posterior, sendo, certamente, diversificados a partir do padrão de crescimento e idade do paciente, nível de cooperação e principalmente, queixa principal do paciente; podendo-se optar por um tratamento com extrações dentárias ${ }^{90,91}$ ou sem extrações, por meio da ancoragem extrabucal ${ }^{31}$, elásticos 
intermaxilares, aparelhos removíveis ortopédicos funcionais ou mecânicos ${ }^{92,100}$ e aparelhos intrabucais fixos ${ }^{83,128}$.

O melhor método de tratamento corresponde àquele que promove resultados satisfatórios a partir de uma mecânica simplificada, em um curto período de tempo e se possível, sem depender exclusivamente da participação do paciente, o qual nem sempre, se mostra colaborador. Portanto, diversas alternativas de tratamento vêm sendo desenvolvidas a fim de alcançar tais objetivos $^{21,29,37,53,83,96,128,148}$.

Dentre os métodos para distalização dos molares superiores na correção da má oclusão de Classe II, os dispositivos intrabucais demonstram-se de fácil instalação, rápidos e eficientes para corrigir a relação molar. Contudo, são poucos os estudos de cunho científico, principalmente, a que se refere ao distalizador Jones jig. Desta forma, considerou-se de extrema importância realizar uma pesquisa a fim de avaliar os efeitos dentoalveolares resultantes da distalização com o Jones jig. 


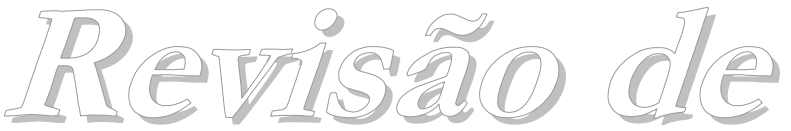 TIIEPEIIIPE!}





\section{2 - REVISÃO DE LITERATURA}

Diante das diversas más oclusões existentes, a má oclusão de Classe I de Angle é considerada a de maior prevalência, sendo $55 \%{ }^{150}$. No entanto, o número de pacientes com Classe II à procura de tratamento ortodôntico é significantemente maior, certamente em decorrência do fator estético ${ }^{3,55,115,149}$.

A má oclusão de Classe II caracteriza-se por fatores esqueléticos e dentários, sendo que as alterações observadas no sentido ântero-posterior se concentram em estruturas basal e/ou dentoalveolar da maxila e mandíbula. Alterações no sentido vertical podem estar associadas a esta má oclusão, agravando ou não o estado oclusal ${ }^{57}$.

A partir de conceitos atuais a respeito da má oclusão de Classe II, o diagnóstico diferencial é de fundamental importância, principalmente em razão do plano de tratamento e da terapia a ser instituída. Portanto, a correção desta má oclusão pode ser alcançada a partir de diversas mecânicas ortodônticas, sendo que cabe ao ortodontista determinar o melhor método para cada paciente.

Para maior entendimento, no decorrer da escrita, esta revisão será dividida em tópicos que facilitam o esclarecimento de um assunto tão vasto como é a má oclusão de Classe II e suas formas de tratamento.

\subsection{Considerações da Má Oclusão de Classe II}

A má oclusão de Classe II vem sendo assunto de estudo por décadas $^{7,8,31,84,102}$ e o principal objetivo é determinar a natureza dessa má oclusão, para que seja realizado um adequado plano de tratamento.

A princípio sabia-se que os molares superiores apresentavam uma posição estática, sendo que o posicionamento dos molares inferiores determinava a má oclusão de cada indivíduo ${ }^{8}$; portanto, na Classe II os molares superiores posicionam-se para mesial em relação aos molares inferiores. Porém, com a evolução de pesquisas observou-se que a alteração determinante da má oclusão poderia ocorrer tanto na maxila como na mandíbula, assim como em ambas as estruturas. 
Essa afirmação vem sendo comprovada por diversos estudos $^{1,13,17,51,74,84,119,122,145,152,162}$, sendo que algumas alterações podem caracterizar a má oclusão de Classe II: dentre elas, 1) o deslocamento mandibular, geralmente provocado por interferências dentárias que forçam a mandíbula para posterior; 2) o arco dentário inferior retruído; 3) a protrusão maxilar com deficiência mandibular; 4) o potencial de protrusão maxilar; 5) a retrusão mandibular; 6) a protrusão bimaxilar; 7) o potencial de protrusão bimaxilar; 8) a diferença relativa no tamanho dos maxilares; 9) a diferença no prognatismo alveolar; 10) a inclinação exagerada dos incisivos e 11) a mobilidade da mandíbula na articulação têmporo-mandibular $9,13,17,39,51,66,81,86$.

Quanto à posição esquelética da maxila em relação à base craniana, os resultados são divergentes. Alguns pesquisadores relatam uma porcentagem de retrusão ${ }^{74,119,135,152}$, outros comprovam a protrusão ${ }^{47,119,152,163}$ e por fim, há os que verificaram a maxila em posição normal ${ }^{47,84,86,119}$.

Com relação à mandíbula, a maioria dos autores relata uma maior freqüência de retrusão em relação à base do crânio ${ }^{47,66,79,84,86,119,135,152}$; alguns observaram um posicionamento normal ${ }^{47,119,152}$ e nenhuma citação de protrusão. Observou-se que o posicionamento espacial da mandíbula não depende apenas do seu crescimento, mas também ocorre de acordo com o deslocamento vertical da maxila, o que altera a morfologia facial ${ }^{146}$. Contudo, o crescimento vertical da maxila por sua vez está diretamente relacionado ao crescimento vertical do plano palatino e principalmente do desenvolvimento vertical dos molares superiores. A extrusão dos molares superiores e a modificação do plano palatino são responsáveis por $70 \%$ do aumento total da altura facial inferior, enquanto que os outros 30\% são atribuídos à extrusão dos molares inferiores ${ }^{41}$.

Dessa forma, na má oclusão de Classe II, de acordo com um estudo de Vigorito $^{164}$ (1973), o plano mandibular na maioria das vezes encontra-se inclinado, caracterizado por uma redução dos tamanhos condilar e do próprio corpo mandibular.

Apesar de a grande maioria dos trabalhos comprovarem que a principal determinante da Classe II é a retrusão mandibular, a protrusão maxilar associada à mandíbula em posição normal também pode caracterizar a má oclusão de Classe $1 I^{142}$. Portanto, diante de inúmeras variáveis da má oclusão 
de Classe II, torna-se evidente a importância do diagnóstico diferencial visando o adequado plano de tratamento $35,81,119,145$.

\subsection{Tratamento da Má Oclusão de Classe II}

O tratamento sem extração, quando bem indicado, proporciona ótimos resultados no que tange a estética, função, estabilidade e saúde bucal ${ }^{31}$. Diversos casos de más oclusões de Classe I e II com apinhamento e protrusão podem ser tratados sem extrações, por meio de placa lábio-ativa, ancoragem extrabucal e barra transpalatina ${ }^{31,78}$. Já nos casos de má oclusão de Classe II em que há comprometimento esquelético devem-se lançar mão de uma terapia ortopédica, principalmente para pacientes em idade precoce e preferencialmente com padrão de crescimento equilibrado ou horizontal.

Se o comprometimento corresponde à protrusão maxilar, diversos tipos de aparelho extrabucal podem ser empregados, sendo necessária uma avaliação cefalométrica quanto ao padrão de crescimento; ou ainda, se o paciente encontra-se na fase de dentadura mista, pode-se utilizar o "splint" maxilar ou o AEB conjugado com o intuito de restringir o crescimento maxilar ${ }^{94}$. Contudo, se a Classe II se estender para a mandíbula, caracterizando uma retrusão mandibular, indica-se o tratamento ortopédico a fim de estimular o crescimento mandibular por meio de aparelho ortopédicos funcionais, dentre eles: ativador, bionator, Herbst, Bimler, APM, Jasper jump, dentre outros $^{36,38,42,94,119}$

Já em casos em que não se pode contar com o crescimento e desenvolvimento do paciente, e diante de uma Classe II severa torna-se necessária uma intervenção cirúrgica associada ao tratamento ortodôntico. Porém, em casos de má oclusão suave ou moderada, é possível optar pela extração dentária caracterizando uma "camuflagem ortodôntica", que para a Classe II corresponde à extração de pré-molares superiores, ou ainda, em casos de severo apinhamento inferior, a extração dentária também no arco inferior $^{131}$.

A ancoragem extrabucal, proposta por Kingsley ${ }^{102}$ (1875), tem sido um dos aparelhos mais utilizados no tratamento da má oclusão de Classe II de Angle. No entanto, apesar deste recurso ter se mostrado efetivo para distalizar 
molares superiores, redirecionar o crescimento e atuar como meio de ancoragem, para alcançar resultados satisfatórios, é necessário que o paciente compreenda e coopere na realização do tratamento, o que nem sempre é conseguido com facilidade. Sendo assim, os ortodontistas passaram a procurar métodos alternativos para a distalização dos molares superiores, que independam da colaboração do paciente e que sejam intrabucais, o que proporciona maior satisfação estética $22,23,30,54,60,65,83,96,99,118,143,147-149,153,158$.

O uso da ancoragem extrabucal foi popularizado por Kloehn ${ }^{108}$, em 1947, como um excelente recurso terapêutico para o tratamento da má oclusão de Classe II. Este método corresponde a um aparelho extrabucal de ancoragem cervical, que possibilita alterações ortopédicas e ortodônticas, porém, apresenta como desvantagem a necessidade de cooperação do paciente para sucesso ao final do tratamento. Kloehn ${ }^{108}$ defendia seu uso precoce, isto é, logo após a irrupção dos primeiros molares permanentes, para que houvesse controle do crescimento maxilar e livre desenvolvimento mandibular, no entanto, acreditava que as maiores correções relacionavam-se a alterações dentoalveolares.

O movimento distal por meio desse dispositivo gerou questionamentos quanto aos efeitos provocados nas estruturas esqueléticas e dentoalveolares. Graber $^{68}$, em 1995, ao estudar o comportamento do aparelho extrabucal, observou que o crescimento alveolar era influenciado por alterações ânteroposteriores das bases apicais. Avaliou 100 pacientes tratados com o aparelho extrabucal e observou que a excessiva angulação distal dos primeiros molares poderia levar à impacção temporária dos segundos molares superiores, sendo que ao cessar as forças extrabucais e ao verticalizar esses dentes, os segundos molares irromperiam facilmente.

Diversas pesquisas foram realizadas com o intuito de avaliar os efeitos resultantes do uso do aparelho extrabucal ${ }^{10,11,68,107,108,121,166}$ e confirmaram que os resultados dependem da direção e intensidade da força aplicada, da tração utilizada e da época de intervenção. Esse aparelho mostrou-se efetivo na distalização dos molares superiores, no entanto, ao final da movimentação distal, alguns casos sofreram angulação dentária ${ }^{68,107,120,121}$. Portanto, para sucesso do tratamento com os aparelhos extrabucais, é imprescindível que se tenha controle da magnitude, direção e duração da força e compreensão da 
mecânica empregada. Dessa forma, resultados mais satisfatórios poderiam ser obtidos se a força aplicada estivesse direcionada o mais próximo possível do centro de resistência dos incisivos e molares superiores, para que os movimentos dentários fossem melhores controlados ${ }^{10}$. O controle da força aplicada no tratamento ortodôntico promove maior efetividade na correção das más oclusões; portanto, a aplicação de forças paralelas ao plano oclusal permite a obtenção de resultados satisfatórios, sendo que o tempo de utilização dos aparelhos está diretamente relacionado à duração do tratamento, assim como os resultados finais.

Outra ressalva importante a se fazer é quanto a maior distalização dos primeiros molares superiores na ausência dos segundos molares. A presença desses dentes durante o movimento distal, certamente influencia na quantidade de distalização, na intensidade da angulação dos primeiros molares e, principalmente, no tempo de tratamento ${ }^{11,108}$. Da mesma forma que os efeitos ortopédicos na maxila dependem de uma intervenção na fase ativa do crescimento $^{166}$, o movimento distal dos primeiros molares superiores é facilmente alcançado se realizado antes da irrupção dos segundos molares e a partir de um sistema de forças contínuas ${ }^{10}$.

Embora o aparelho extrabucal tenha se mostrado efetivo no tratamento da má oclusão de Classe II, para se obter resultados satisfatórios, é fundamental a cooperação do paciente. Portanto, métodos alternativos que não dependam de colaboração dos pacientes têm apresentado maior evidência desde o final da década de 70. Dentre estes dispositivos pode-se destacar o sistema $3 D^{169}$ e 0 BDA ${ }^{168}$, os magnetos ${ }^{65}$, as molas ${ }^{123}$ e os arcos superelásticos $^{113}$, o Jones jig ${ }^{96}$, o pendulum ${ }^{83}$, o distal jet ${ }^{30}$ e o IBMD ${ }^{101}$, entre outros.

\subsection{Distalizadores Intrabucais}

Os distalizadores intrabucais surgiram no intuito de simplificar o movimento de distalização dos molares superiores e principalmente, como uma alternativa para pacientes não colaboradores ${ }^{29,65,83,96,98,101,113,167}$.

A cooperação do paciente é um fator de extrema importância para se alcançar resultados satisfatórios ao final do tratamento ${ }^{2,10,34,40,166}$, e caracteriza- 
se pelo grau em que o paciente altera seu comportamento diante de recomendações clínicas realizadas por profissionais da saúde ${ }^{161}$. A colaboração está diretamente relacionada à idade do paciente, características de personalidade, ao gênero, ao nível sócio-econômico, ao comportamento e à motivação. Sendo que, em Ortodontia, cooperar com o tratamento resume-se à manutenção da higiene bucal adequada, uso de aparelhos extrabucais (AEB), aparelhos removíveis e elásticos intermaxilares. A não cooperação acomete pelo menos 1/3 dos pacientes; geralmente, pais e/ou pacientes superestimam o uso de aparelhos, o que resulta, na maioria dos casos, em insucesso ou tempo prolongado do tratamento ${ }^{161}$. Pacientes acima de 14 anos de idade, geralmente, são pouco cooperadores, pois se sentem independentes, são temperamentais, impacientes, individualistas, nervosos e intolerantes para atividades que envolvam esforço pessoal ou atenção prolongada ${ }^{2}$. Portanto, esse perfil de paciente dificulta o sucesso do tratamento. Nanda; Kierl ${ }^{125}$ observaram que um elogio verbal feito aos pais e aos pacientes resulta positivamente sobre o nível de dedicação ao uso destes aparelhos.

$\mathrm{Na}$ grande maioria dos casos, os pais ou responsáveis mostram maior preocupação quanto à melhoria das características faciais do que com 0 posicionamento dentário ${ }^{40}$; desta forma, a preocupação quanto ao tratamento torna-se mais importante aos pais do que aos próprios filhos ${ }^{44}$.

Outro aspecto que interfere na colaboração refere-se ao gênero; pacientes do gênero feminino, geralmente, se mostram mais colaboradores, pois são motivados pela estética dentofacial ${ }^{34}$. Por essa mesma motivação, pacientes de classe média-baixa são mais cooperadores, pois almejam a aceitação social ${ }^{44}$.

Em suma, para que haja cooperação, é importante que o paciente tenha uma motivação que o faça acreditar no sucesso do tratamento. Para isso, a melhoria na aparência ao longo do tratamento é de extrema importância e reflete credibilidade ao paciente e aos pais ou responsáveis ${ }^{44}$.

Sendo assim, a partir da dificuldade em conscientizar parte dos pacientes e diante da necessidade de se corrigir a má oclusão de Classe II, diversos pesquisadores partiram em busca de recursos que não dependessem da colaboração do paciente. 
A partir da década de 70, dispositivos intrabucais capazes de movimentar os molares superiores para relação molar normal começaram a ser empregados com o intuito de corrigir a má oclusão de Classe II $^{30,65,82,96,101,113,123,134,148,168,169}$.

Wilson $^{167-169}$ desenvolveu dois diferentes dispositivos denominados sistema tri-dimensional $(3 D)^{169}$, instalado internamente (face lingual), que possibilita o controle do nivelamento, distorções do arco, dobras de terceira ordem, distalização rápida dos molares sem o uso do aparelho extrabucal e expansão e fechamento de espaços; já o modelo bimétrico, (BDA) ${ }^{168}$ instalado externamente (vestibular) consiste de extremidades de diâmetro .040", empregados tanto no arco superior como no inferior, uni ou bilaterais, contínuos ou seccionados, capazes de produzir mais de vinte diferentes movimentos funcionais, além de proporcionar a rigidez necessária e o suporte para os aparelhos extrabucais. Esse sistema pode ou não ser associado a outros aparelhos e caracterizam-se por apresentar baixa fricção e intensa força de dissipação. Os componentes de ação responsáveis pela distalização dos molares superiores para o sistema BDA correspondem a uma mola espiral associada a elásticos de Classe II e ao aparelho extrabucal. Torna-se importante ressaltar que a efetividade desse sistema está diretamente relacionada à idade do paciente, à severidade da relação molar, à posição dos incisivos superiores, ao padrão de crescimento e ao posicionamento dos dentes superiores e inferiores. Esse dispositivo destaca-se principalmente por ser intrabucal e não pela mínima cooperação do paciente, já que depende da utilização de elásticos de Classe $\|^{148}$.

Wilson $^{167}$ (1981) recomendou o uso de 12 horas por dia de elásticos de Classe II, por aproximadamente seis semanas para alcançar a relação molar normal. Alguns estudos que avaliaram este sistema relataram a distalização do primeiro molar ${ }^{124,133,160}$ com significante angulação distal; contudo, observaram movimento mesial do molar inferior, protrusão e extrusão dos incisivos superiores $^{124,133,160}$. Porém, como o mecanismo de ação não seguiu exatamente o protocolo do sistema de Wilson ${ }^{168,169}$, os resultados podem não corresponder ao aparelho original. Acredita-se que a angulação dos molares e a protrusão dos incisivos seriam menores diante da utilização do aparelho extrabucal $^{148}$. 
No entanto, poder-se-ia melhorar a efetividade desse sistema diante da extração dos segundos molares superiores, pois facilitaria a distalização dos primeiros molares, permitiria a irrupção normal dos terceiros molares e corrigiria a má oclusão de Classe II em tempo reduzido (4,5 meses) ${ }^{72}$. Em suma, o arco distalizador bimétrico de Wilson ${ }^{167}$ (1981), cujo sistema está associado a elásticos de Classe II, é capaz de corrigir essa má oclusão em curto espaço de tempo.

A partir dos estudos de Miura et al. ${ }^{123}$ (1988), evidenciaram-se importantes propriedades das molas de níquel-titânio (NiTi), ou seja, foi comprovada a capacidade dessas molas em exercer forças leves e contínuas por um longo período de tempo, o que promove um movimento dentário satisfatório. Verificaram que a superelasticidade era evidente, quando as molas abertas eram comprimidas de 15 a 75\%. A partir de uma ativação de 8 $10 \mathrm{~mm}$, as molas superelásticas podem distalizar em média de 1 a 1,5mm por mês ${ }^{63}$. Ao contrário das molas fechadas, as molas abertas apresentavam valores de cargas de superelasticidade mais constantes, o que permitiria alcançar mais facilmente as forças contínuas. Também comprovaram que as molas de NiTi apresentaram estabilidade superior às molas de aço e as propriedades superelásticas se assemelhavam às dos arcos de NiTi de procedência japonesa ${ }^{123}$.

Após comprovar a eficiência das molas de NiTi, o primeiro dispositivo capaz de distalizar os molares superiores a partir de um método diferenciado foi o sistema de magnetos de repulsão preconizado por Gianelly et $\mathrm{al}^{65}$ (1988). Ao final da distalização, comprovaram a eficiência deste distalizador, principalmente, pela rápida movimentação distal dos molares superiores e devido à perda mínima de ancoragem. No entanto, os autores afirmaram que a fase de atuação do distalizador em relação ao desenvolvimento dentário influenciou diretamente na quantidade de distalização dos primeiros molares superiores, já que na presença dos segundos molares era maior o tempo de tratamento e o resultado era menos previsível. Confirmaram que a perda de ancoragem, correspondeu a $20 \%$ do espaço obtido e, provavelmente, seria reduzida por meio de um reforço no botão de Nance modificado. Contudo, freqüentemente, esse método de distalização é acompanhado por rotação distopalatina, angulação distal e extrusão dos molares ${ }^{87}$. 
Em um estudo comparativo entre magnetos e molas superelásticas de $\mathrm{NiTi}$, comprovou-se que as molas de NiTi foram mais efetivas para a distalização dos molares, apesar de ambos terem promovido efeitos clinicamente aceitáveis ${ }^{20,49}$. As molas foram mais constantes e mais confortáveis do que os magnetos; além de que os magnetos são pouco estéticos, de custo elevado e requerem ativação semanal, pois a força magnética chega a diminuir de 50 - 70\% a partir de 0,5 a $1 \mathrm{~mm}$ de movimentação dos molares ${ }^{87}$. Ambas as técnicas promoveram angulação distal e rotação distopalatina dos primeiros molares superiores ${ }^{20,49}$.

Os segundos molares quando presentes também sofrem angulação distal e rotação distopalatina, sendo que esses efeitos, considerados indesejáveis, devem ser corrigidos na fase pós-distalização ${ }^{19}$.

O sistema de magnetos destaca-se por uma característica ainda não explicada cientificamente, os efeitos biológicos dentários são desconhecidos. No entanto, acredita-se na hipótese de que a redução rápida da mobilidade e desconforto durante a distalização é atribuída à propriedade sinergística dos campos magnéticos que rompem o equilíbrio local ${ }^{154}$.

Outro método para distalizar molares superiores e que pode ser comparado às molas superelásticas e aos magnetos é o arco retangular de níquel-titânio "Neosentalloy" que dissipa uma força de 100 gramas e movimenta de 1 a $2 \mathrm{~mm}$ por mês com perda mínima de ancoragem. Os autores $^{113}$ sugerem, para reforço de ancoragem, elásticos de Classe II com 100 a 150 gramas de força ou, para pacientes não colaboradores, a cimentação de um botão de Nance nos primeiros pré-molares.

Diversos são os trabalhos que relatam os resultados da distalização de molares superiores por meio de fios superelásticos de NiTi "Neosentalloy"61,62,113. Esse método de distalização mostra-se efetivo e diante de uma força de distalização de 80 gramas não exige a utilização de uma barra transpalatina ou de um botão de Nance palatino, como reforço de ancoragem; pois as forças são direcionadas aos primeiros e segundos molares distintamente ${ }^{61}$.

A efetividade dos distalizadores, assim como o sucesso do tratamento, é alcançada de acordo com os diferentes estágios de desenvolvimento dentário. Em um estudo comparativo entre molas superelásticas de NiTi e o arco 
retangular de NiTi "Neosentalloy", comprovou-se que para ambos os dispositivos, a quantidade de sucesso varia de acordo com três diferentes estágios de desenvolvimento dentário, na fase de dentadura mista, 90\% dos resultados apresentam sucesso; já na adolescência, a partir da completa irrupção dos segundos molares superiores, a distalização torna-se mais lenta e a perda de ancoragem se intensifica; da mesma forma ocorre na idade adulta, em que o sucesso não é constante, sendo maior o número de falhas ${ }^{62}$.

Durante alguns anos, a distalização dos molares superiores por meio de aparelhos intrabucais esteve em desuso. Contudo, o tratamento da Classe II com distalizadores intrabucais passou a ser novamente evidenciado na década de 90, em decorrência da mínima necessidade de cooperação do paciente. Em 1992, Hilgers ${ }^{83}$ desenvolveu o pendulum, um dispositivo capaz de distalizar molares superiores, cujo mecanismo de ação refere-se a um botão de Nance modificado apoiado ao palato e aos primeiros pré-molares e molas de TMA de .032" que liberam força leve e contínua. Esse dispositivo recebeu inúmeras modificações com o intuito de aumentar o conforto do paciente, facilitar a colocação e ativação do aparelho, simplificar o desenho e melhorar a aceitabilidade $^{82}$. Sendo assim, dentre elas, pode-se citar: inserção do parafuso expansor $^{83}$, o que reduz o tempo de tratamento ${ }^{153}$; a inversão do "loop"147, que permite um movimento de corpo, tanto da coroa como da raiz; a colocação de quatro braços removíveis incluindo os primeiros e segundos pré-molares superiores $^{46}$, com o intuito de diminuir a perda de ancoragem anterior; a fixação de tubos linguais horizontais na banda dos primeiros pré-molares, o que possibilitaria a remoção do botão de $\operatorname{Nance}^{140}$ e a inserção de tubos telescópicos, o que permitiria a remoção e reativações externas das molas de $\mathrm{TMA}^{4}$. A perda de ancoragem pode ser diminuída a partir da cimentação do botão de Nance nos primeiros e segundos pré-molares ${ }^{83}$, e pode ser prevenida se os molares superiores forem estabilizados por pelo menos três meses após a distalização ${ }^{158}$.

De acordo com o preconizador do aparelho pendulum, as reativações deveriam ser executadas a cada 3 semanas, verificando-se a magnitude da força residual. As ativações poderiam ser realizadas interna ${ }^{83}$ ou externamente $^{4}$, de acordo com a modificação desse dispositivo. Com a inserção do parafuso expansor, o aparelho pendulum passou a ser 
denominado pend-x, que ao contrário do distalizador original, deve ser ativado a cada 3 dias, possibilitando uma expansão lenta e favorecendo a distalização dos molares ${ }^{83}$. Outra denominação que se refere às modificações do pendulum é o T-rex que corresponde ao aparelho pendulum com parafuso expansor e uma extensão do apoio oclusal dos primeiros pré-molares para os caninos, o que permite a movimentação dos pré-molares sem necessidade de remover o aparelho $^{117}$.

Dentre os diversos distalizadores, o aparelho pendulum se destaca pela facilidade de confecção, ativação única, a possibilidade de ajuste das molas, se necessário, para corrigir problemas transversais e verticais, nas posições dos molares superiores. Essas foram as conclusões de um trabalho desenvolvido por Gosh; Nanda ${ }^{60}$, em 1996, cujo propósito foi avaliar os efeitos do pendulum na distalização dos molares superiores e os efeitos adversos sobre a unidade de ancoragem, incisivos e pré-molares superiores. Os molares superiores além do movimento distal linear, também apresentaram certa angulação distal e a alteração no sentido vertical não foi estatisticamente significante. Os segundos molares distalizaram menos que os primeiros molares, no entanto, a angulação distal foi maior. Neste estudo, até os terceiros molares foram avaliados, contudo, nenhum paciente apresentava mais do que a metade da raiz em formação e somente as coroas foram radiografadas. Esses dentes angularam para distal, porém, as alterações verticais e horizontais de posição foram insignificantes. Os autores sugerem um estudo longitudinal para avaliar os efeitos da distalização dos primeiros molares superiores considerando angulação, impacção e alteração do padrão irruptivo dos terceiros molares.

Quanto à eficiência dos distalizadores na movimentação distal dos molares, o aparelho pendulum tem mostrado resultados satisfatórios. Apesar da evidente perda de ancoragem, representada pelo aumento da sobressaliência e pela angulação dos molares ${ }^{20,24-26,60,97,98,140,158}$, a quantidade de distalização varia entre $64 \%{ }^{26}$ e $71 \%{ }^{25}$ do espaço obtido entre primeiros molares e segundos pré-molares superiores.

Corrigir a má oclusão de Classe II sem depender da cooperação do paciente esteve em voga principalmente na década de 90. Os dispositivos estavam sendo desenvolvidos com o intuito de sanar as necessidades aparentes nas técnicas de distalização. Em 1992, Jones; White ${ }^{96}$ 
desenvolveram o distalizador Jones jig, caracterizado pela eficiência e rapidez na distalização, assim como, pela facilidade para instalação $3,23,54,96,115,127,149$. Contudo, a partir de inúmeras pesquisas ${ }^{23,76,115}$, esse aparelho apresentou efeitos indesejáveis de maior magnitude em relação aos demais distalizadores. As considerações do distalizador Jones jig serão realizadas adiante, em um tópico específico.

$\mathrm{Na}$ maioria dos sistemas, as forças ortodônticas são aplicadas nas coroas e o movimento distal dos primeiros molares superiores ocorre associado às angulações e rotações das coroas. O distalizador preconizado por Carano; Testa $^{30}$, em 1996, denominado distal jet apresenta uma característica própria; a força de distalização é despendida na face palatina o mais próximo do centro de resistência dos molares, o que diminui a angulação no decorrer do movimento distal. Alguns autores afirmam que esse sistema é capaz de promover um movimento de translação dos molares superiores ${ }^{28,29,132}$. Esse dispositivo é composto de tubos de $0,9 \mathrm{~mm}$, bilaterais, conectados ao aparelho de Nance. Um fio dobrado em forma de uma baioneta é inserido nos tubos linguais dos primeiros molares. Em cada tubo são ajustadas molas de aço e anéis metálicos. A força distalizadora corresponde à aproximadamente 150 gramas e diminui conforme os espaços vão sendo abertos. Para distalização apenas dos primeiros molares, libera-se uma força de até 180 gramas, já para distalizar os primeiros e segundos molares, corresponde a 240 gramas $^{28}$.

Assim como os demais distalizadores, o distal jet também recebeu modificações com o intuito de aprimorar o sistema e eliminar os possíveis efeitos indesejáveis ${ }^{21,28,132}$, sendo assim, quando comparado ao Jones jig e magnetos, ao contrário da maioria dos distalizadores, não provocou angulação ou rotação ao final da distalização dos molares superiores. Os autores ${ }^{29}$ afirmaram que o movimento distal ocorreu por meio de um movimento de corpo e a unidade de ancoragem ântero-superior permaneceu estável. Outra alternativa para distalizar os molares superiores com a mínima cooperação do paciente é por meio do distal jet ancorado a um implante localizado na região anterior do palato, com o intuito de eliminar a perda de ancoragem. Além das considerações já citadas, os autores acrescentaram a possibilidade de carga imediata sobre o implante de ancoragem ${ }^{99}$. Contudo, essa técnica é pouco aceita em decorrência da cirurgia e do elevado custo financeiro ${ }^{148}$. 
No estudo realizado por Keles; Sayinsu ${ }^{101}$, desenvolvido em 2000, foi utilizado um dispositivo composto por um botão de Nance cimentado nos primeiros pré-molares e molas de TMA para o movimento de distalização, capaz de distalizar os primeiros molares superiores de corpo sem promover rotação em seu longo eixo. Essa característica foi comprovada ao final da distalização, com a análise de modelo que não demonstrou alterações na distância intermolar. Porém, os distalizadores intrabucais, geralmente, não promovem esses efeitos. Dessa forma, segundo os autores, diante de um movimento de corpo dos molares superiores, não é necessário utilizar o aparelho extrabucal para verticalizar a raiz desses dentes. Outra variação do estudo de Keles; Sayinsu ${ }^{101}$ (2000) foi em relação ao reforço de ancoragem, que de acordo com as considerações de Gosh; Nanda ${ }^{60}$, o aumento da extensão acrílica do botão de Nance reforçaria o sistema de ancoragem e garantiria menor mesialização do segmento anterior. Essa manobra deve ser considerada, principalmente, porque a tendência do movimento de corpo resulta em maior perda de ancoragem.

Recentemente, Silva; Gasque; Vieira ${ }^{148}$ (2003), desenvolveram um sistema intra-oral de forças biomecânicas, denominado Ertty System, cujo objetivo é distalizar o molar superior em movimento de corpo, assim como, todo o segmento dentário desse mesmo lado, sem provocar efeitos colaterais. 0 aparelho recebe uma única ativação e segundo seus preconizadores elimina a utilização do aparelho extrabucal, no entanto, deve ser associado a elásticos de Classe II, portanto, de qualquer forma, exige cooperação do paciente.

Além dos inúmeros distalizadores descritos nessa revisão $0^{30,65,83,96,101,113,167}$, alguns outros sistemas foram desenvolvidos afim de movimentar os molares superiores em Classe II para uma relação molar norma $\left.\right|^{69,83,98,111,134,141,153}$. No entanto, todos esses dispositivos tem como princípio a dissipação de uma força em direção distal, sendo que como efeito indesejável, ocorre a angulação dos molares movimentados e a perda de ancoragem, isto é, a mesialização dos pré-molares e dentes anteriores, o que resulta, geralmente, em aumento da sobressaliência e do apinhamento ânterosuperior. Esses efeitos podem ser diversificados de acordo com a região da força dissipada e ao reforço de ancoragem empregado. 
Os distalizadores intrabucais, de uma forma geral, são considerados como um recurso prático para correções dentárias ântero-posteriores, visto que esses dispositivos promovem ganho de espaço no arco superior e corrigem a relação molar de Classe II em um curto período de tempo. Também são corretamente indicados para tratamentos assimétricos caracterizados por um desvio da linha média superior, pois permitem ativações unilaterais ${ }^{114}$.

Em suma, dentre as diversas vantagens, os distalizadores intrabucais destacam-se principalmente por não dependerem da cooperação do paciente e, além disso, permitem que o ortodontista tenha maior controle sobre 0 tratamento.

\subsubsection{Distalizador Jones jig}

De acordo com Jones; White ${ }^{96}$ (1992) existem dois tipos de má oclusão de Classe II: a primeira corresponde a uma relação molar de Classe I rotacionada, isto é, os molares superiores encontram-se rotacionados dentro do arco, o que resulta em maior distância mesiodistal ocupada, levando a um posicionamento de pré-molares e caninos em relação de Classe II; o segundo tipo consiste de um posicionamento da cúspide mesiovestibular do primeiro molar superior à frente da crista marginal do primeiro molar inferior. Para corrigir a primeira forma de Classe II, o distalizador Jones jig requer de 90 a 120 dias, já para corrigir uma relação verdadeira de Classe II é necessário de 120 a 180 dias. Como os demais distalizadores, o aparelho Jones jig requer um reforço de ancoragem, que corresponde a um botão de Nance modificado, isto é, fixo nos primeiros ou segundos pré-molares ou ainda, nos segundos molares decíduos. Ao contrário dos demais preconizadores, Jones; White ${ }^{96}$ (1992) contra-indicam seu distalizador para pacientes cujo padrão de crescimento seja vertical, pois, embora a força do distalizador seja aplicada em direção ânteroposterior, a extrusão dos molares não pode ser controlada. No artigo desenvolvido por Jones; White ${ }^{96}$ (1992), em que são apresentados sete casos clínicos, os autores ${ }^{96}$ evidenciam clinicamente a angulação distal dos molares superiores; porém, não confirmam, mas é evidente que ao término da distalização, na maioria dos casos, os molares distalizados apresentam rotação 
dentária em direção disto-palatina ${ }^{127,143,149}$ da mesma forma, os pré-molares, que servem de ancoragem, apresentam rotação mésio-palatina ${ }^{143}$. Os autores consideraram que quando o botão de Nance estiver apoiado nos primeiros prémolares, os segundos pré-molares se movimentam espontaneamente para a distal. Diante de um número reduzido de casos clínicos tratados, se faz necessário um estudo, cuja amostra tenha maior número de pacientes para que os resultados sejam transmitidos de forma fiel à rotina clínica ${ }^{23}$. Dessa forma, diante dessa consideração, recomenda-se ${ }^{143}$ que os resultados de estudos com número reduzido de pacientes sejam aplicados clinicamente no planejamento de casos individuais.

Para confiabilidade dos resultados torna-se necessário realizar estudos criteriosos e esclarecedores, embasados principalmente, no considerável número de pacientes avaliados ${ }^{23}$. Brickman; Sinha, Nanda ${ }^{23}$ a partir de uma extensa revisão literária afirmaram: "Nos artigos revisados para a preparação desse artigo, nós encontramos estudos de movimentação distal de molar que consistem de casos clínicos ou que incluem pequenas amostras constituídas de 8 a 19 pacientes. Conclusões baseadas em amostras com número limitado de pacientes, não são precisas devido à variabilidade individual que pode distorcer os resultados". Portanto, o número de pacientes avaliados influencia consideravelmente os resultados obtidos, porém, essa questão não é considerada pela maioria dos autores, já que, grande parte dos trabalhos baseia-se em média em 15 pacientes, como mostra os estudos de Haydar; Uner $^{76}$ (2000), Jones; White ${ }^{96}$ (1992), Bolla et al. ${ }^{18}$ (2002), Runge; Martin; Bukai $^{143}$ (1999), Oliveira; Eto ${ }^{127}$ (2004), Maia et al. ${ }^{115}$ (2004) e Keles; Sayinsu ${ }^{101}$ (2000).

Outra consideração importante refere-se à metodologia empregada. A maioria dos trabalhos que avaliam os efeitos dos distalizadores intrabucais ou até mesmo os aparelhos extrabucais utiliza como referência linhas e planos comuns à maioria dos estudos e, geralmente referenciam essas medidas no decorrer do $\operatorname{artigo~}^{143}$. Contudo, outros ${ }^{76}$ baseiam-se em medidas que não são convencionais aos demais estudos similares. Desta forma, para os leitores que não se atentam à metodologia, ao realizarem uma análise comparativa com os demais trabalhos, possivelmente, interpretariam os resultados de maneira errônea. Portanto, se a metodologia empregada não estiver de acordo com a 
convencional, é necessário referenciar a metodologia utilizada, ou até mesmo, justificar as medidas empregadas.

Oliveira; Eto ${ }^{127}$, em 2004, desenvolveram um estudo para avaliar os efeitos do distalizador Jones jig e basearam-se na metodologia de trabalhos anteriores $^{23,126,143}$, no entanto, apesar de possibilitarem a comparação dos resultados com os demais trabalhos, a amostra consistiu de seis pacientes, o que comprometeu a aplicabilidade dos resultados. Contudo, os autores justificaram o pequeno número de pacientes por ser um estudo piloto e reconheceram que uma amostra maior deve ser realizada para que seja possível confirmar os resultados encontrados.

Maia et al. ${ }^{115}$, no mesmo ano, desenvolveram um estudo com o intuito de comparar os efeitos de dois diferentes distalizadores intrabucais: o Jones jig e o distal jet. Os autores indicaram a remoção dos dispositivos intrabucais a partir da relação molar de Classe I ou "super Classe I", no entanto, além de não afirmarem de forma convicta a importância de se realizar esse procedimento, também não quantificam a sobrecorreção, o que dificulta a aplicabilidade clínica das considerações provenientes dos autores. A partir dos resultados, foi possível afirmar que o distal jet, apesar de estatisticamente não significante, resulta em menor movimento pendular quando comparado ao Jones jig; porém, ambos promoveram uma angulação dos molares distalizados; da mesma forma, observaram angulação dos incisivos superiores, sendo mais pronunciada nos pacientes tratados com o Jones jig. Também se comprovou que esses distalizadores corrigem más oclusões apenas de ordem dentária; as alterações esqueléticas promovidas por esses dispositivos foram estatisticamente insignificantes.

O distalizador Jones jig ${ }^{96}$, é constituído por um fio .036" inserido no tubo redondo do acessório soldado à banda do molar a ser distalizado. Nesse corpo é inserida uma mola de secção aberta de níquel-titânio, que em ativação libera uma força de 70 a 75 gramas sobre os primeiros molares. Acima deste fio está soldado um fio de .016" que é encaixado no "slot" retangular do tubo do molar e orienta o movimento distal.

Durante a instalação o ortodontista não deve provocar dobras compensatórias ao longo do corpo do distalizador para que não altere o seu mecanismo de ação. A ativação do aparelho é realizada por meio de um fio de 
ligadura .010" que comprime o cursor em direção ao braquete do segundo prémolar. A mola deve ser ativada em $5 \mathrm{~mm}$ e não deve ser excessivamente comprimida, com o intuito de evitar forças intensas, e conseqüentemente, perda de ancoragem. A reativação da mola pode ser realizada no período de 5 a 8 semanas após a instalação do distalizador ${ }^{54,96,127,129}$.

Como ancoragem, é utilizado um botão de Nance cimentado, geralmente, nos segundos pré-molares, quando estes estiverem totalmente irrompidos, caso contrário, o dispositivo de ancoragem pode ser cimentado nos primeiros pré-molares ou segundos molares decíduos ${ }^{104}$. O botão de Nance é confeccionado com um fio de 0,9mm e resina acrílica que se estende desde a porção central do palato até a mesial dos caninos sem tocar a papila incisiva ${ }^{23,54,60,96,101}$. Com o intuito de eliminar possíveis interferências oclusais, sugere-se adicionar ao botão de Nance, uma maior extensão de acrílico no sentido vertical a fim de evitar o contato oclusal ${ }^{63}$. No entanto, esse levantamento de mordida não é considerado ideal, pois causaria provável extrusão dos molares, resultado esse nem sempre desejável; mas já esperado na distalização com dispositivos intrabucais ${ }^{96}$.

Diante da rapidez do tratamento, da eficiência dos resultados e da praticidade de instalação o distalizador Jones jig apresenta certos efeitos indesejáveis, tais como: 1) perda de ancoragem $23,76,96,127,143$, 2) aumento significante do overjet e da altura facial ântero-inferior $\left.(A F A I)^{23,143}, 3\right)$ rotação distal dos molares superiores ${ }^{127}$.

Tanto a eficiência da distalização quanto a perda de ancoragem podem ou não ser alteradas na presença dos segundos molares superiores. A utilização de dispositivos intrabucais na distalização dos primeiros e segundos molares simultaneamente é uma efetiva opção de tratamento para a má oclusão de Classe II, no entanto, a perda de ancoragem e a variação individual para cada paciente têm sido seriamente consideradas $^{118}$. Ao contrário de alguns trabalhos ${ }^{24,25,60,124}$, cujos resultados não se alteram diante da presença ou não dos segundos molares, alguns outros autores ${ }^{11,23,65}$ relatam que a distalização dos primeiros molares superiores depende do estágio de irrupção dos segundos molares. Isto é, o movimento distal de primeiros e segundos molares simultaneamente pode resultar em maior tempo de tratamento ${ }^{63,64}$, maior angulação ${ }^{20}$, menor quantidade de distalização e maior perda de 
ancoragem $3,64,65,105,113,140$. Portanto, uma alternativa para minimizar esses efeitos indesejáveis seria realizar a distalização do segundo molar previamente ao primeiro molar superior ${ }^{62}$. Contudo, relata-se que também ocorra uma maior angulação dos segundos molares diante do germe dos terceiros molares superiores, sendo assim, a extração do terceiro molar é recomendada ${ }^{103}$.

Certamente, a distalização dos primeiros molares superiores apresentará resultados diferenciados se os segundos molares não estiverem completamente irrompidos. Na literatura que abrange o comportamento dos distalizadores intrabucais, alguns trabalhos relatam os diferentes efeitos da distalização dos molares superiores na presença ou não dos segundos molares $3,11,23,62,64$. Sendo que a distalização dos primeiros molares superiores em pacientes jovens apresenta melhores resultados se realizada previamente ao irrompimento do segundo molar superior ${ }^{104}$.

Afirma-se que na presença dos segundos molares, os primeiros molares superiores tendem a retornar para mesial ${ }^{62}$. Esse relato foi comprovado por Andreasen; Naesig ${ }^{5}$ (1968) que notaram que 90\% do movimento distal produzido pelo extrabucal apresentam recidiva em uma semana após a remoção do aparelho sem qualquer tipo de contenção.

Diante de uma severa Classe II e na presença de segundos e terceiros molares, alguns autores sugerem a extração dos segundos molares para facilitar as grandes distalizações ${ }^{83,170}$. No entanto, é imprescindível que se tenha conhecimento da posição e do tamanho dos terceiros molares, para que posteriormente esses dentes possam irromper naturalmente ocupando parte do espaço do segundo molar extraído.

O aparelho Jones jig ${ }^{96}$ foi desenvolvido com o intuito de distalizar os molares superiores e ser assim, mais um coadjuvante no tratamento da má oclusão de Classe II. Diante de inúmeras vantagens como, baixo custo, facilidade de ativação, comprovada eficiência em distalizar os molares superiores e mínima dependência do paciente, este aparelho vem se tornando muito utilizado no tratamento da má oclusão de Classe II. Porém, os distalizadores intrabucais, como quaisquer outros aparelhos ortodônticos, também apresentam contra-indicações como a perda de ancoragem anterior que se reflete clinicamente pelo aumento do trespasse horizontal ${ }^{23,53}$ e maior apinhamento dentário do segmento anterior ${ }^{50}$. Outros efeitos indesejáveis 
correspondem à angulação distal, rotação e extrusão dos molares superiores, que resulta no aumento da AFAl, assim como a dificuldade em higienizar 0 botão de Nance, considerado em muitos sistemas intrabucais, como a unidade de ancoragem ${ }^{76}$.

Dentre os efeitos indesejáveis, a perda de ancoragem do segmento anterior é geralmente relatada pela maioria dos autores 3 3,23,60,76,96,113,118,127,143,149 e corresponde à mesialização dos pré-molares e vestibularização dos incisivos ou aumento da severidade do apinhamento ântero-superior. De acordo com Jones; White ${ }^{96}$ (1992) a perda de ancoragem fora evidenciada principalmente em casos em que o Jones jig e o botão de Nance estiveram associados ao aparelho fixo, pois correspondera ao alinhamento e nivelamento do arco superior. Para minimizar, ou até mesmo, evitar o movimento mesial do segmento ântero-superior, alguns autores sugerem a utilização de elásticos de Classe II para uso noturno ${ }^{23,29,62,65,96,113}$ ou o extrabucal com arco em $\mathrm{J}^{23}$. Outro método também indicado para reforço de ancoragem seria aumentar a extensão de acrílico do botão de Nance que está apoiado sobre o palato $^{23,30,59,60,101,153}$.

A partir dessa manobra poder-se-ia questionar quanto à injúria provocada pelo botão de Nance. Ao contrário do que se imagina, esse dispositivo de ancoragem, na maioria dos casos, não provoca injúrias ao palato $^{29,54}$. No entanto, na rotina clínica, a queixa principal do paciente, referese à dificuldade em higienizar esse dispositivo, porém, esse procedimento deveria ser obrigatoriamente realizado pelo próprio ortodontista.

Outro efeito indesejável, característico não só ao Jones jig, mas também aos demais distalizadores intrabucais, refere-se à angulação da coroa dos molares distalizados 3,54,60,118,149,151. Esse movimento pendular está diretamente relacionado ao vetor de força e ao centro de resistência, isto é, se o vetor de força passar acima do centro de resistência, resulta-se em uma angulação radicular distal e movimento mesial da coroa. No entanto, se o vetor de força passar abaixo do centro de resistência, ocorre angulação mesial de raiz e distal de coroa. Portanto, o ideal é que a força de distalização encontre-se o mais próximo possível do centro de resistência radicular (trifurcação das raízes dos primeiros molares superiores); sendo assim, sugere-se que o tubo vestibular da 
banda dos molares a serem distalizados seja soldado mais cervicalmente do que o normal, o que resultaria em menor angulação distal da coroa ${ }^{70}$.

Diante desse movimento pendular, torna-se necessária a distalização radicular e conseqüente verticalização dos molares distalizados, portanto, indica-se a utilização do aparelho extrabucal como contenção noturna ${ }^{60,62,76}$. Sendo assim, nessa fase, a manutenção dos resultados obtidos durante a distalização pode estar comprometida, já que, o uso do extrabucal depende inteiramente da cooperação do paciente ${ }^{60}$.

Outro efeito negativo provocado pela maioria dos distalizadores corresponde à rotação dos primeiros molares superiores, sendo que, se considerada significante, poderia certamente resultar em uma mordida cruzada posterior $^{143}$. Portanto, os distalizadores, principalmente o Jones jig, não são capazes de controlar o centro de rotação dos molares durante o movimento de distalização ${ }^{76,118,127,143,149}$. Esse efeito não é observado com a mesma intensidade em casos tratados com o distalizador distal jet ${ }^{29,30,115}$, ou mesmo com o pendulum que apresenta alças de ajuste horizontal capazes de corrigir alterações rotacionais ${ }^{83}$.

Outro ponto de discussão de alguns autores ${ }^{23,70,76,96,143}$ é quanto ao comportamento dos molares e pré-molares superiores, que pode

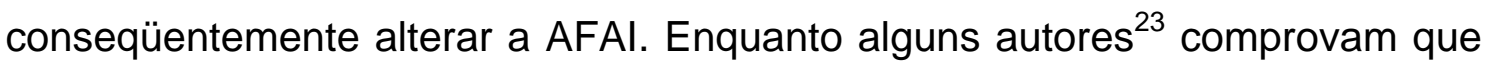
não há extrusão significante desses elementos dentários quando comparados aos pacientes do grupo controle com relação molar de Classe I, outros relatam resultados contrários ${ }^{70,76,96,143}$

A extrusão dos molares distalizados fora relatada no estudo pioneiro de Jones; White ${ }^{96}$ (1992), sendo novamente observada em um estudo comparativo realizado por Haydar; Uner $^{76}$ (2000), cujo resultado mostrou-se estatisticamente significante, principalmente no grupo com distalizador Jones jig. O tempo médio de tratamento para corrigir a relação molar foi significantemente menor (2,5 meses) com o distalizador intrabucal quando comparado ao aparelho extrabucal (10,7 meses).

No estudo de Brickman, Sinha, $\mathrm{Nanda}^{23}$, realizado no ano de 2000, comprovou-se que, ao contrário dos primeiros molares superiores, os segundos molares extruíram significantemente, no entanto, os autores não confirmaram a verdadeira razão deste movimento, eles apenas sugeriram que "pode 
provavelmente" ser atribuído aos diferentes estágios de irrupção entre os primeiros e segundos molares.

Os molares distalizados geralmente tendem a mesializar após a remoção do aparelho distalizador, principalmente diante da presença dos segundos molares superiores. Portanto, a distalização realizada por aparelhos intrabucais requer uma contenção com o intuito de se evitar a perda de ancoragem dos molares distalizados. Diversos dispositivos podem ser empregados a fim de conter o espaço obtido, dentre eles: barra palatina ou botão de Nance cimentado aos primeiros molares superiores associados ou não a uma ancoragem extrabucal, aparelhos fixos associados ao arco utilidade ou arco contínuo, e placa de Hawley modificada ${ }^{157}$. A ancoragem extrabucal é um método vantajoso em relação às demais contenções, pois além de manter o molar na posição distalizada também realiza a distalização radicular ${ }^{62}$, sendo recomendada preferencialmente uma tração alta ${ }^{23}$.

Todo movimento dentário pode estar associado a uma recidiva, isto é, o dente movimentado retorna à posição inicial. Quando se pensa em distalização de molares superiores por meio de dispositivos intrabucais, um dos pontos mais preocupantes, na maioria dos casos, refere-se à mesialização dos molares movimentados, ou seja, à recidiva. Isso porque, a maioria dos distalizadores movimenta os molares por angulação, sendo que a subseqüente verticalização da raiz, promove uma ligeira movimentação mesial da coroa desses dentes. O mesmo não seria necessário se a distalização ocorresse por translação ${ }^{31}$; portanto, a má oclusão de Classe II deve ser sobrecorrigida ${ }^{25,32}$.

A maioria dos trabalhos ${ }^{23,26,32,127}$ relata o movimento mesial dos primeiros molares superiores ao final da distalização e principalmente, durante a retração do segmento ântero-superior, contudo, são raros os autores que recomendam sobrecorrigir a relação molar, visando a possível mesialização dos molares e conseqüentemente, recidiva da Classe ${ }^{70,127}$.

A sobrecorreção é considerada essencial para o sucesso do tratamento com distalizadores intrabucais ${ }^{19,20,62,70,98}$. Considera-se necessário distalizar a cúspide mesial dos molares superiores $1 \mathrm{~mm}$ além do sulco vestibular dos primeiros molares inferiores, manobra essa denominada "super Classe I" de molar $^{127}$. 
No entanto, baseados em trabalhos anteriores ${ }^{23}$, a recidiva da distalização dos molares superiores, geralmente, corresponde de $2 \mathrm{~mm}$ a 2,50mm de deslocamento mesial. Portanto, a sobrecorreção de $1 \mathrm{~mm}$, sugerida por Oliveira; Eto ${ }^{127}$ (2004), não é suficiente para evitar a recidiva da Classe II na fase de verticalização dos molares; o ideal seria sobrecorrigir essa má oclusão em $2 \mathrm{~mm}^{32}$.

Diversos trabalhos ${ }^{19,20,22-}$ $26,29,30,33,46,49,50,53,57,61,65,76,83,87,96,101,111,114,117,118,123,124,126,132,143,149,151,158,160,168,169$

se propuseram a avaliar as alterações promovidas por distalizadores intrabucais, no entanto, a maioria são artigos clínicos sendo que apenas alguns são de cunho científico; portanto, em virtude dessa limitação, é evidente a necessidade de se realizar pesquisas detalhadas que evidenciam o real mecanismo de ação, efeitos pós-distalização e estabilidade dos resultados. 
PPOPOSITETO 



\section{3 - PROPOSIÇÃO}

A proposta desta pesquisa é avaliar cefalometricamente as possíveis alterações decorrentes da distalização dos primeiros molares superiores com o distalizador Jones jig em jovens brasileiros, leucodermas, com má oclusão de Classe II de Angle, visto que, os diversos trabalhos que se propuseram a avaliar as alterações promovidas por distalizadores intrabucais, são, na maioria, artigos clínicos sendo que apenas alguns apresentam aspecto científico; portanto, em virtude dessa limitação, os objetivos dessa pesquisa são:

3.1 - Verificar os efeitos esqueléticos após a distalização;

3.2 - Avaliar a distalização dos molares superiores;

3.3 - Observar o comportamento dos dentes de ancoragem;

3.4 - Analisar a correlação entre as variáveis dentárias e esqueléticas 



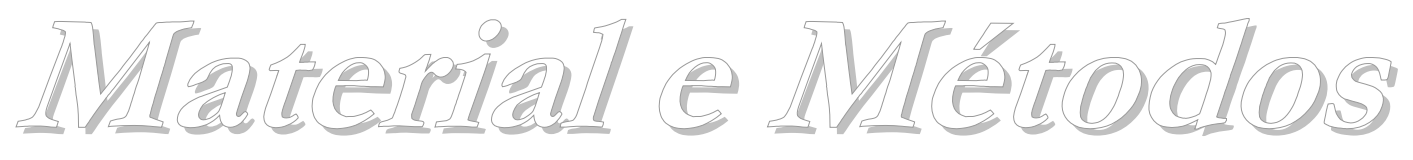

= 



\section{4 - MATERIAL E MÉTODOS}

\subsection{MATERIAL}

\subsubsection{Obtenção da Amostra}

Os pacientes foram selecionados na Clínica de Pós-Graduação da Faculdade de Odontologia de Bauru - Universidade de São Paulo e nas Escolas Estaduais da cidade de Bauru. Os critérios para seleção da amostra basearam-se nas seguintes características:

1. Presença da má oclusão de Classe II, $1^{\mathrm{a}}$ ou $2^{\mathrm{a}}$ divisão de Angle;

2. Má oclusão de origem dentária, sem comprometimento das bases apicais;

3. Presença de todos os dentes permanentes, pelo menos, até o primeiro molar superior;

4. Moderado apinhamento superior e inferior;

5. Forma do arco superior aceitável, isto é, sem comprometimento transversal;

6. Ausência de tratamento ortodôntico prévio;

7. Não houve distinção de gênero entre os jovens selecionados;

8. Pacientes na faixa etária dos 10 aos 16 anos.

\subsubsection{Características da Amostra}

A amostra constou de 60 telerradiografias em norma lateral, de 30 pacientes, leucodermas, brasileiros de ambos os gêneros (15 do gênero feminino e 15 do masculino), com idade inicial entre 10,91 anos (10 anos e 11 meses) e 16,24 anos (16 anos e 3 meses).

Os pacientes selecionados apresentaram idade inicial média de 13,32 anos (13 anos e 4 meses), sendo que ao final do tratamento apresentaram idade média de 14,18 anos (14 anos e 2 meses) (Tabela 1) (Figuras 1 a 4). Esses pacientes receberam o aparelho Jones jig, que foi empregado por um período médio de 0,55 anos (6,88 meses), para a distalização dos molares 
superiores e foram tratados até obter a sobrecorreção média de $2 \mathrm{~mm}$ a partir da relação molar normal, o que evitou a possibilidade de recidiva ao final da distalização e durante o período de contenção.

TABELA 1- Média, desvio-padrão, valores mínimos e máximos para idade inicial, idade final e tempo de tratamento.

\begin{tabular}{l|c|c|c|c}
\hline \hline \multicolumn{1}{c|}{ VARIÁVEIS (ANOS) } & MÉDIA & DP & MÍNIMA & MÁXIMA \\
\hline IDADE INICIAL & 13,629 & 1,357 & 10,914 & 16,761 \\
\hline IDADE FINAL & 14,176 & 1,414 & 11,328 & 17,228 \\
\hline TEMPO TRATAMENTO & 0,547 & 0,292 & 0,219 & 1,781 \\
\hline \hline
\end{tabular}



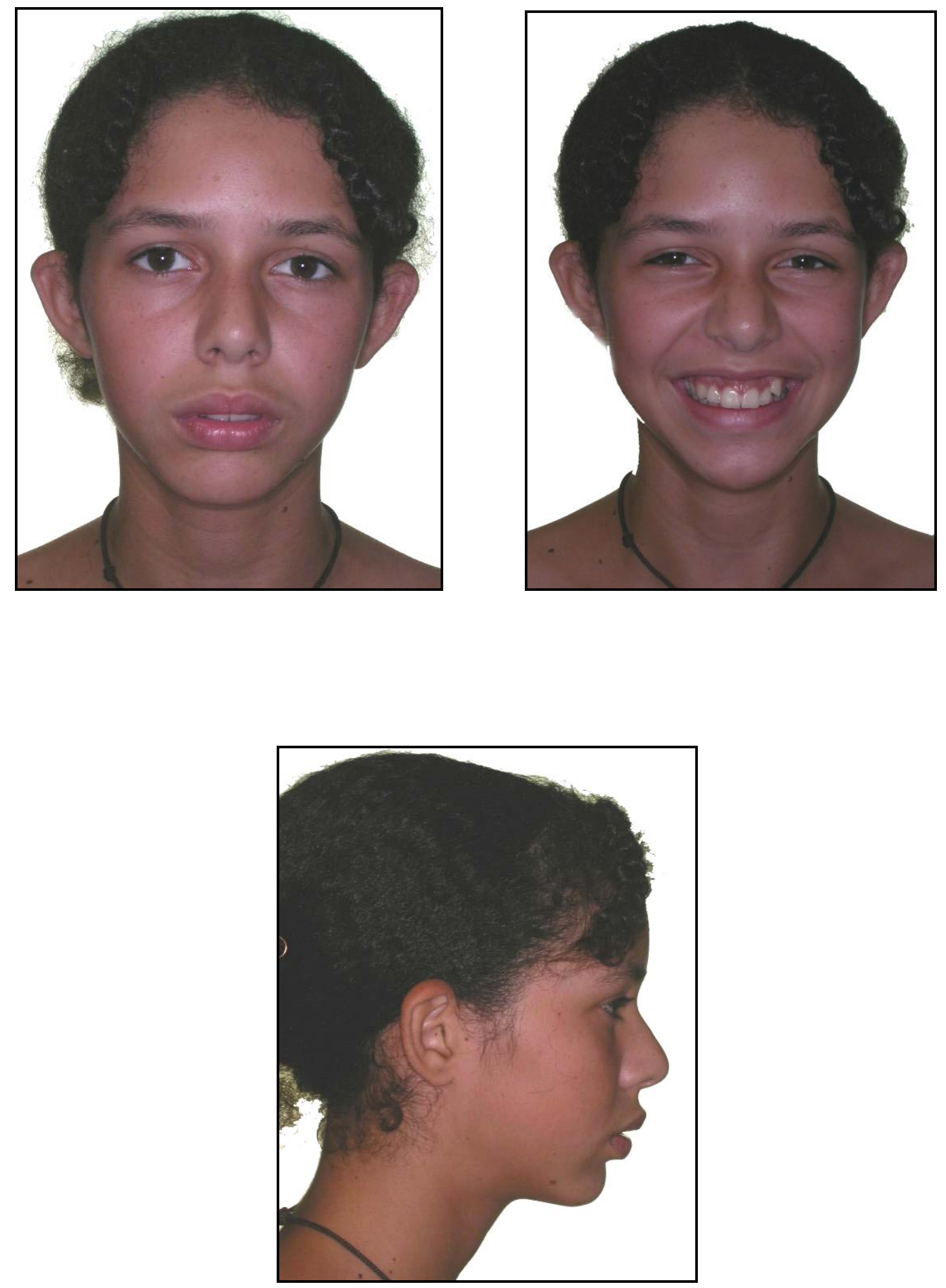

FIGURA 4.1 - Fotografias extrabucais iniciais, de um paciente apresentando as características da amostra 


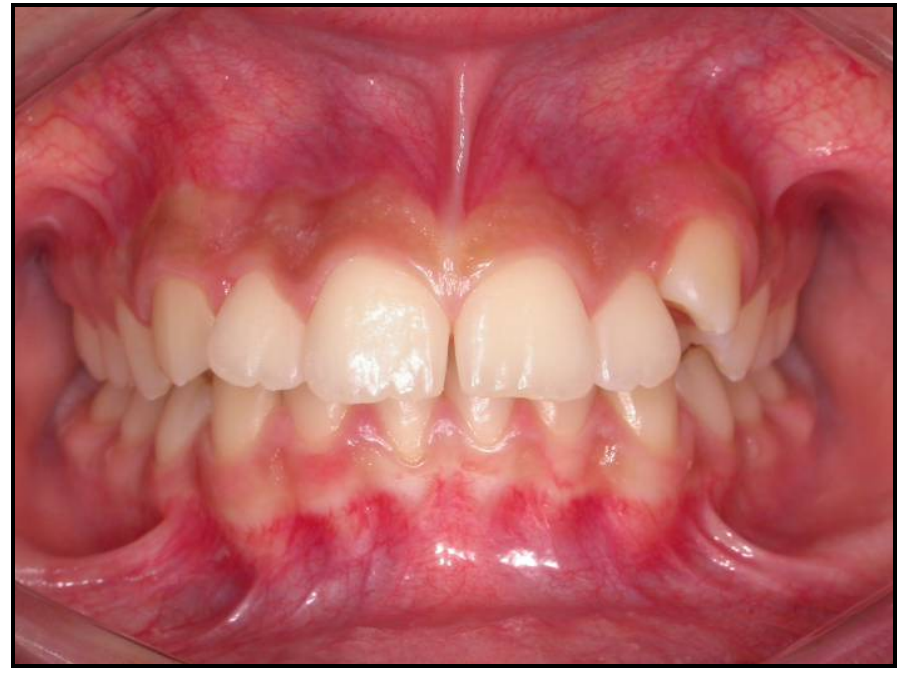

FIGURA 4.2 - Fotografia intrabucal frontal inicial

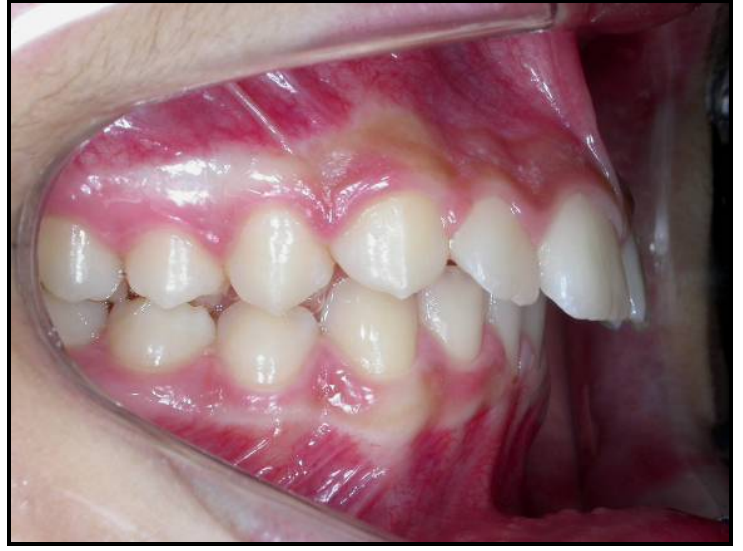

FIGURA 4.3 - Fotografia intrabucal lateral direita inicial

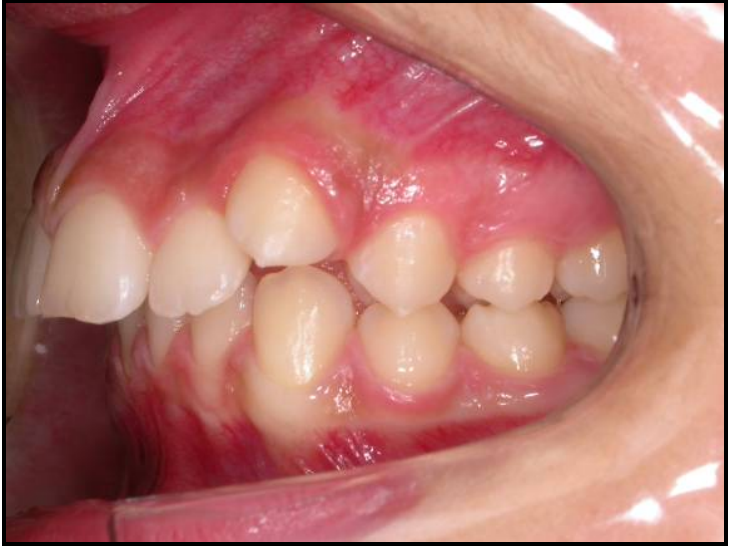

FIGURA 4.4 - Fotografia intrabucal lateral esquerda inicial 


\subsection{MÉTODOS}

O método constituirá de:

4.2.1 Tratamento ortodôntico com o distalizador Jones jig;

4.2.2 Obtenção das telerradiografias em norma lateral na fase inicial e após a distalização;

4.2.3 Elaboração do cefalograma e mensuração das radiografias;

4.2.4 Controle do erro;

4.2.5 Análise estatística dos resultados

\subsubsection{Tratamento Ortodôntico com o Distalizador Jones jig}

Após selecionar os pacientes e realizar a documentação ortodôntica inicial, a partir dos segundos pré-molares superiores foram confeccionadas as bandas com botões soldados na face vestibular para posterior moldagem e obtenção do modelo de gesso com a finalidade de construir o botão de Nance modificado (Figura 4.5). Após confecção desse dispositivo, foi realizada a instalação das bandas com tubos triplos da marca nacional Morelli ${ }^{\circledR}(30.45 .001)$ nos primeiros molares superiores assim como a cimentação do botão de Nance nos segundos pré-molares superiores (Figura 4.6). Realizou-se a modificação do distalizador Jones jig, cujo dispositivo original corresponde a um corpo de aço .036", uma extremidade distal de aço .016", um cursor de aço na extremidade mesial e uma mola aberta de aço inox que exige ativações seqüenciais (Figuras 4.7 a 4.10); portanto, com o intuito de dissipar uma força suave e contínua, substituiu-se a mola aberta de aço por uma mola de secção aberta de níquel-titânio em média 10mm, da marca GH (Greenwood, USA \& Canadá) (Figura 4.11). Em seguida, recortou-se e dobrou-se a extremidade mesial do corpo de aço a fim de diminuir a extensão vestibular do distalizador (Figura 4.12).

Finalizadas as modificações, inseriu-se a extremidade distal de .036" do distalizador Jones jig no tubo redondo do acessório soldado à banda do primeiro molar superior, sendo a extremidade distal de .016" inserida no "slot" retangular desse mesmo acessório. A fim de fixar esse dispositivo ao tubo do molar, utilizou-se um fio de ligadura metálica de .012". Seqüencialmente, o cursor inserido ao corpo do distalizador fora movimentado em direção a mola 
aberta de níquel-titânio e fixado ao botão soldado na vestibular da banda do segundo pré-molar superior também com um fio de ligadura metálica de .012". A compressão da mola correspondeu a uma distância de $5 \mathrm{~mm}$, o que promoveu uma dissipação em média de 120 gramas de força (Figuras 4.13 a 4.15).

Ao final da distalização e correção da relação molar, procurou-se chegar a uma sobrecorreção média de $2 \mathrm{~mm}$ além da relação molar normal, como margem de segurança para uma possível recidiva. Em uma mesma sessão, o distalizador de Jones jig foi removido e com o intuito de manter o espaço obtido e evitar qualquer tipo de movimentação dentária confeccionou-se imediatamente, um bloco de resina acrílica e posicionou-o entre os primeiros molares e segundos pré-molares superiores ${ }^{157}$ (Figura 4.16). Em seguida, encaminhou-se o paciente ao centro de radiologia a fim de realizar uma nova telerradiografia em norma lateral, assim como radiografia panorâmica e modelos de estudo para avaliar as alterações ocorridas. Em seguida, instalouse uma contenção constituída de um botão de Nance modificado nos molares distalizados associado a uma ancoragem noturna, o aparelho extrabucal de tração média alta (capacete jeans - $O A S P^{\circledR}$ ). A fim de corrigir a angulação radicular dos primeiros molares superiores distalizados e evitar uma possível recidiva, recomendou-se o uso do aparelho extrabucal por um período de 12 horas por dia (Figura 4.17).

Para finalizar o tratamento, os pacientes foram encaminhados para a ortodontia corretiva com a finalidade de alinhar e nivelar os arcos dentários superior e inferior.

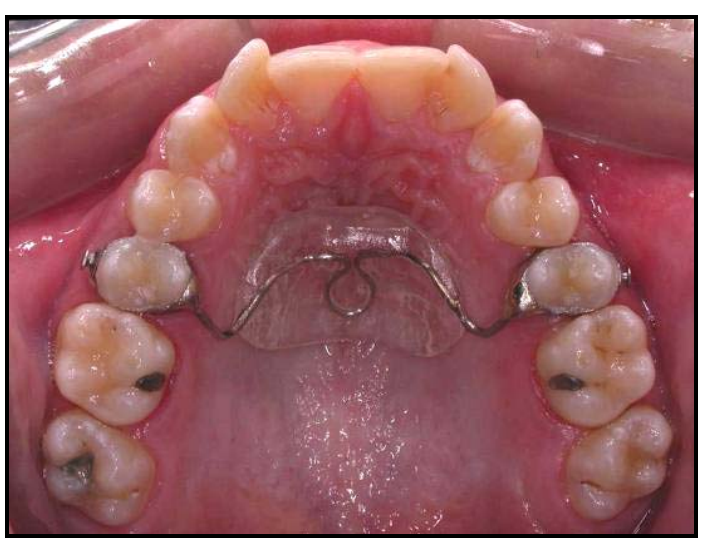

FIGURA 4.5 - Instalação botão de Nance modificado nos segundos pré-molares superiores

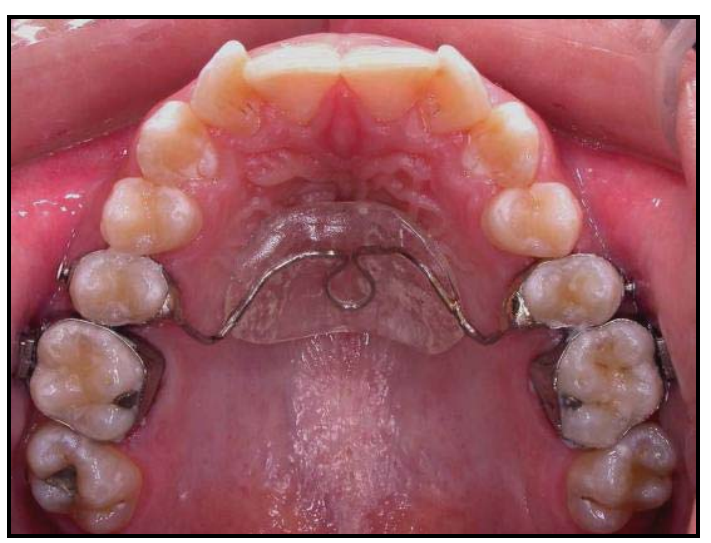

FIGURA 4.6 - Instalação das bandas nos primeiros molares superiores 


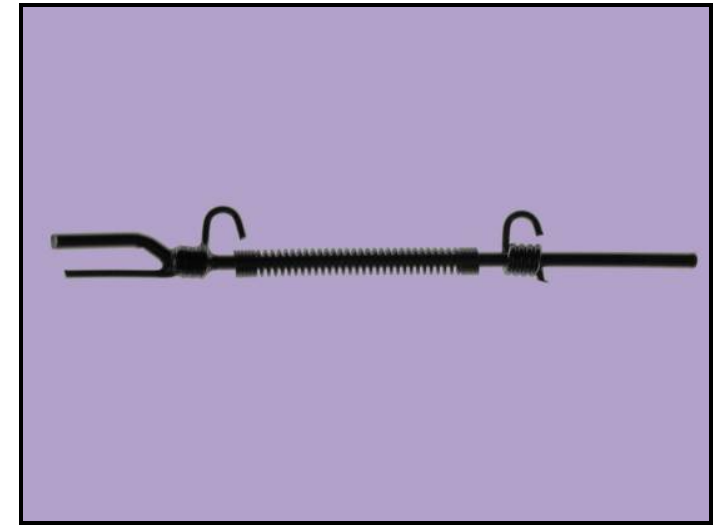

FIGURA 4.7 - Distalizador Jones jig Morelli $^{\circledR}$ - completo

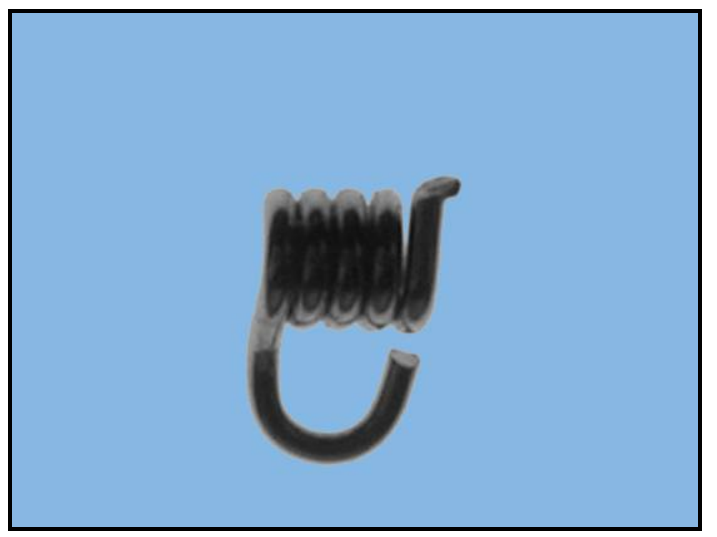

FIGURA 4.9 - Distalizador Jones jig Morelli $^{\circledR}$ - Cursor para compressão da mola

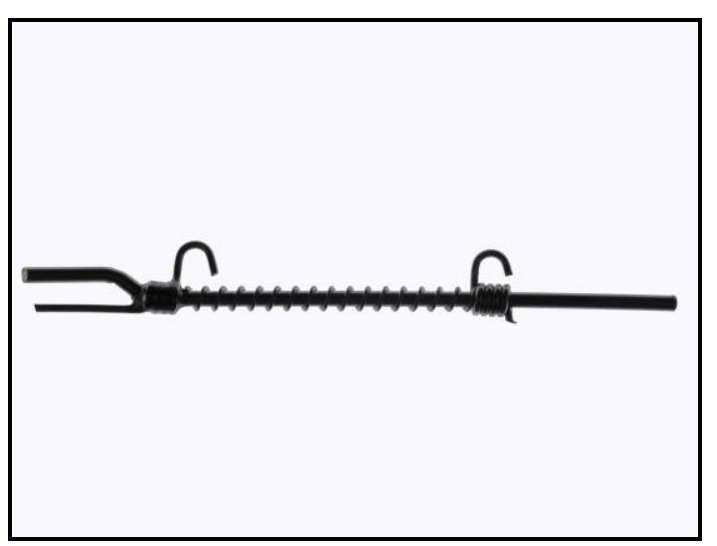

FIGURA 4.11 - Distalizador Jones jig modificado - corpo de aço e cursor Morelli ${ }^{\circledR}$ e mola secção aberta $\mathrm{GH}$

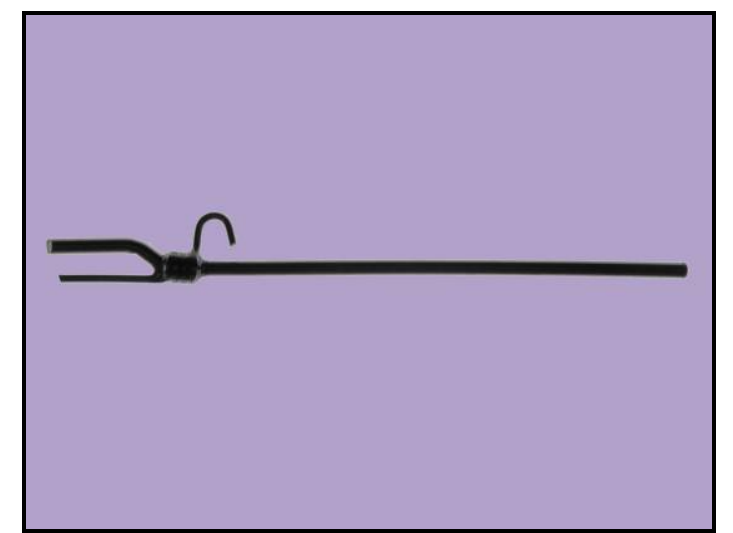

FIGURA 4.8 - Distalizador Jones jig Morelli $^{\circledR}$ - Corpo de aço .036"

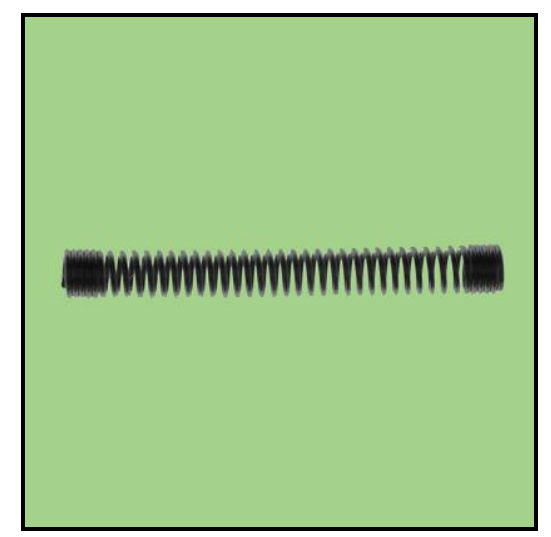

FIGURA 4.10 - Distalizador Jones jig Morelli $^{\circledR}$ - Mola de aço de secção aberta

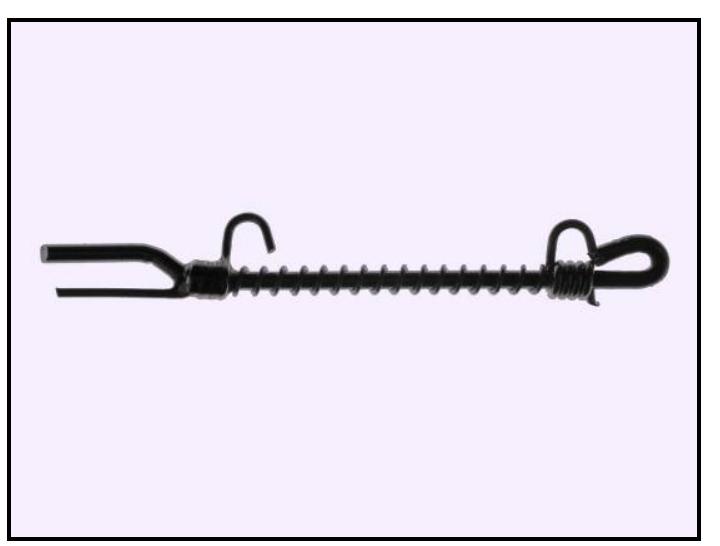

FIGURA 4.12 - Distalizador Jones jig modificado - pronto para instalação 

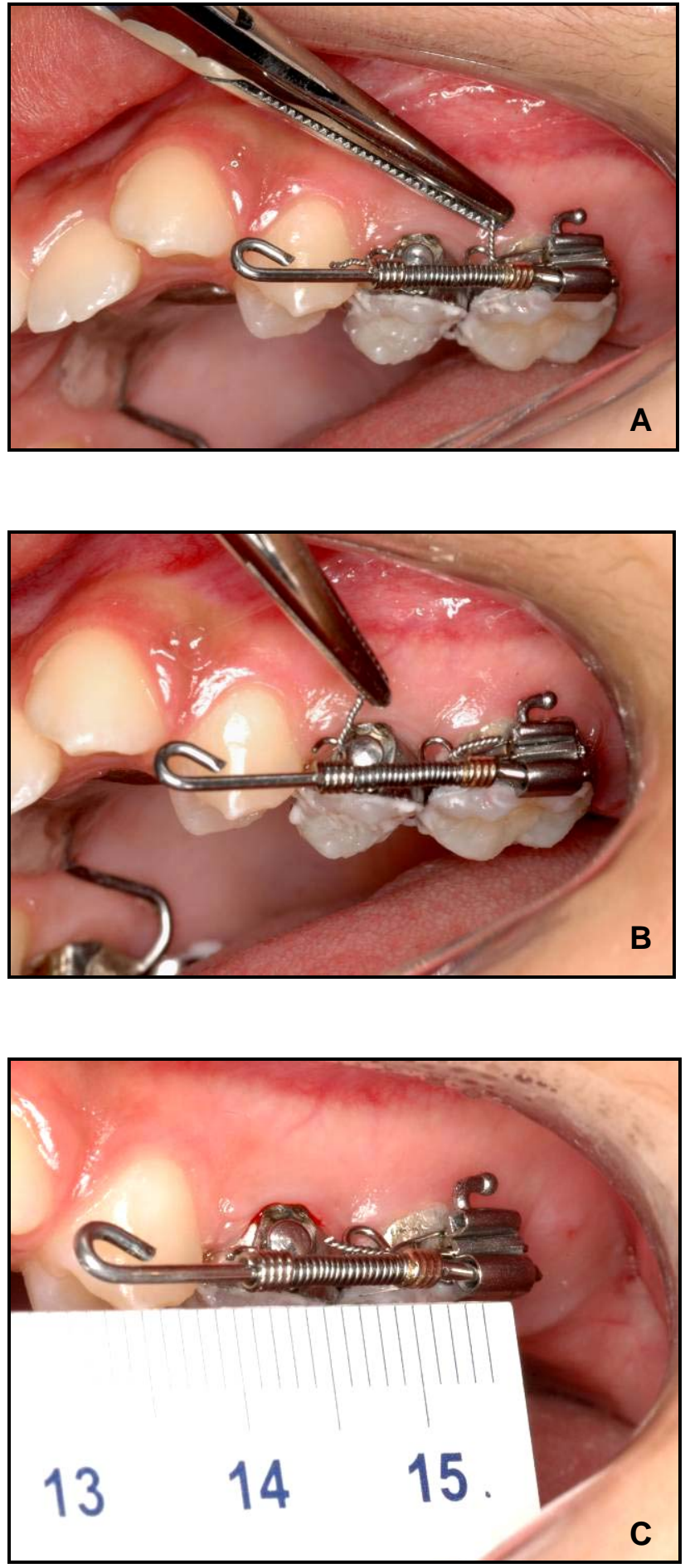

FIGURA 4.13 - Instalação dos distalizador Jones jig - amarrilho .012" para fixação no acessório da banda do primeiro molar (A) e no botão do segundo pré-molar superior (B); compressão de $5 \mathrm{~mm}$ da mola de NiTi (C) 

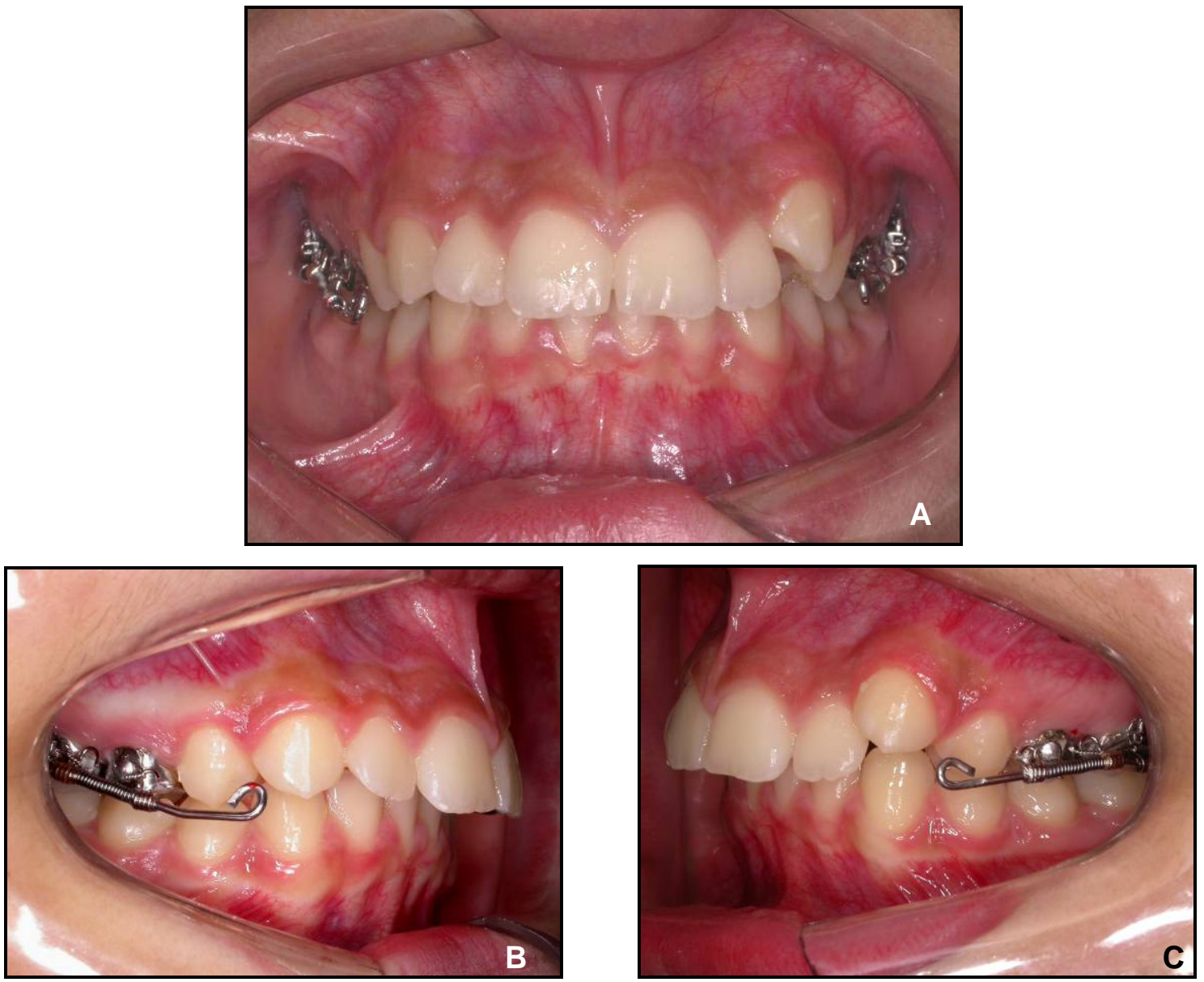

FIGURA 4.14 - Fotografias intrabucais frontal (A), lateral direita (B) e lateral esquerda (C) iniciais - Instalação do distalizador Jones jig
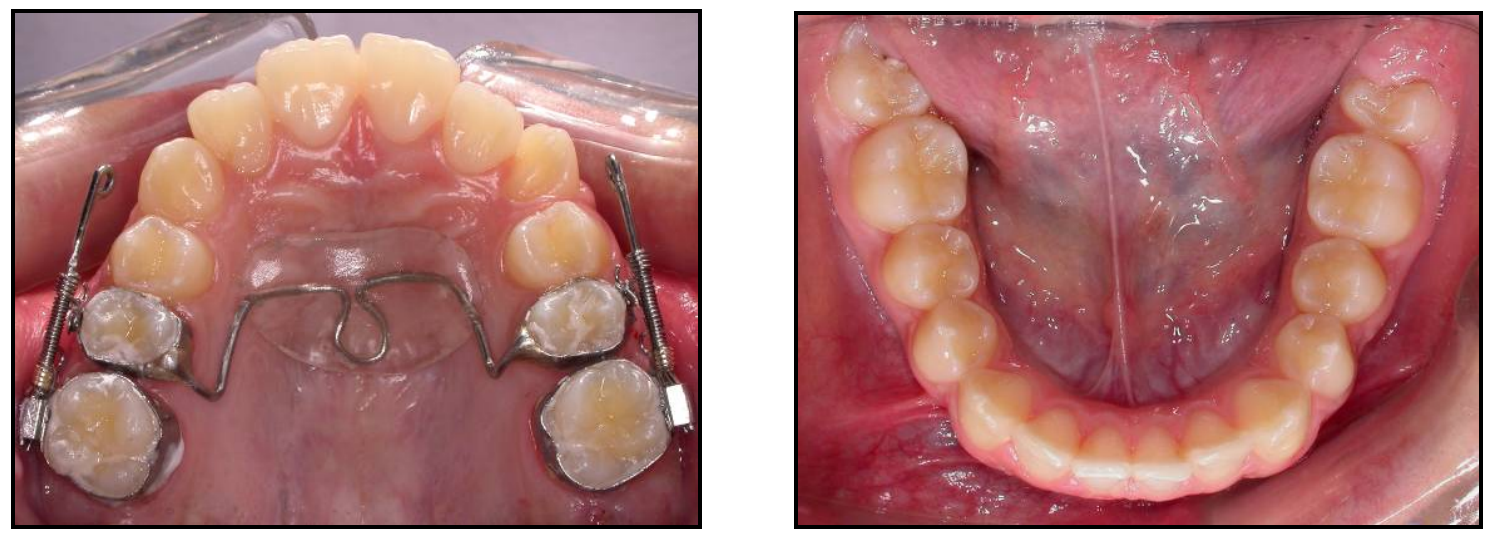

FIGURA 4.15 - Fotografias intrabucais iniciais oclusais superior e inferior Instalação do distalizador Jones jig 

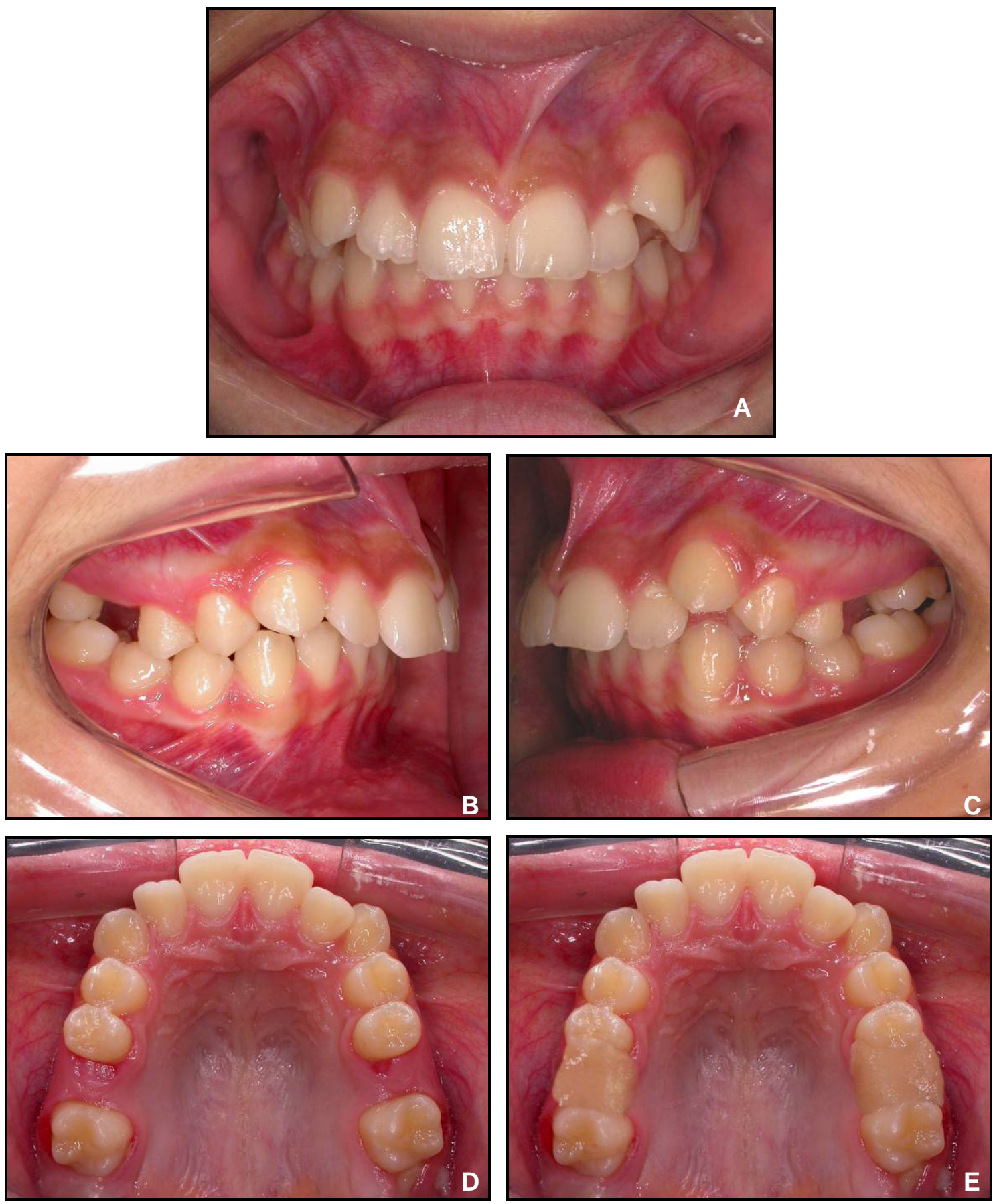

FIGURA 4.16 - Fotografias intrabucais frontal (A), laterais direita (B) e esquerda (C) e oclusal superior sem (D) e com (E) o bloco de acrílico para manutenção do espaço obtido após a distalização - Remoção do distalizador Jones jig 

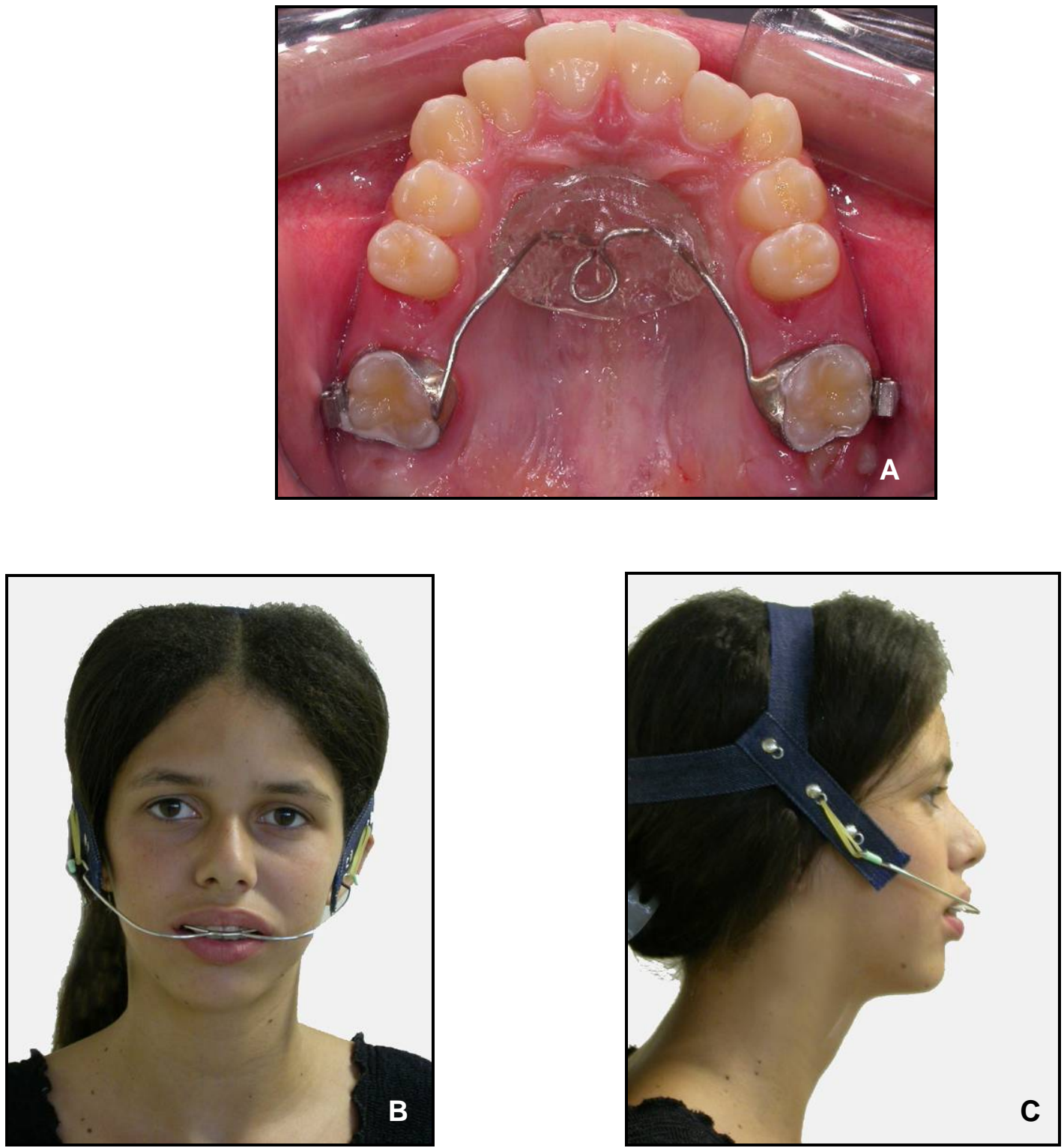

FIGURA 4.17 - Fotografia intrabucal oclusal superior com botão de Nance nos primeiros molares (A) - ancoragem intrabucal; fotografias extrabucais frontal $(B)$ e perfil (C) - ancoragem noturna, extrabucal tração média-alta (capacete jeans) 


\subsubsection{Obtenção das Telerradiografias em Norma Lateral}

As telerradiografias em norma lateral foram realizadas em aparelho radiográfico padrão com cefalostato, fonte de raios $X$ e filmes fixos com relação ao plano sagital do paciente. Para isso, foram utilizados filmes extrabucais TMAT, de dimensão $18 \times 24 \mathrm{~cm}$, da marca Kodak, chassi de metal, tamanho 20,8x26,8cm, equipado com écran intensificador Lanex Regular, os fatores de exposição foram 70-80Kvp, 8,0-10mA, com tempo de exposição conforme recomendado pelo fabricante.

O cefalostato empregado para o posicionamento da cabeça dos pacientes foi do tipo MARGOLIS. Baseando-se nas afirmações de FREITAS ${ }^{56}$, a distância foco-filme deve ser de 1,53m. A revelação da radiografia foi realizada por processamento automático através de aparelho competente. Como medida de proteção biológica, todas as exposições radiografias foram realizadas mediante o uso de colar e avental de chumbo por parte dos pacientes.

As telerradiografias foram obtidas ao início do tratamento e imediatamente após o período de distalização com o aparelho Jones jig (Figura 4.18).
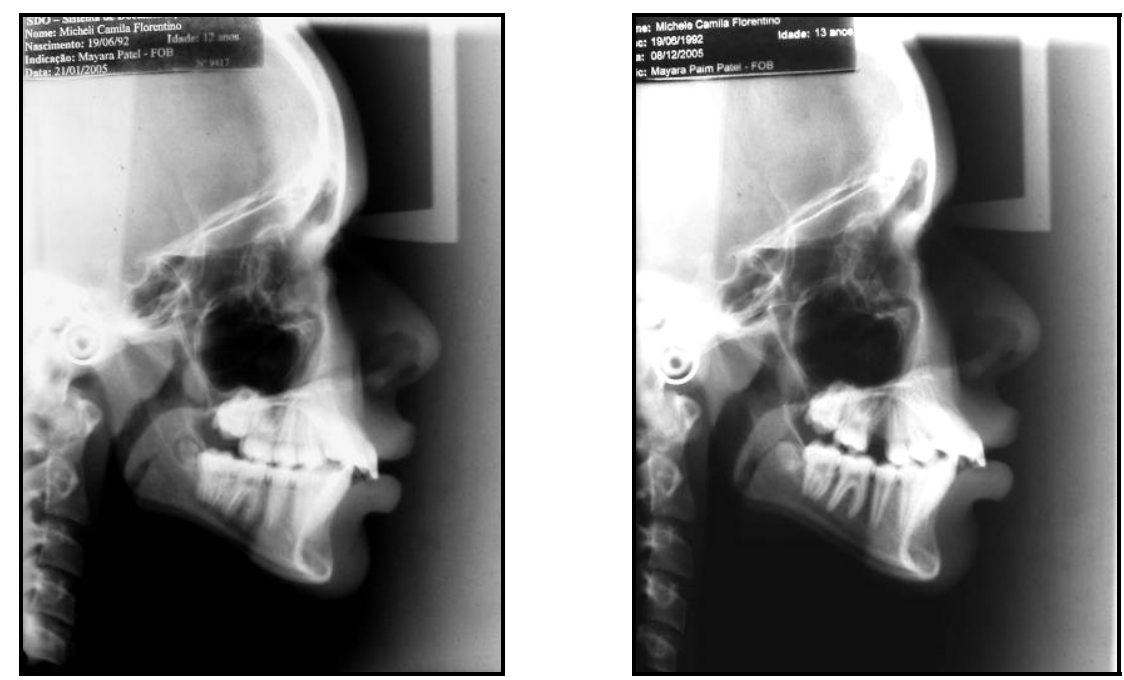

FIGURA 4.18 - Telerradiografias em norma lateral inicial e pós-distalização 


\subsubsection{Elaboração do Cefalograma da Telerradiografia em Norma Lateral}

Em cada telerradiografia adaptou-se uma folha de papel de acetato transparente "Ultraphan", da marca UNITEK/3M de dimensão $17,5 \mathrm{~cm}$ de largura por $17,5 \mathrm{~cm}$ de comprimento e espessura de 0,07mm. Em seguida, realizou-se o cefalograma sobre um negatoscópio, sempre pelo mesmo operador utilizando uma lapiseira e grafite $\mathrm{HB}$ 0,5mm e conferido pelo orientador da investigação. Para facilitar a visualização das estruturas em questão, esse procedimento foi realizado em sala obscurecida. Por meio de uma mesa digitalizadora Numonics A-30TL. $\mathrm{F}^{\mathrm{a}}$, acoplada a um microcomputador AMD K-6 I| 500MHz, transferiu-se a localização dos pontos dos cefalogramas para o programa de cefalometria Dentofacial Planner $7.02^{\mathrm{b}}$ onde foram processadas as mensurações envolvendo os planos e as linhas. Efetuou-se a correção da magnificação da imagem radiográfica, com 0 programa cefalométrico supracitado. Os fatores de magnificação foram determinados em $6 \%$ e $9,8 \%$.

A elaboração do cefalograma consistiu do desenho anatômico, dos pontos cefalométricos e das linhas e planos de referência.

\section{Desenho Anatômico}

O desenho anatômico constitui-se do contorno das linhas radiopacas das seguintes estruturas (Figura 4.19):

1. Perfil mole;

2. Base do crânio;

3. Asa maior do esfenóide;

4. Sela túrcica;

5. Perfil anterior do osso frontal e ossos próprios do nariz;

\footnotetext{
${ }^{a}$ Numonics Corporation, Montgomeryville, PA, EUA.

b Dentofacial Planner Software Inc., Toronto, Ontário, Canadá.
} 
6. Borda póstero-inferior das órbitas;

7. Fissura pterigomaxilar;

8. Meato acústico externo;

9. Maxila: linha do assoalho da fossa nasal, espinha nasal anterior e posterior, rebordo alveolar anterior e palato ósseo;

10. Mandíbula: rebordo alveolar anterior, cortical externa na região da sínfise, borda inferior do corpo mandibular, borda posterior do ramo e processo condilar;

11. Segundos molares permanentes superiores,

12. Primeiros molares permanentes superiores;

13. Segundos pré-molares superiores;

14. Incisivos centrais permanentes superiores;

15. Primeiros molares permanentes inferiores;

16. Incisivos centrais permanentes inferiores.

As estruturas simétricas, que, portanto apresentarão imagem duplicada, foram traçadas a partir de uma média das mesmas para se aproximar à magnificação do plano sagital mediano ${ }^{144}$. 


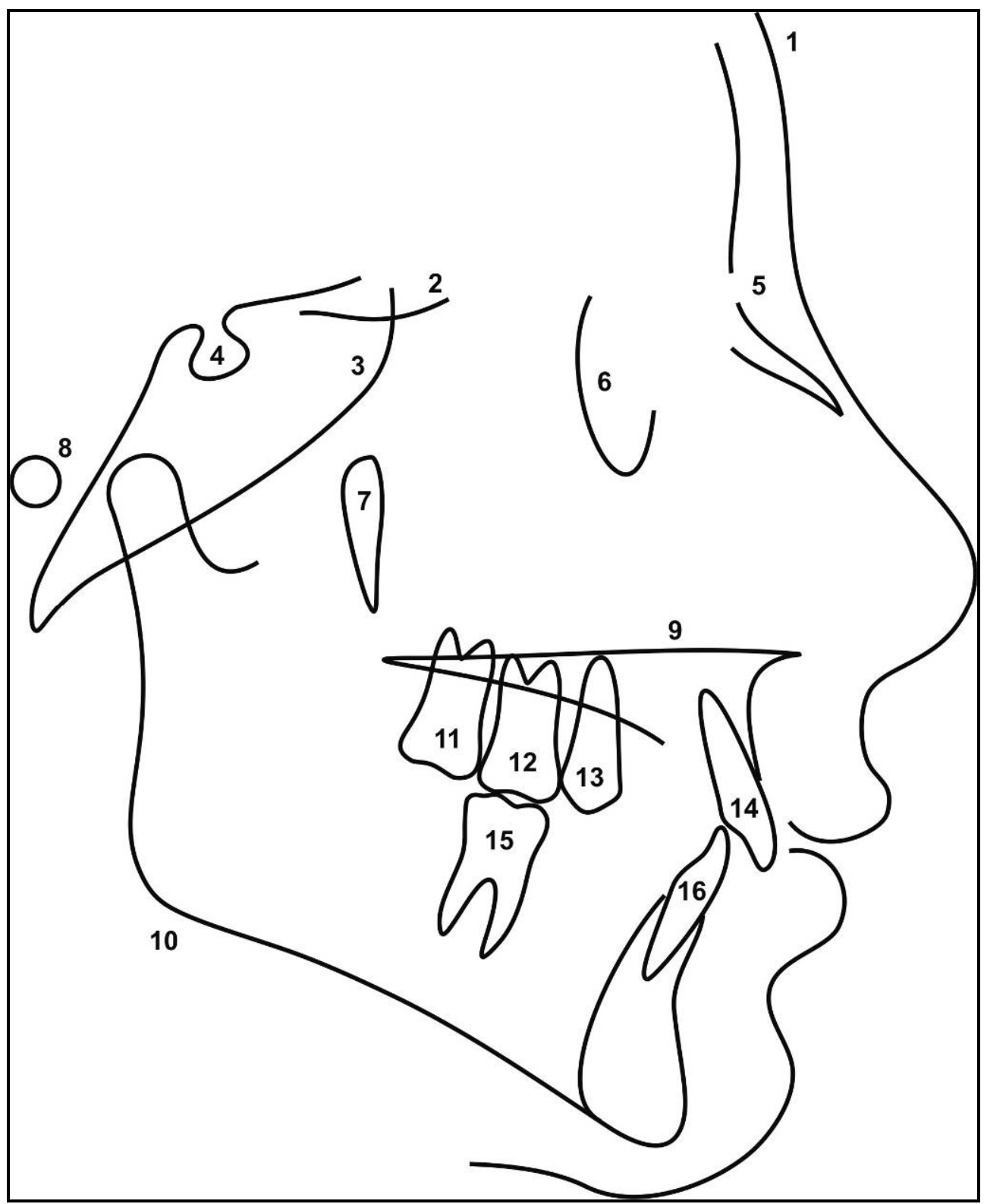

FIGURA 4.19 - Desenho anatômico

\section{Definição dos Pontos Cefalométricos (Figura 4.20):}

Os pontos cefalométricos seguindo as especificações de Krogman; Sassouni ${ }^{109}$, Riolo ${ }^{139}$, McNamara ${ }^{119}$, Jacobson ${ }^{89}$, Legan $^{110}$, Ghosh $^{60}$ e Steiner $^{156}$ e de interesse para as análises foram os seguintes:

1. S (sela túrcica) - ponto mais central da sela túrcica;

2. $\mathrm{N}$ (násio) - ponto mais anterior da sutura frontonasal; 
3. Or (orbitário): a média dos pontos mais inferiores das margens inferiores das órbitas;

4. ENA (espinha nasal anterior) - ponto mais anterior da espinha nasal anterior;

5. ENP (espinha nasal posterior) - ponto mais posterior do assoalho da fossa nasal;

6. Ponto A (subespinhal): ponto mais profundo da concavidade da pré-maxila, entre a espinha nasal anterior e próstio;

7. Ponto B (supramentoniano): ponto mais profundo da concavidade da sínfise mentoniana, entre o pogônio e o infradentário;

8. Gn (gnátio): ponto mais inferior e anterior do contorno do mento ósseo, definido pela bissetriz das linhas NPog e o plano mandibular (GoMe);

9. Me (mentoniano): ponto médio mais inferior da sínfise mentoniana;

10.Go (gônio): ponto mais posterior e inferior da curvatura entre o corpo e o ramo da mandíbula, definido pela bissetriz do ângulo formado pela tangente à borda inferior do corpo da mandíbula e outra tangente à borda posterior do ramo ascendente da mandíbula;

11. Po (pório anatômico): ponto mais superior do meato acústico externo;

12. RE (ponto do registro esfenoidal): intersecção do plano esfenoidal com ossos maiores dos esfenóides;

13. PTMI (pterigomaxilar inferior): o ponto mais inferior na média das linhas externa direita e esquerda da fissura pterigomaxilar;

14. BIS (borda incisal superior): ponto mais inferior da borda incisal do incisivo central superior;

15. AIS (ápice incisal superior): ponto mais superior do ápice radicular do incisivo central superior;

16. BII (borda do incisivo inferior): ponto mais superior da borda do incisivo central inferior;

17. Centro $\underline{5}$ : ponto médio da linha que une a maior convexidade mesial e distal do segundo pré-molar superior $23,25,26,60,126,143$; 
18. Centro $\underline{6}$ : ponto médio da linha que une a maior convexidade mesial e distal do primeiro molar superior ${ }^{23,25,26,60,126,143 ;}$

19. Centro $\underline{7}$ : ponto médio da linha que une a maior convexidade mesial e distal do segundo molar superior ${ }^{23,25,26,60,126,143}$;

20. Ponto localizado na intersecção radicular do segundo molar superior indicando o longo eixo desse dente;

21. Ponto localizado na intersecção radicular do primeiro molar superior indicando o longo eixo desse dente;

22. Ápice radicular do segundo pré-molar superior: ponto do ápice radicular do segundo pré-molar superior;

23. $\operatorname{Pr}$ (Pronasal): ponto mais anterior do nariz

24. Cn (Columela Nasal): ponto mais inferior do nariz;

25. Sn (Subnasal): ponto em que a columela se intersecta com o lábio superior no plano médio sagital;

26. Ls (lábio superior): ponto na região mais anterior do lábio superior;

27. Li (lábio inferior): ponto na região mais anterior do lábio inferior;

28. Pog' (pogônio mole): ponto mais anterior do contorno do mento mole

Como forma de padronização no momento de registrar o ponto central da coroa dos segundos e primeiros molares e segundos pré-molares superiores, foi realizado um traçado médio desses dentes, considerando a sobreposição de imagens (direita e esquerda). A partir do desenho médio dessas estruturas, foi determinado um ponto médio na maior convexidade mesiodistal de cada coroa dentária.

Com o intuito de facilitar a demarcação dos pontos e a digitalização dos mesmos, cada ponto foi identificado por meio de duas linhas de referência, uma horizontal e outra vertical, sendo que o referido ponto cefalométrico se localizaria na intersecção dessas linhas. O cursor de digitalização foi posicionado de maneira a enquadrar corretamente essas referências durante o procedimento de digitalização. 


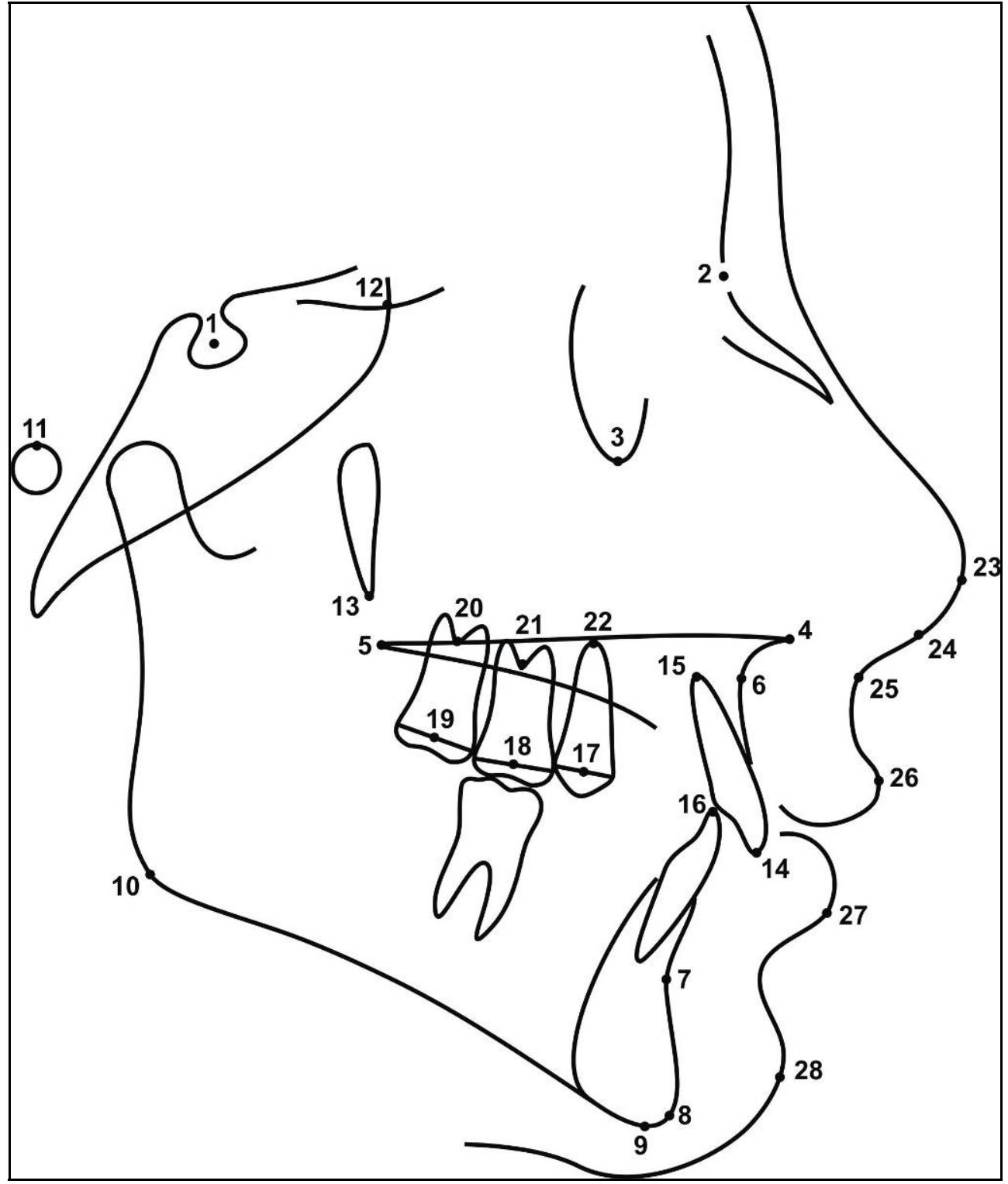

4.20 - Pontos cefalométricos

\section{Linhas e Planos (Figura 4.21):}

As linhas e planos de referência utilizados seguiram as especificações de Brickman, Sinha, Nanda ${ }^{23}$ e Runge; Martin; Bukai ${ }^{143}$ :

A. Plano E (plano estético): tangente entre o ponto mais anterior do nariz (pronasal) e do mento mole (pogônio mole - Pog'); 
B. Plano horizontal de Frankfurt: é o ponto que une os pontos pório (Po) e orbitário (Or);

C. PP (Plano Palatino): plano que une os pontos espinha nasal anterior (ENA) e espinha nasal posterior (ENP);

D. GoMe (Plano Mandibular): plano que une os pontos gônio (Go) e mentoniano (Me);

E. GoGn (Plano Mandibular): é a representação da base mandibular por meio da uma linha que passa pelos pontos gônio (Go) e gnátio (Gn);

F. Linha Vertical Pterigomaxilar ${ }^{48}$ : passa pela intersecção do plano esfenoidal com as asas maiores dos esfenóides ao ponto mais inferior da fissura pterigomaxilar.

G. Linha SN: linha que passa pelos pontos sela (S) e násio (N);

H. Linha SGn: ( Eixo Y de Crescimento): linha que une os pontos S e Gn;

I. Linha que une os pontos espinha nasal anterior (ENA) e mentoniano (Me);

J. Linha que se estende do ponto pronasal (Pr) ao ponto subnasal $(\mathrm{Sn})$ passando pela columela nasal $(\mathrm{Cn})$;

K. Linha que se estende do subnasal (Sn) ao ponto do lábio superior (Ls);

L. Linha do longo eixo do incisivo central: linha que passa pelo ápice (AIS) e pela borda incisal do incisivo central superior (BIs);

M. Linha do longo eixo do segundo pré-molar superior: perpendicular à linha que une a maior convexidade mesial e distal do segundo prémolar superior no ponto do centro da coroa (Centro $\underline{5}^{23,25,26,60,126,143 \text {; }}$

N. Linha do longo eixo do primeiro molar superior: perpendicular à linha que une a maior convexidade mesial e distal do primeiro molar superior, passando pelo ponto do centro da coroa (Centro 6) $23,25,26,60,126,143$;

O. Linha do longo eixo do segundo molar superior: perpendicular à linha que une a maior convexidade mesial e distal do segundo 
molar superior, passando pelo ponto do centro da coroa (Centro 7) $23,25,26,60,126,143$;

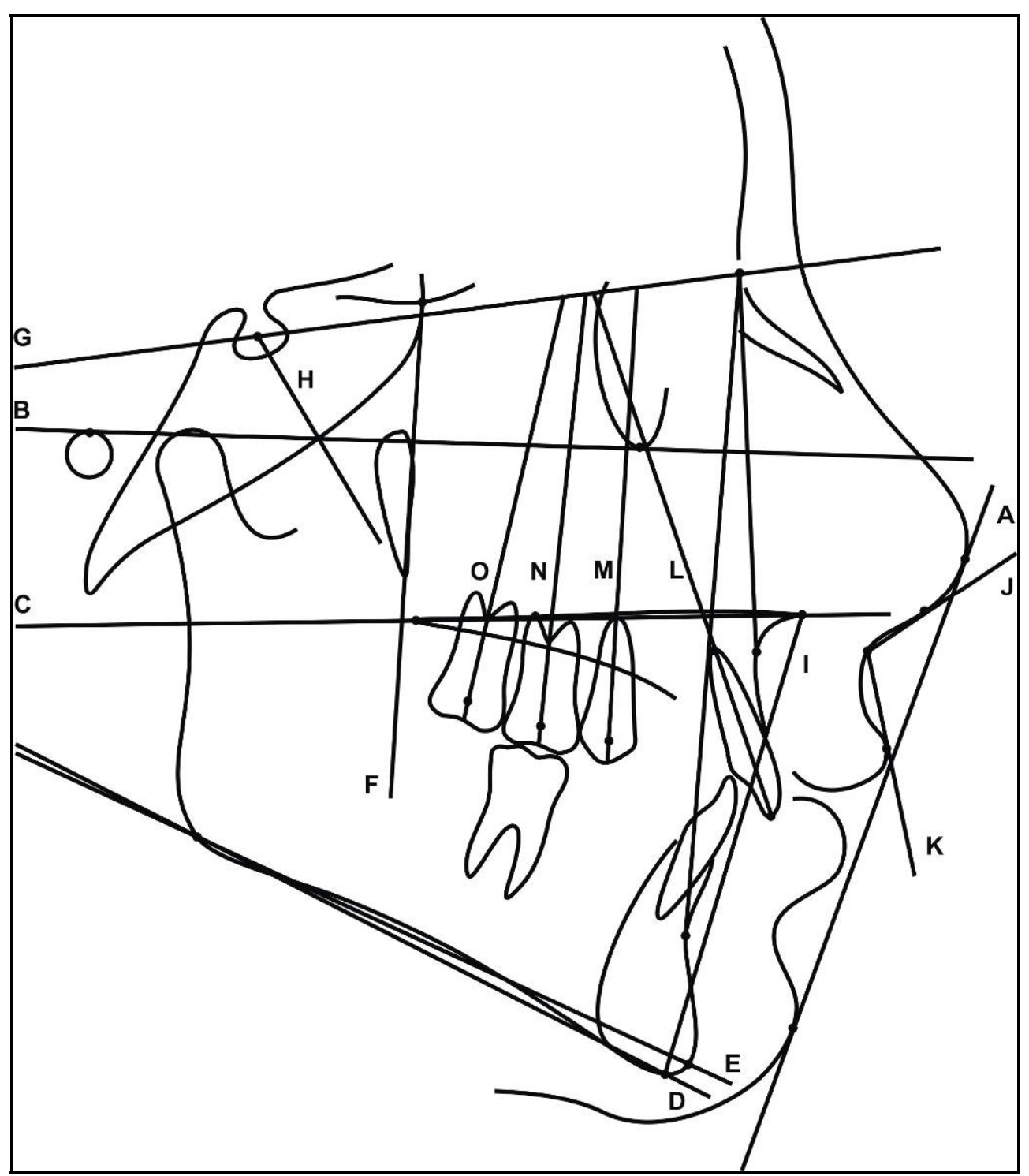

FIGURA 4.21 - Linhas e planos cefalométricos 


\section{$>$ Grandezas angulares e lineares do padrão facial (Figura 4.22):}

Ângulo FMA: Plano Horizontal de Frankfurt ao Plano Mentoniano (GoMe). Se o valor ultrapassar a norma $\left(25^{\circ}\right)$, demonstra uma tendência de crescimento vertical; caso contrário, se o valor estiver abaixo da norma, demonstra uma tendência de padrão horizontal de crescimento;

AFAl: altura facial ântero-inferior; é a medida linear entre os pontos espinha nasal anterior e o mentoniano (ENA - Me). Determina o padrão do esqueleto facial, isto é, predominância do crescimento vertical ou horizontal. Identifica a presença ou não de rotação mandibular nos sentido horário ou antihorário.

Ângulo SN.GoGn: permite avaliar o comportamento da base do crânio (SN) em relação à base mandibular (GoGn). Valores acima da norma $\left(32^{\circ}\right)$ mostram que há uma divergência dos planos horizontais, com predominância do crescimento craniofacial no sentido vertical. Contudo, valores abaixo da norma determinam um crescimento preponderante no sentido horizontal.

Ângulo NS.Gn (eixo Y de crescimento): determinado pelas linhas SN e SGn. Também denominado "eixo $Y$ de crescimento". Define a resultante vetorial de crescimento ântero-inferior da mandíbula. Valores acima da norma $\left(67^{\circ}\right)$ representam um vetor de crescimento facial no sentido vertical enquanto que os valores abaixo, um vetor de crescimento facial no sentido horizontal.

\section{Grandezas lineares esqueléticas:}

PTV - A: distância do ponto A à linha vertical pterigomaxilar; demonstra o posicionamento maxilar no sentido sagital em relação à linha vertical pterigomaxilar; 
PTV - B: distância do ponto B à linha vertical pterigomaxilar; demonstra o posicionamento mandibular no sentido sagital em relação à linha vertical pterigomaxilar;

\section{Grandezas Angulares Esqueléticas:}

Ângulo SNA: avalia a posição ântero-posterior da maxila, e expressa o grau de protrusão ou retrusão da maxila em relação à base do crânio; apresenta como referência maxilar o ponto $A$.

Ângulo SNB: determina a posição ântero-posterior da mandíbula, representada pelo ponto $\mathrm{B}$, em relação à base do crânio. Os valores obtidos expressam a protrusão ou retrusão mandibular.

Ângulo ANB: determinado pela diferença matemática entre os ângulos SNA e SNB, revelando a relação ântero-posterior entre a maxila e a mandíbula. Os valores entre 0 e 4,5 indicam uma provável relação de Classe I, enquanto que valores acima de 4,5, um provável relacionamento de Classe II, ao passo que um ANB negativo sinaliza uma Classe III.

\section{$>$ Grandezas Tegumentares:}

Plano E - Ls (mm): distância linear entre o lábio superior (Ls) e o Plano E. Indica a protrusão ou retrusão do lábio superior;

Plano E - Li (mm): distância linear entre o lábio inferior (Li) e o Plano E. Indica a protrusão ou retrusão do lábio inferior;

Ângulo Nasolabial: determinado pelo ângulo formado entre a linha que une os pontos subnasal (Sn) e columela nasal (Cn) e outra que se estende do ponto 
subnasal ao lábio superior (Ls). Um ângulo diminuído representa uma protrusão dentoalveolar superior e um ângulo aumentado, uma retrusão dentoalveolar superior.

\section{Grandezas Dentárias Angulares e Lineares:}

\section{- Grandezas Dentárias Angulares (Figura 4.23):}

SN.1: Linha SN ao incisivo superior; ângulo formado pelo longo eixo do incisivo central superior à base do crânio, representada pela linha SN. Essa grandeza é determinada em relação ao valor inicial e ao valor pós-distalização, indicando se realmente a distalização provoca inclinação dos dentes anteriores;

SN.5: Linha SN ao segundo pré-molar superior; ângulo formado pelo longo eixo do segundo pré-molar superior à base do crânio, representada pela linha SN. Essa grandeza é determinada em relação ao valor inicial e ao valor pós-distalização, indicando se a distalização provoca angulação mesial dos dentes de ancoragem;

SN.6: Linha SN ao primeiro molar superior; ângulo formado pelo longo eixo do primeiro molar superior à base do crânio, representada pela linha SN. Essa grandeza é determinada em relação ao valor inicial e ao valor pósdistalização, indicando se a distalização ocorre à base da angulação dos molares superiores;

SN.7: Linha SN ao segundo molar superior; ângulo formado pelo longo eixo do segundo molar superior à base do crânio, representada pela linha SN. Essa grandeza é determinada em relação ao valor inicial e ao valor pósdistalização, indicando se a distalização ocorre à base da angulação dos molares superiores; 


\section{- Grandezas Dentárias Lineares (Figura 4.24):}

PTV - 1: linha PTV à incisal do incisivo central superior; distância da base incisal do incisivo central superior (Bis) à linha vertical pterigomaxilar. Indica a posição ântero-posterior do incisivo central superior. A interpretação dessa grandeza é obtida por meio da comparação dos valores inicias e pósdistalização. Por exemplo, se o valor final for maior que o valor inicial, demonstra que os incisivos superiores se movimentam para anterior em decorrência da força de distalização;

PTV - 5: linha PTV ao centro do segundo pré-molar superior; distância do ponto do centro da coroa do segundo pré-molar superior (Centro 5) à linha vertical pterigomaxilar. Indica a posição ântero-posterior do segundo pré-molar superior. É definido pela comparação entre os valores iniciais e pósdistalização. Valores finais maiores que os iniciais demonstram uma mesialização dos pré-molares, isto é, perda de ancoragem;

PTV - 6: linha PTV ao centro do primeiro molar superior; distância do ponto do centro da coroa do primeiro molar superior (Centro 6) à linha vertical pterigomaxilar. Indica a posição ântero-posterior do primeiro molar superior. É definido pela comparação entre os valores iniciais e pós-distalização. Valores finais menores indicam a quantidade de distalização primeiros molares superiores;

PTV - 7: linha PTV ao centro do segundo molar superior; distância do ponto do centro da coroa do segundo molar superior (Centro 7) à linha vertical pterigomaxilar. Indica a posição ântero-posterior do segundo molar superior. É definido pela comparação entre os valores iniciais e pós-distalização. Valores finais menores indicam a quantidade de distalização primeiros molares superiores;

PP - 1: plano palatino a incisal do incisivo central superior; distância linear vertical entre o plano palatino $(P P)$ e a base incisal do incisivo central 
superior (BIs); permite avaliar se durante o processo de distalização ocorreu intrusão ou extrusão do incisivo central superior;

PP - 5: plano palatino ao centro do segundo pré-molar superior; distância linear vertical entre o plano palatino (PP) e o ponto do centro da coroa do segundo pré-molar superior (Centro 5); demonstra o grau de intrusão ou extrusão do segundo pré-molar superior durante o movimento de distalização;

PP - 6: plano palatino ao centro do primeiro molar superior; distância linear vertical entre o plano palatino (PP) e o ponto do centro da coroa do primeiro molar superior (Centro 6); determina a quantidade de intrusão ou extrusão do primeiro molar superior durante a distalização;

PP - 7: plano palatino ao centro do segundo molar superior; distância linear vertical entre o plano palatino $(\mathrm{PP})$ e o ponto do centro da coroa do segundo molar superior (Centro 7); determina a quantidade de intrusão ou extrusão do segundo molar superior durante a distalização;

Trespasse Horizontal: linha horizontal da incisal do incisivo central superior ao inferior; avalia se durante a fase de distalização ocorreu alteração entre incisivos superiores e inferiores quanto ao posicionamento ânteroposterior;

Trespasse Vertical: linha vertical da incisal do incisivo central superior ao inferior; avalia se durante a fase de distalização ocorreu alteração entre incisivos superiores e inferiores quanto ao posicionamento vertical; 


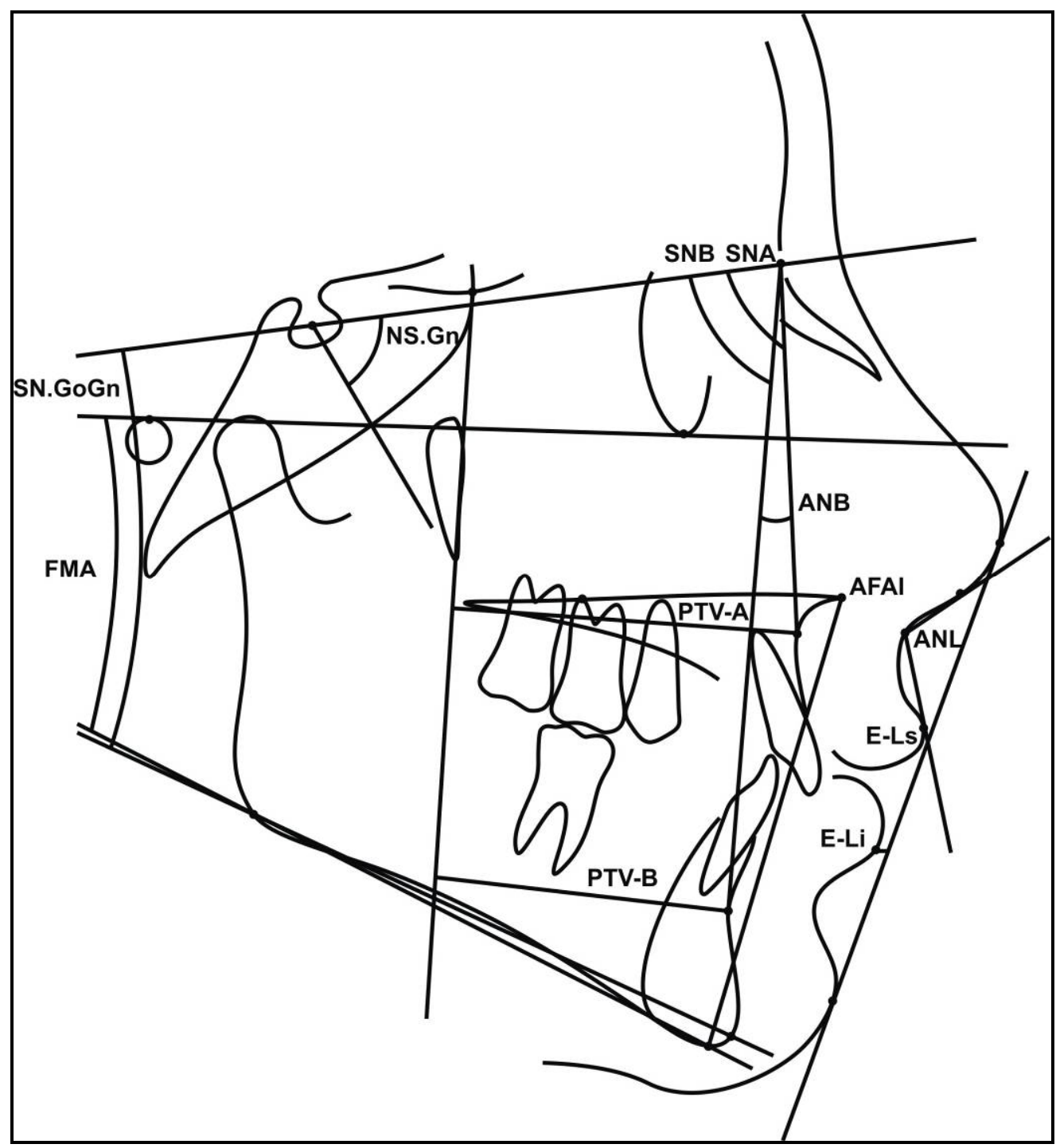

FIGURA 4.22 - Medidas cefalométricas do tecido mole e esquelético 


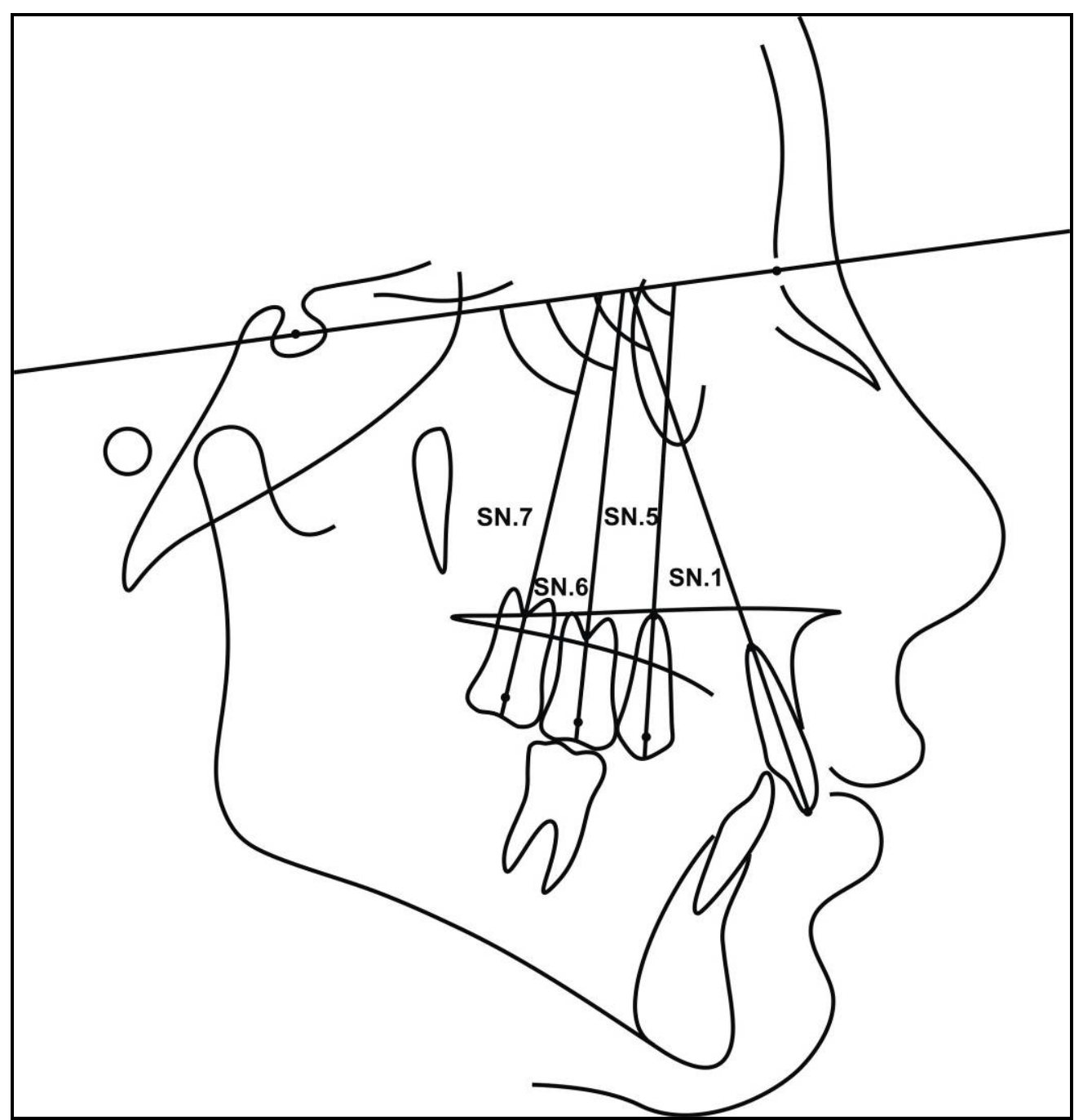

FIGURA 4.23 - Medidas dentárias angulares 


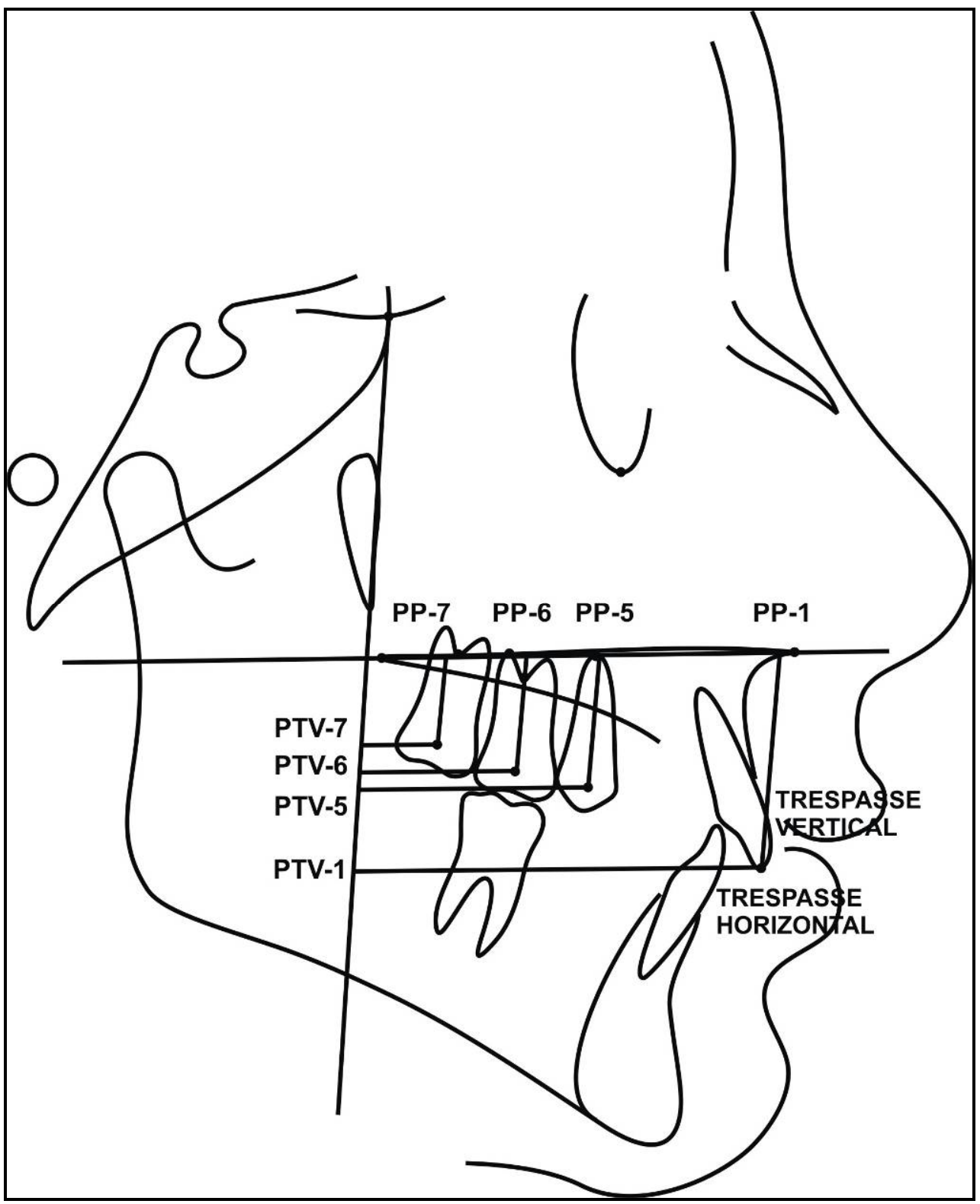

FIGURA 4.24 - Medidas dentárias lineares 


\subsubsection{Análise do Erro Metodológico}

Para analisar o erro metodológico, as telerradiografias em norma lateral inicial e pós-distalização de 10 pacientes foram selecionadas aleatoriamente e 20 telerradiografias foram novamente traçadas após o período de 15 dias. Os critérios pré-estabelecidos foram rigorosamente seguidos, em busca de uma padronização. Formaram-se assim dois grupos: um constando dos traçados realizados inicialmente (inicial e pós-distalização), comparados com os traçados (inicial e pós-distalização) confeccionados novamente após 2 semanas; apresentando portanto dois tempos distintos. Os dados foram dispostos em tabelas do programa Excel e encaminhados para a análise estatística para a verificação do erro sistemático e casual intra-examinador.

\section{$>$ Erro Casual}

O erro casual transcreve a demarcação de pontos cefalométricos ou do próprio traçado em locais diferentes entre um traçado e outro. É determinado pelo teste do erro de Dahlberg ${ }^{43}$, definido pela fórmula:

$$
E 2=\frac{\Sigma d 2}{2 n}
$$

Sendo, "d" = diferença entre as mensurações de uma mesma variável.

"n" = número de pares de cefalogramas comparados.

\section{Erro Sistemático}

Calculou-se o erro sistemático do método por meio da aplicação do teste $t$ pareado $^{85}$, ao nível de significância de 5\%, comparando-se as leituras iniciais e as repetições das 20 telerradiografias selecionadas aleatoriamente. Valores de $p$ menores que 0,05 , traduzem diferenças estatisticamente significantes para um nível de significância de 5\%. 


\subsubsection{Análise Estatística dos Resultados}

A análise estatística objetivou avaliar as alterações dentárias e esqueléticas ocorridas a partir da utilização dos distalizador Jones jig, cuja finalidade corresponde a corrigir a relação molar inicial de Classe II. Portanto, com o intuito descritivo, analisaram-se as alterações ocorridas em pacientes de um mesmo grupo. Sendo assim, empregou o teste $t$ de Student pareado para realização da análise intragrupo, que verificou as variações de um mesmo paciente nas fases pré e pós distalização. O valor crítico foi considerado ao nível de significância de 0,05 para todas as análises realizadas.

O teste estatístico de correlação de Pearson ("r") foi realizado para verificar a existência de alguma correlação entre as grandezas lineares e angulares dentárias quanto às alterações no padrão facial de crescimento, nos componentes esqueléticos e no perfil tegumentar.

Todos os testes foram realizados a partir do programa Statistica for Windows $6.0^{c}$ adotando um nível de significância de $5 \%$, ou seja, considerando 95\% dos resultados.

c STATISTICA for Windows. StatSoft, Inc. (1995). Tulsa, OK, EUA. 


$$
\text { IResulterdos }
$$





\section{RESULTADOS}

\section{Erro do Método}

Os valores da $1^{\mathrm{a}}$ e da $2^{\mathrm{a}}$ medições de 20 telerradiografias estão representados na tabela 2 , com os respectivos resultados do erro casual (Dahlberg) e do erro sistemático ( $t$ pareado):

TABELA 2 - Resultado do teste $t$ de Student para dados pareados e Dahlberg para análise do erro metodológico

\begin{tabular}{|c|c|c|c|c|c|c|c|}
\hline \multirow[b]{2}{*}{ VARIÁVEIS } & \multirow[b]{2}{*}{$N$} & \multicolumn{2}{|c|}{$1^{a}$ MEDIÇÃO } & \multicolumn{2}{|c|}{$2^{a}$ MEDIÇÃO } & \multirow[b]{2}{*}{ ERRO } & \multirow[b]{2}{*}{$p$} \\
\hline & & MÉDIA & $D P$ & MÉDIA & $D P$ & & \\
\hline
\end{tabular}

COMPONENTES DENTOALVEOLARES ANGULAR E LINEAR

\begin{tabular}{c|c|c|c|c|c|c|c}
\hline SN.7 & 20 & 63,190 & 5,539 & 63,845 & 4,759 & 1,173 & 0,077 \\
\hline SN.6 & 20 & 74,770 & 6,863 & 75,475 & 7,221 & 1,206 & 0,062 \\
\hline SN.5 & 20 & 85,805 & 5,764 & 86,995 & 5,854 & 1,203 & 0,126 \\
\hline SN.1 & 20 & 105,315 & 10,996 & 105,905 & 9,088 & 1,369 & 0,822 \\
\hline PTV-7 & 20 & 12,060 & 2,812 & 11,925 & 2,409 & 0,987 & 0,677 \\
\hline PTV-6 & 20 & 21,165 & 3,140 & 20,995 & 2,913 & 0,912 & 0,569 \\
\hline PTV-5 & 20 & 31,565 & 3,971 & 31,920 & 4,301 & 0,941 & 0,243 \\
\hline PTV-1 & 20 & 55,915 & 5,344 & 56,550 & 5,438 & 0,805 & 0,062 \\
\hline PP-7 & 20 & 12,170 & 3,907 & 12,320 & 3,768 & 0,809 & 0,571 \\
\hline PP-6 & 20 & 17,180 & 2,168 & 17,485 & 2,192 & 0,561 & 0,085 \\
\hline PP-5 & 20 & 20,050 & 2,235 & 19,795 & 2,273 & 0,506 & 0,113 \\
\hline PP-1 & 20 & 26,930 & 2,590 & 27,180 & 2,766 & 0,670 & 0,110 \\
\hline $\begin{array}{c}\text { TRESPASSE } \\
\text { HORIZONTAL }\end{array}$ & 20 & 4,835 & 1,959 & 4,860 & 1,819 & 0,456 & 0,867 \\
\hline $\begin{array}{c}\text { TRESPASSE } \\
\text { VERTICAL }\end{array}$ & 20 & 3,705 & 1,712 & 4,000 & 1,689 & 0,501 & 0,060 \\
\hline
\end{tabular}

Continua... 
Continuação...

\begin{tabular}{|c|c|c|c|c|c|c|c|}
\hline \multirow[b]{2}{*}{ VARIÁVEIS } & \multirow[b]{2}{*}{$N$} & \multicolumn{2}{|c|}{$1^{a}$ MEDIÇÃO } & \multicolumn{2}{|c|}{$2^{a}$ MEDIÇÃO } & \multirow[b]{2}{*}{ ERRO } & \multirow[b]{2}{*}{$p$} \\
\hline & & MÉDIA & $D P$ & MÉDIA & $D P$ & & \\
\hline
\end{tabular}

COMPONENTES ESQUELÉTICOS ANGULARES E LINEARES

\begin{tabular}{c|c|c|c|c|c|c|c}
\hline SNA & 20 & 82,800 & 3,943 & 83,025 & 3,975 & 1,04 & 0,206 \\
\hline SNB & 20 & 78,760 & 3,579 & 79,620 & 3,292 & 0,979 & $\mathbf{0 , 0 0 3 ^ { * }}$ \\
\hline ANB & 20 & 4,060 & 1,850 & 3,865 & 1,590 & 0,434 & 0,161 \\
\hline PTV-A & 20 & 48,565 & 3,794 & 48,705 & 3,838 & 0,560 & 0,444 \\
\hline PTV-B & 20 & 46,770 & 4,821 & 47,690 & 4,893 & 0,804 & $\mathbf{0 , 0 2 7}$ \\
\hline
\end{tabular}

PADRÃO DE CRESCIMENTO

\begin{tabular}{c|c|c|c|c|c|c|c}
\hline FMA & 20 & 26,785 & 5,779 & 26,885 & 5,078 & 0,905 & 0,736 \\
\hline SN.GoGn & 20 & 32,235 & 5,386 & 31,690 & 5,106 & 1,417 & 0,077 \\
\hline NS.Gn & 20 & 59,555 & 5,207 & 59,330 & 5,117 & 0,605 & 0,250 \\
\hline AFAI & 20 & 62,650 & 5,727 & 62,870 & 5,698 & 0,455 & 0,129 \\
\hline
\end{tabular}

PERFIL TEGUMENTAR

\begin{tabular}{c|c|c|c|c|c|c|c}
\hline ANL & 20 & 102,450 & 10,919 & 101,925 & 10,609 & 1,432 & 0,256 \\
\hline E-LS & 20 & 1,245 & 2,511 & 1,860 & 2,320 & 0,708 & $\mathbf{0 , 0 0 3 *}$ \\
\hline E-Li & 20 & $-0,475$ & 2,508 & $-0,855$ & 2,202 & 0,636 & 0,056 \\
\hline \hline
\end{tabular}

* significância estatística ao nível de 5\%

Após a análise dos resultados anteriores, observa-se que, no erro sistemático determinado por meio do teste $t$ dependente, dentre 26 variáveis, somente 3 apresentaram diferença estatisticamente significante, em um nível de significância de 5\%; representando $11,5 \%$ do total . É importante ressaltar que apesar da diferença significante, a média entre a primeira e a segunda medição das variáveis significantes não ultrapassou $1,5^{\circ}$ e/ou $1 \mathrm{~mm}$, o que tornaria realmente significante (tabela 2). 


\section{Dimorfismo dos Gêneros}

A tabela 3 demonstra a compatibilidade das idades inicial e final entre os gêneros feminino e masculino, assim como o tempo de tratamento com valores mínimos e máximos.

TABELA 3 - Média, desvio-padrão e grau de significância para idade inicial, idade final e tempo de tratamento em relação aos gêneros feminino e masculino (teste $t$ independente)

\begin{tabular}{|c|c|c|c|c|c|c|}
\hline \multirow[t]{2}{*}{$\begin{array}{c}\text { VARIÁVEIS } \\
\text { (ANO) }\end{array}$} & \multicolumn{2}{|c|}{$\begin{array}{c}\text { GÊNERO } \\
\text { FEMININO } \\
(N=15)\end{array}$} & \multicolumn{2}{|c|}{$\begin{array}{c}\text { GÊNERO } \\
\text { MASCULINO } \\
(N=15)\end{array}$} & \multirow[t]{2}{*}{$p$} & \multirow[t]{2}{*}{ Sig } \\
\hline & MÉDIA & $D P$ & MÉDIA & $D P$ & & \\
\hline IDADE INICIAL & 13,701 & 1,149 & 13,557 & 1,576 & 0,776 & n.s. \\
\hline IDADE FINAL & 14,280 & 1,234 & 14,073 & 1,612 & 0,696 & n.s. \\
\hline $\begin{array}{l}\text { TEMPO } \\
\text { TRATAMENTO }\end{array}$ & 0,579 & 0,225 & 0,516 & 0,353 & 0,567 & n.s. \\
\hline
\end{tabular}

* significância estatística ao nível de 5\%

Realizou-se o estudo do dimorfismo dos gêneros, aplicando-se o teste estatístico $t$ de Student, com o intuito de investigar se existem diferenças estatisticamente significantes entre os gêneros. Como demonstrado na tabela 4, observou-se que apenas a variável ANB apresentou significância estatística; sendo que a alteração média para o gênero feminino mostrou como resultado valor negativo. 
TABELA 4 - Resultado para o teste $t$ de Student em relação ao dimorfismo genérico

\begin{tabular}{|c|c|c|c|c|c|}
\hline \multirow[t]{2}{*}{ VARIÁVEIS } & \multicolumn{2}{|c|}{$\begin{array}{c}\text { GÊNERO FEMININO } \\
\qquad(N=15)\end{array}$} & \multicolumn{2}{|c|}{$\begin{array}{c}\text { GÊNERO MASCULINO } \\
\qquad(N=15)\end{array}$} & \multirow[t]{2}{*}{$p$} \\
\hline & MÉDIA & $D P$ & MÉDIA & $D P$ & \\
\hline
\end{tabular}

COMPONENTES DENTOALVEOLARES ANGULAR E LINEAR

\begin{tabular}{c|c|c|c|c|c}
\hline SN.7 & $-5,787$ & 4,966 & $-5,567$ & 6,437 & 0,917 \\
\hline SN.6 & $-7,413$ & 4,958 & $-9,753$ & 4,458 & 0,185 \\
\hline SN.5 & 11,080 & 5,528 & 9,273 & 4,863 & 0,350 \\
\hline SN.1 & 2,947 & 5,641 & 2,893 & 4,170 & 0,977 \\
\hline PTV-7 & $-1,380$ & 1,371 & $-1,360$ & 3,236 & 0,983 \\
\hline PTV-6 & $-1,487$ & 1,297 & $-1,680$ & 3,243 & 0,832 \\
\hline PTV-5 & 3,320 & 1,428 & 3,207 & 2,857 & 0,892 \\
\hline PTV-1 & 1,533 & 1,908 & 1,760 & 2,712 & 0,793 \\
\hline PP-7 & 0,187 & 1,903 & 0,180 & 1,927 & 0,992 \\
\hline PP-6 & $-0,280$ & 0,982 & $-0,047$ & 0,908 & 0,505 \\
\hline PP-5 & 1,553 & 1,084 & 1,813 & 1,125 & 0,524 \\
\hline PP-1 & 0,500 & 1,242 & 0,320 & 1,332 & 0,705 \\
\hline $\begin{array}{c}\text { TRESPASSE } \\
\text { HORIZONTAL }\end{array}$ & 0,767 & 1,959 & 1,240 & 1,107 & 0,422 \\
\hline $\begin{array}{c}\text { TRESPASSE } \\
\text { VERTICAL }\end{array}$ & $-0,693$ & 1,219 & $-0,767$ & 1,193 & 0,869 \\
\hline
\end{tabular}

COMPONENTES ESQUELÉTICOS ANGULARES E LINEARES

\begin{tabular}{c|c|c|c|c|c}
\hline SNA & 0,060 & 0,876 & 0,647 & 2,020 & 0,311 \\
\hline SNB & 0,193 & 1,254 & $-0,040$ & 1,515 & 0,649 \\
\hline ANB & $-0,127$ & 0,736 & 0,707 & 0,889 & $\mathbf{0 , 0 0 9 ^ { * }}$ \\
\hline PTV-A & 0,213 & 0,867 & 1,187 & 2,744 & 0,201 \\
\hline PTV-B & 0,633 & 1,739 & 0,280 & 4,455 & 0,777 \\
\hline
\end{tabular}

Continua... 
Continuação...

\begin{tabular}{|c|c|c|c|c|c|}
\hline \multirow[t]{2}{*}{ VARIÁVEIS } & \multicolumn{2}{|c|}{$\begin{array}{c}\text { GÊNERO FEMININO } \\
\qquad(N=15)\end{array}$} & \multicolumn{2}{|c|}{$\begin{array}{c}\text { GÊNERO MASCULINO } \\
\qquad(N=15)\end{array}$} & \multirow[t]{2}{*}{$p$} \\
\hline & MÉDIA & $D P$ & MÉDIA & $D P$ & \\
\hline
\end{tabular}

PADRÃO DE CRESCIMENTO

\begin{tabular}{c|c|c|c|c|c}
\hline FMA & 0,480 & 1,676 & 0,953 & 2,807 & 0,579 \\
\hline SN.GoGn & $-0,060$ & 1,957 & 1,140 & 3,077 & 0,213 \\
\hline NS.Gn & 1,613 & 1,205 & 2,500 & 2,395 & 0,211 \\
\hline AFAI & 1,567 & 0,993 & 2,673 & 2,104 & 0,076 \\
\hline
\end{tabular}

PERFIL TEGUMENTAR

\begin{tabular}{c|c|c|c|c|c}
\hline ANL & $-4,033$ & 10,727 & $-0,520$ & 8,861 & 0,336 \\
\hline E-LS & $-0,440$ & 0,863 & $-0,340$ & 1,328 & 0,809 \\
\hline E-Li & $-0,720$ & 0,878 & $-0,440$ & 1,262 & 0,486 \\
\hline \hline
\end{tabular}

* significância estatística ao nível de 5\%

Os valores iniciais e finais das variáveis analisadas com relação ao esqueleto cefálico, estruturas dentárias e tegumentares, decorrentes da distalização dos molares superiores por meio do aparelho Jones jig constam na tabela 5 .

TABELA 5 - Resultados do teste $t$ dependente para dados pareados

\begin{tabular}{c|c|c|c|c|c|c}
\hline \hline VARIÁVEIS & $N$ & MÉDIA & DP & MÉDIA & DP & $p$ \\
& & INICIAL & INICIAL & FINAL & FINAL & \\
\hline
\end{tabular}

COMPONENTES DENTOALVEOLARES ANGULAR E LINEAR

\begin{tabular}{c|l|c|c|c|c|c}
\hline SN.7 & 30 & 66,283 & 6,937 & 60,607 & 6,211 & $\mathbf{0 , 0 0 0 ^ { * }}$ \\
\hline SN.6 & 30 & 77,617 & 5,907 & 69,033 & 6,573 & $\mathbf{0 , 0 0 0 ^ { * }}$ \\
\hline SN.5 & 30 & 81,293 & 5,264 & 91,470 & 5,877 & $\mathbf{0 , 0 0 0 *}$ \\
\hline SN.1 & 30 & 107,893 & 6,019 & 110,120 & 6,705 & 0,051 \\
\hline PTV-7 & 30 & 12,767 & 2,937 & 11,397 & 3,112 & $\mathbf{0 , 0 0 5 *}$ \\
\hline PTV-6 & 30 & 22,067 & 3,441 & 20,483 & 3,471 & $\mathbf{0 , 0 0 \mathbf { 0 0 } ^ { * }}$ \\
\hline PTV-5 & 30 & 30,477 & 3,561 & 33,740 & 3,624 & $\mathbf{0 , 0 0 0 *}$ \\
\hline & & \multicolumn{3}{c}{ Continua... }
\end{tabular}


Continuação...

\begin{tabular}{l|c|c|c|c|c|c} 
VARIÁVEIS & $N$ & MÉDIA & DP & MÉDIA & DP & \\
INICIAL & INICIAL & FINAL & FINAL & $p$ \\
\hline
\end{tabular}

COMPONENTES DENTOALVEOLARES ANGULAR E LINEAR

\begin{tabular}{c|c|c|c|c|c|c}
\hline PTV-1 & 30 & 55,420 & 4,694 & 57,067 & 4,949 & $\mathbf{0 , 0 0 1}^{*}$ \\
\hline PP-7 & 30 & 12,187 & 3,822 & 12,370 & 3,314 & 0,598 \\
\hline PP-6 & 30 & 16,960 & 2,123 & 16,797 & 2,159 & 0,347 \\
\hline PP-5 & 30 & 18,890 & 2,246 & 20,573 & 2,183 & $\mathbf{0 , 0 0 0 *}$ \\
\hline PP-1 & 30 & 26,210 & 2,900 & 26,620 & 2,479 & 0,087 \\
\hline $\begin{array}{c}\text { TRESPASSE } \\
\text { HORIZONTAL }\end{array}$ & 30 & 4,897 & 1,660 & 5,900 & 2,337 & $\mathbf{0 , 0 0 2 ^ { * }}$ \\
\hline $\begin{array}{c}\text { TRESPASSE } \\
\text { VERTICAL }\end{array}$ & 30 & 4,130 & 1,375 & 3,400 & 1,766 & $\mathbf{0 , 0 0 2 *}$ \\
\hline
\end{tabular}

COMPONENTES ESQUELÉTICOS ANGULARES E LINEARES

\begin{tabular}{c|c|c|c|c|c|c}
\hline SNA & 30 & 83,103 & 4,366 & 83,457 & 3,914 & 0,224 \\
\hline SNB & 30 & 79,240 & 3,786 & 79,317 & 3,453 & 0,762 \\
\hline ANB & 30 & 3,867 & 2,149 & 4,157 & 2,336 & 0,091 \\
\hline PTV-A & 30 & 48,170 & 4,086 & 48,870 & 4,059 & 0,073 \\
\hline PTV-B & 30 & 46,893 & 4,978 & 47,350 & 5,553 & 0,458 \\
\hline
\end{tabular}

PADRÃO DE CRESCIMENTO

\begin{tabular}{c|l|l|l|l|l|l}
\hline FMA & 30 & 26,350 & 4,685 & 27,067 & 5,323 & 0,096 \\
\hline SN.GoGn & 30 & 32,037 & 4,556 & 32,577 & 4,647 & 0,266 \\
\hline NS.Gn & 30 & 58,020 & 5,008 & 60,077 & 4,647 & $\mathbf{0 , 0 0 0 *}$ \\
\hline AFAl & 30 & 60,877 & 5,234 & 62,997 & 5,295 & $\mathbf{0 , 0 0 0 *}$ \\
\hline
\end{tabular}

PERFIL TEGUMENTAR

\begin{tabular}{c|c|c|c|c|c|c}
\hline ANL & 30 & 106,980 & 15,363 & 104,730 & 9,011 & 0,250 \\
\hline E-LS & 30 & 1,690 & 2,309 & 1,300 & 2,326 & 0,062 \\
\hline E-Li & 30 & 0,197 & 2,261 & $-0,383$ & 1,950 & $\mathbf{0 , 0 0 6}^{*}$ \\
\hline \hline
\end{tabular}

* significância estatística ao nível de 5\% 
Na tabela 5, o teste $t$ dependente demonstrou que, das 26 variáveis analisadas, 12 apresentaram alterações estatisticamente significantes diante de um nível de significância de 5\%. Observa-se uma predominância quanto às alterações dentárias, visto que, do total, apenas 2 variáveis, a AFAI e NS.Gn, relacionam-se a modificações esqueléticas. Sendo assim, observaram-se basicamente alterações dentárias, que se seguem: SN.7, SN.6, SN.5, PTV-7, PTV-6, PTV-5, PTV-1, PP-5, E-Li e trespasse horizontal.

Alterações esqueléticas estatisticamente significantes não foram observadas. Com relação ao padrão de crescimento, o ângulo FMA apresentou um ligeiro aumento, no entanto, não foi significante estatisticamente. Porém,a altura facial ântero-inferior (AFAl) aumentou de $60,87 \mathrm{~mm}$ para $62,99 \mathrm{~mm}$, sendo que essa alteração foi estatisticamente significante. Já no perfil tegumentar comprovou-se uma alteração significante na variável E-Li; demonstrando uma protrusão do lábio inferior; porém, não ocorreu alteração estatisticamente significante com o ângulo nasolabial e com o posicionamento do lábio superior em relação ao plano estético.

As variáveis referentes ao componente dentoalveolar superior apresentaram, na maioria, alterações estatisticamente significantes, como SN.7, SN.6, SN.5, PTV-7, PTV-6, PTV-5, PTV-1, PP-5. As medidas referentes aos segundo e primeiro molares superiores e ao segundo pré-molar superior resultaram ao final da distalização em uma alteração na abertura angular, o que significa uma maior angulação distal e mesial desses dentes respectivamente. As variáveis PTV-7 e PTV-6, também demonstraram alterações estatisticamente significantes, ou seja, ocorreu uma redução linear quanto à distância entre o centro da coroa desses dentes à linha vertical pterigomaxilar, consequentemente, comprovou-se a distalização dos molares superiores. O mesmo ocorreu para PTV-5 e PTV-1, no entanto, o valor final aumentou em relação ao inicial, comprovando a mesialização dos dentes de ancoragem; isto é, a perda de ancoragem.

Quanto às medidas no sentido vertical, somente a variável PP-5 apresentou alteração estatisticamente significante. Observou-se que a distalização dos molares superiores resultou em um movimento de extrusão dos segundos pré-molares superiores, já que inicialmente o valor médio para PP-5 foi de 18,89; sendo o valor final de 20,57. 


\section{Severidade da Classe II}

A tabela 6 demonstra a distribuição da má oclusão de Classe II dente os 30 pacientes avaliados e tabela 7 apresenta os resultados para 0 teste $\mathrm{t}$ dependente de pacientes com até $1 / 2$ Classe II.

TABELA 6 - Distribuição quanto à severidade da má oclusão de Classe II

\begin{tabular}{l|c|c|c|c|c}
\hline \hline $\begin{array}{l}\text { RELAÇÃO } \\
\text { MOLAR }\end{array}$ & $\begin{array}{c}\text { 1/4 CLASSE } \\
\text { II }\end{array}$ & $\begin{array}{c}\text { 1/2 CLASSE } \\
\text { /I }\end{array}$ & $\begin{array}{c}\text { 3/4 CLASSE } \\
\text { /I }\end{array}$ & $\begin{array}{c}\text { CLASSE II } \\
\text { COMPLETA }\end{array}$ & TOTAL \\
\hline PACIENTES & $9(30 \%)$ & $12(40 \%)$ & $5(16,7 \%)$ & $4(13,3 \%)$ & 30 \\
\hline \hline
\end{tabular}

Partindo-se da afirmação de que os distalizadores intrabucais ${ }^{76,127,157}$ alcançam resultados mais satisfatórios diante de uma discrepância ânteroposterior menos severa; realizou-se um teste $t$ dependente a partir das alterações dos pacientes com até $1 / 2$ Classe $\mathrm{II}$, ou seja, 9 pacientes com má oclusão entre $3 / 4$ e Classe II completa foram excluídos "temporariamente". Os resultados encontram-se na tabela a seguir; sendo que apenas duas grandezas cefalométricas apresentaram resultados diferentes em relação à tabela 5 , ou seja, as variáveis PTV-7 e E-Li apresentavam anteriormente alterações estatisticamente significantes, sendo que, ao diminuir a severidade da Classe II, as alterações finais dessas variáveis não resultaram em significância.

TABELA 7 - Resultados do teste $t$ dependente para dados pareados em pacientes com no máximo $1 / 2$ Classe II

\begin{tabular}{c|c|c|c|c|c|c}
\hline \hline VARIÁVEIS & $N$ & MÉDIA & DP & MÉDIA & DP & $p$ \\
& & INICIAL & INICIAL & FINAL & FINAL & \\
\hline
\end{tabular}

COMPONENTE DENTOALVEOLAR ANGULAR E LINEAR

\begin{tabular}{c|c|c|c|c|c|c}
\hline SN.7 & 21 & 66,329 & 7,614 & 60,929 & 6,875 & $\mathbf{0 , 0 0 \mathbf { 0 1 } ^ { * }}$ \\
\hline SN.6 & 21 & 78,019 & 5,760 & 69,790 & 6,761 & $\mathbf{0 , 0 0 0 ^ { * }}$ \\
\hline SN.5 & 21 & 81,733 & 5,084 & 90,476 & 4,582 & $\mathbf{0 , 0 0 0 ^ { * }}$ \\
\hline SN.1 & 21 & 109,171 & 5,733 & 110,067 & 5,534 & 0,340 \\
\hline
\end{tabular}

Continua... 
Continuação...

VARIÁVEIS

\begin{tabular}{|c|c|c|c|c|c}
$N$ & MÉDIA & DP & MÉDIA & DP & $p$ \\
INICIAL & INICIAL & FINAL & FINAL & $p$ \\
\hline
\end{tabular}

COMPONENTE DENTOALVEOLAR ANGULAR E LINEAR

\begin{tabular}{c|l|c|c|c|c|c}
\hline PTV-7 & 21 & 12,428 & 3,137 & 11,295 & 3,447 & 0,076 \\
\hline PTV-6 & 21 & 21,638 & 3,742 & 20,271 & 3,831 & $\mathbf{0 , 0 3 4}^{*}$ \\
\hline PTV-5 & 21 & 29,971 & 3,817 & 33,114 & 3,653 & $\mathbf{0 , 0 0 0}^{*}$ \\
\hline PTV-1 & 21 & 55,143 & 4,664 & 56,638 & 4,996 & $\mathbf{0 , 0 1 3 ^ { * }}$ \\
\hline PP-7 & 21 & 11,771 & 4,180 & 12,252 & 3,609 & 0,297 \\
\hline PP-6 & 21 & 17,181 & 2,043 & 16,905 & 2,137 & 0,196 \\
\hline PP-5 & 21 & 19,148 & 2,193 & 20,800 & 2,084 & $\mathbf{0 , 0 0 0 ^ { * }}$ \\
\hline PP-1 & 21 & 26,395 & 3,028 & 26,862 & 2,473 & 0,117 \\
\hline $\begin{array}{c}\text { TRESPASSE } \\
\text { HORIZONTAL }\end{array}$ & 21 & 4,638 & 1,382 & 5,195 & 1,734 & $\mathbf{0 , 0 1 8 ^ { * }}$ \\
\hline $\begin{array}{c}\text { TRESPASSE } \\
\text { VERTICAL }\end{array}$ & 21 & 3,686 & 1,243 & 3,200 & 1,669 & $\mathbf{0 , 0 4 7 *}$ \\
\hline
\end{tabular}

COMPONENTES ESQUELÉTICOS ANGULARES E LINEARES

\begin{tabular}{c|c|c|c|c|c|c}
\hline SNA & 21 & 83,062 & 3,870 & 83,481 & 3,376 & 0,276 \\
\hline SNB & 21 & 79,524 & 3,642 & 79,671 & 3,202 & 0,658 \\
\hline ANB & 21 & 3,543 & 2,057 & 3,824 & 2,233 & 0,200 \\
\hline PTV-A & 21 & 47,538 & 3,883 & 48,362 & 3,973 & 0,137 \\
\hline PTV-B & 21 & 46,543 & 5,151 & 47,114 & 6,026 & 0,513 \\
\hline
\end{tabular}

\section{PADRÃO DE CRESCIMENTO}

\begin{tabular}{c|l|l|l|l|l|l}
\hline FMA & 21 & 26,338 & 4,788 & 27,295 & 5,489 & 0,052 \\
\hline SN.GoGn & 21 & 31,886 & 4,962 & 32,495 & 4,821 & 0,359 \\
\hline NS.Gn & 21 & 58,052 & 5,204 & 59,976 & 4,777 & $\mathbf{0 , 0 0 0}^{*}$ \\
\hline AFAl & 21 & 60,819 & 5,285 & 62,767 & 5,450 & $\mathbf{0 , 0 0 0 *}$ \\
\hline
\end{tabular}

\section{PERFIL TEGUMENTAR}

\begin{tabular}{l|l|c|c|c|c|c} 
ANL & 21 & 107,367 & 16,035 & 104,548 & 9,425 & 0,241 \\
\hline E-LS & 21 & 1,586 & 2,505 & 1,305 & 2,563 & 0,268 \\
\hline E-Li & 21 & $-0,319$ & 2,432 & $-0,748$ & 2,175 & 0,102 \\
\hline
\end{tabular}

* significância estatística ao nível de 5\% 


\section{Presença dos Segundos Molares Superiores}

A partir dos pacientes pertencentes à amostra estudada, avaliou-se a influência dos segundos molares quanto à quantidade de distalização dos primeiros molares e a mesialização dos segundos pré-molares, isto é, a ocorrência da perda de ancoragem. De acordo com os resultados obtidos, pode-se afirmar que os segundos molares superiores não influenciam significantemente na efetividade da correção molar de Classe II e não intensificam a perda de ancoragem, apenas interferem na angulação dos molares distalizados conforme demonstra os resultados da tabela 8.

TABELA 8 - Avaliação das alterações dentárias lineares e angulares diante da presença dos segundos molares superiores (teste $t$ independente)

\begin{tabular}{|c|c|c|c|c|c|}
\hline \multirow[t]{2}{*}{ VARIÁVEIS } & \multicolumn{2}{|c|}{$\begin{array}{c}\text { NÃO IRROMPIDOS } \\
(\mathbf{N}=7)\end{array}$} & \multicolumn{2}{|c|}{$\begin{array}{l}\text { IRROMPIDOS } \\
\qquad(N=23)\end{array}$} & \multirow[t]{2}{*}{$p$} \\
\hline & MÉDIA & DP & MÉDIA & DP & \\
\hline PTV-6 (FINAL- INICIAL) & $-2,986$ & 2,301 & $-2,096$ & 1,583 & 0,252 \\
\hline PTV-5 (FINAL- INICIAL) & 1,943 & 2,464 & 3,665 & 2,029 & 0,071 \\
\hline SN.6 (FINAL- INICIAL) & $-11,671$ & 3,084 & $-7,643$ & 4,858 & $0,049 *$ \\
\hline SN.5 (FINAL- INICIAL) & 10,543 & 4,195 & 10,065 & 5,546 & 0,836 \\
\hline
\end{tabular}

\section{Alterações Mensais}

TABELA 9 - Resultado da distalização mensal dos primeiros molares e mesialização mensal dos segundos pré-molares superiores, média, desviopadrão, valores mínimos e máximos

\begin{tabular}{c|c|c|c|c}
\hline \hline VARIÁVEIS (mm) & MÉDIA & DP & MÍNIMA & MÁXIMA \\
\hline DISTALIZAÇÃO MENSAL (PTV-6) & 0,434 & 0,447 & 0,014 & 1,987 \\
\hline MESIALIZAÇÃO MENSAL (PTV-5) & $-0,545$ & $-0,505$ & $-2,352$ & $-0,830$ \\
\hline \hline
\end{tabular}


Observa-se que a distalização mensal está representada por valores positivos e a mesialização dos pré-molares é demonstrada em valores negativos, portanto, a partir dos resultados nota-se que a quantidade de perda de ancoragem foi superior à quantidade de distalização dos molares distalizados.

\section{Correlação das Variáveis Dentárias e Esqueléticas}

A fim de avaliar o grau de correlação entre duas variáveis quantitativas, realizou-se a Correlação de Pearson, verificando o grau de linearidade dos pontos.

TABELA 10 - Teste de correlação entre as alterações das medidas dentárias PTV-5, PTV-6 e PTV-7 e as alterações das variáveis PTV-1, PTV-7, PTV-5 e PP-6

\begin{tabular}{l|c|c}
\hline \hline \multicolumn{1}{c|}{ VARIÁVEIS } & $\boldsymbol{r}$ & $\boldsymbol{p}$ \\
\hline PTV-5 x PTV-1 & 0,8112 & $\mathbf{0 , 0 0 0 ^ { * }}$ \\
\hline PTV-5 x PTV-7 & 0,7991 & $\mathbf{0 , 0 0 0 ^ { * }}$ \\
\hline PTV-6 x PTV-1 & 0,7194 & $\mathbf{0 , 0 0 0 ^ { * }}$ \\
\hline PTV-6 x PTV-7 & 0,9483 & $\mathbf{0 , 0 0 0 ^ { * }}$ \\
\hline PTV-6 x PTV-5 & 0,8022 & $\mathbf{0 , 0 0 0 ^ { * }}$ \\
\hline PTV-6 x PP-6 & 0,4974 & $\mathbf{0 , 0 0 5 ^ { * }}$ \\
\hline PTV-1 x PTV-7 & 0,7678 & $\mathbf{0 , 0 0 0 *}$ \\
\hline PTV-5 x PTV-7 & 0,7991 & $\mathbf{0 , 0 0 0 *}$ \\
\hline \hline
\end{tabular}

A tabela 10 correlaciona as variáveis dentárias que determinam a distalização e demonstrou correlações estatisticamente significantes de PTV-1 em relação às variáveis PTV-5, PTV-6, PTV-7, isto é, confirmando que a inclinação vestibular dos incisivos superiores é maior conforme a distalização dos primeiros e segundos molares e a mesialização dos segundos pré-molares superiores aumentam. Também foi observada correlação significante de PTV-7 com PTV-5 e PTV-6, ou seja, a distalização dos segundos molares superiores 
apresentou correlação com a distalização dos primeiros molares superiores e com a mesialização dos segundos pré-molares superiores.

Observou-se uma correlação entre a mesialização dos segundos présuperiores; isto é, PTV-5 em relação à PTV-6 e PTV-7; assim como PTV-6 com PP-6, ou seja, a distalização dos primeiros molares superiores se correlaciona com sua alteração vertical, que neste estudo, foi demonstrada pela intrusão dos primeiros molares superiores.

$\mathrm{Na}$ tabela 11 foi possível observar uma correlação entre a extrusão dos pré-molares em relação às variáveis do padrão cefálico SN.GoGn, NS.Gn e AFAl; da mesma forma observou-se uma correlação significante entre as variáveis PP-6 e PP-7 e as medidas esqueléticas NS.Gn e AFAI. Também foi observada correlação estatisticamente significante entre as medidas SN.5 e SN.1; SN.6 e trespasse vertical.

TABELA 11 - Teste de correlação entre as alterações das medidas dentárias PP-5, PP-6, PP-7, SN.5 e SN.6 e as alterações das variáveis SN.GoGn, NS.Gn, trespasse vertical e SN.1

\begin{tabular}{l|c|c}
\hline \multicolumn{1}{c|}{ VARIÁVEIS } & $\boldsymbol{r}$ & $\boldsymbol{p}$ \\
\hline PP-5 $\times$ SN.GoGn & 0,4303 & $\mathbf{0 , 0 1 8}^{*}$ \\
\hline PP-5 x NS.Gn & 0,6060 & $\mathbf{0 , 0 0 0 ^ { * }}$ \\
\hline PP-5 x AFAI & 0,6125 & $\mathbf{0 , 0 0 0 ^ { * }}$ \\
\hline PP-5 x TRESPASSE VERTICAL & 0,0225 & 0,906 \\
\hline PP-6 x SN.GoGn & 0,2295 & 0,222 \\
\hline PP-6 x NS.Gn & 0,7199 & $\mathbf{0 , 0 0 0 *}$ \\
\hline PP-6 x AFAI & 0,6804 & $\mathbf{0 , 0 0 0 *}$ \\
\hline PP-6 x TRESPASSE VERTICAL & 0,2516 & 0,180 \\
\hline PP-7 x SN.GoGn & 0,3837 & 0,036 \\
\hline PP-7 x NS.Gn & 0,6316 & $\mathbf{0 , 0 0 0 *}$ \\
\hline PP-7 x AFAI & 0,5297 & $\mathbf{0 , 0 0 3 *}$ \\
\hline PP-7 x TRESPASSE VERTICAL & 0,3488 & 0,059 \\
\hline
\end{tabular}

Continua... 
Continuação...

\begin{tabular}{l|c|c}
\multicolumn{1}{c|}{ VARIÁVEIS } & $\boldsymbol{r}$ & $\boldsymbol{p}$ \\
\hline SN.5 $\times$ SN.GoGn & $-0,2950$ & 0,114 \\
\hline SN.5 x NS.Gn & $-0,0853$ & 0,654 \\
\hline SN.5 x AFAI & $-0,1698$ & 0,370 \\
\hline SN.5 x TRESPASSE VERTICAL & $-0,2790$ & 0,135 \\
\hline SN.5 x SN.1 & 0,6170 & $\mathbf{0 , 0 0 0 *}$ \\
\hline SN.6 x SN.GoGn & $-0,2868$ & 0,124 \\
\hline SN.6 x NS.Gn & $-0,0084$ & 0,965 \\
\hline SN.6 x AFAI & $-0,0714$ & 0,708 \\
\hline SN.6 x TRESPASSE VERTICAL & 0,4134 & $\mathbf{0 , 0 2 3}$ \\
\hline SN.6 x SN.1 & $-0,2870$ & 0,124 \\
\hline \hline
\end{tabular}



DiscLESẼTO 



\section{6 - DISCUSSÃO}

A discussão nada mais é do que a oportunidade de esclarecer os componentes envolvidos neste estudo de forma a discernir as variáveis aqui apresentadas, sendo assim, torna-se lícito explanar a respeito da amostra e da metodologia utilizadas e dos resultados obtidos ao final deste experimento clínico.

Visando avaliar especificamente os efeitos decorrentes do distalizador Jones jig, o momento de remoção desse aparelho foi considerado como a etapa final de avaliação desta pesquisa, uma vez que, outras variáveis (colocação da ancoragem extrabucal e a cooperação do paciente) seriam incorporadas aos resultados alcançados, podendo dessa forma, mascarar os efeitos específicos do distalizador Jones jig.

\subsection{Precisão da Metodologia}

Os pacientes foram radiografados em dois tempos: ao início do tratamento e ao término da fase experimental, para obtenção das telerradiografias em norma lateral a fim de se avaliarem as alterações correspondentes à distalização.

A radiografia cefalométrica nada mais é do que um recurso ímpar para o diagnóstico, planejamento e acompanhamento ortodôntico. Contudo, para confiabilidade dos resultados, torna-se necessário determinar 0 erro proveniente do traçado cefalométrico, da marcação e da digitalização dos pontos.

Seqüencialmente, foram obtidos os cefalogramas das fases inicial e pósdistalização. Todos os cefalogramas foram realizados por um único profissional, com o mesmo negatoscópio, em sala obscurecida em um período de no máximo uma semana ${ }^{67}$. Os pontos cefalométricos foram demarcados e as medições realizadas pelo programa Dentofacial Planner $7.02^{\mathrm{a}}$; obedecendo a correção do fator de magnificação em 6\% e 9,8\% como será detalhadamente explicado no decorrer desta discussão.

\footnotetext{
a Dentofacial Planner Software Inc., Toronto, Ontário, Canadá.
} 
A partir da digitalização e obtenção dos resultados, após um intervalo de 30 dias, selecionou-se aleatoriamente 20 pacientes, valor esse superior aos estudos de Brickman, Sinha, Nanda ${ }^{23}$ e Gulati; Kharbanda; Parkash ${ }^{70}$, e que correspondeu a 66,7\% (40 telerradiografias) do total das radiografias traçadas neste estudo ${ }^{12}$. Para os pacientes selecionados, foram traçados novos cefalogramas das fases inicial e final. Desta forma, possibilitou-se comparar as primeiras e as segundas medições, o que resultou no erro intra-examinador ${ }^{85}$.

O erro metodológico refere-se a dois tipos distintos: erro sistemático e casual. O erro sistemático ocorre quando uma determinada medida é sub ou superestimada. A partir do momento que este erro aconteça diante de um único examinador, sugere-se a ocorrência de mudanças na técnica de mensuração ou até mesmo uma tendenciosidade subconsciente do examinador em direcionar os resultados de acordo com suas próprias expectativas ${ }^{85}$. Por outro lado, o erro casual corresponde à dificuldade em definir ou identificar certos pontos, geralmente em conseqüência da imprecisão de certas estruturas ${ }^{85}$.

Para a verificação da significância estatística do erro sistemático utilizouse o teste $t$ de Student, ao nível de $5 \%$, e para o erro casual a fórmula de Dahlberg $^{43}$. Para a interpretação do erro casual, baseando-se nas pesquisas de Sandler ${ }^{144}$ e de Liu; Gravelly ${ }^{112}$ considerou-se os valores do índice de Dahlberg $^{43}$ acima de $1,5^{\circ}$ e de $1 \mathrm{~mm}$ como erros significantes. Portanto os resultados encontrados neste estudo estão de acordo com a literatura, visto que apenas $11,5 \%$ das variáveis apresentaram erro sistemático e com relação ao erro casual, nenhuma grandeza cefalométrica apresentou alteração significante ${ }^{112,144}$ (Tabela 2, p. 105).

Outra questão a ser discutida refere-se ao fator de magnificação, que corresponde à porcentagem de ampliação da imagem radiográfica em relação ao tamanho real das estruturas do complexo craniofacial. Neste estudo corrigiu-se esse fator a partir dos valores de $6 \%$ e 9,8\%. Raros são os estudos que referenciam ou especificam a correção do fator de magnificação ${ }^{23-26,60,76}$. Entretanto, estudos recentes têm se conscientizado da importância em especificar a magnificação, principalmente, visando a possibilidade de realizar estudos comparativos de maior coerência; já que a diferença é significativa entre os valores que não forem devidamente corrigidos ${ }^{104,106,143}$. 


\subsection{Características da Amostra}

Inicialmente, para a obtenção da amostra, foram realizadas avaliações clínicas com o intuito de selecionar jovens com má oclusão de Classe II, $1^{\mathrm{a}}$ ou $2^{\mathrm{a}}$ divisão de Angle (Figura 4.1 a 4.4), apresentando no máximo um moderado apinhamento ântero-superior e inferior; idade inicial na faixa etária de 10 a 16 anos de idade e harmonia facial, isto é, clinicamente sem comprometimento esquelético. Procurou-se compatibilizar as idades iniciais; de forma a evitar que surgissem dúvidas quanto a diferenças no crescimento e desenvolvimento craniofacial (Tabela 1, p. 74).

Visando um estudo cientificamente satisfatório, o ideal seria comparar o grupo experimental a um grupo controle com características de má oclusão de Classe II não tratada; a fim de avaliar possíveis alterações dentoesqueléticas; contudo, os pacientes que fazem parte dessa amostra controle pertencente ao Centro de Crescimento da Disciplina de Ortodontia da Faculdade de Odontologia de Bauru, não apresentavam a média das idades finais compatíveis ao grupo tratado com o distalizador Jones jig. Justifica-se a não compatibilidade das idades finais em decorrência do longo intervalo entre os períodos de observação dos pacientes não tratados, impossibilitando a comparação com o grupo experimental, visto que, a distalização ocorreu em um curto espaço de tempo.

Portanto, essa comparação torna-se pouco relevante, visto que o tempo de tratamento com os distalizadores intrabucais não é prolongado ${ }^{75}$; sendo assim, de acordo com a grande maioria dos estudos científicos, não ocorrem alterações esqueléticas e dentoalveolares significantes decorrentes do crescimento e desenvolvimento craniofacial durante o período de tratamento $^{58,70,76,96,106,127}$ ou mesmo decorrente da utilização de distalizadores intrabucais ${ }^{25,26}$. No entanto, para outros autores, as alterações esqueléticas são decorrentes de movimentações dentárias, como o aumento da AFAl que se reflete na rotação póstero-inferior da mandíbula, possivelmente em conseqüência da extrusão dos molares e/ou pré-molares superiores ${ }^{23,32,60}$. Esses dados também puderam ser observados neste estudo, visto que as grandezas cefalométricas AFAl e NS.Gn aumentaram significantemente ao 
final da distalização; sendo em média uma diferença de 2,12mm e 1,98 respectivamente.

A alta prevalência da Classe II assim como a intensa procura por tratamento ortodôntico diante dessa alteração, certamente foram os desencadeadores para o aprofundamento científico a respeito dessa má oclusão. Diversos autores se propuseram a avaliar o comportamento oclusal da Classe II, assim como as diversas alternativas de tratamento ${ }^{4,75,77,78,80,91}$.

Com o advento das análises cefalométricas assim como a partir de estudos minuciosos, comprovou-se que a má oclusão de Classe II, além do comprometimento dentoalveolar, também se caracteriza por alterações esqueléticas; comprometendo maxila, mandíbula ou ambas, em diversas severidades.

Sendo assim, a maioria dos autores confirma a alta ocorrência da protrusão maxilar ${ }^{47,163}$, outros observam o posicionamento normal da maxila $^{84,86}$ ou ainda a sua retrusão ${ }^{74,135,152}$. Para esse estudo, o valor médio inicial de SNA corresponde a $83,10^{\circ}$, o que demonstra normalidade do posicionamento maxilar em relação à base do crânio, quando comparado aos valores pertencentes ao Atlas de Crescimento Craniofacial ${ }^{116}$, cujo valor de SNA, na idade de 13 anos, para o gênero masculino é de $82,0^{\circ}$, desvio padrão de $2,9^{\circ}$ e para o gênero feminino, $80,6^{\circ}$ com desvio padrão de $3,7^{\circ}$.

Ao avaliar os pacientes individualmente, observou-se que, em 53,3\%, a maxila encontrou-se bem posicionada em relação à base do crânio; em outros $40 \%$, ocorreu suave protrusão maxilar; e nos demais, 6,7\%, apresentaram uma leve retrusão da maxila.

Considerando a posição mandibular, a maioria dos autores confirma a retrusão da mandíbula como característica marcante na má oclusão de Classe II $^{47,66,84,86,119,128,135,152}$ e alguns relatam o posicionamento normal ${ }^{47,119,152}$. Neste estudo notou-se um comportamento de normalidade quanto ao posicionamento mandibular em relação à base craniana (SNB inicial médio de $79,24^{\circ}$ ) e ao comparar com os valores normais ${ }^{116}$, pacientes na idade de 13 anos apresentaram o ângulo SNB em $78,5^{\circ}$, desvio padrão de 2,9 $9^{\circ}$ para o gênero masculino e $77,9^{\circ}$, desvio padrão $3,4^{\circ}$, para 0 feminino. Diante da individualização da amostra, encontra-se a maioria, 66,7\%, com posicionamento mandibular normal em relação à base do crânio; outros 20\% 
dos pacientes com protrusão mandibular; e por fim 13,3\% sendo pacientes com retrusão mandibular.

A relação maxilomandibular, representada pela variável ANB, neste estudo, resultou em um valor médio inicial de $3,86^{\circ}$, demonstrando normalidade entre as bases apicais, visto que o valor médio normal para a idade de 13 anos no gênero masculino corresponde a $3,4^{\circ}\left( \pm 2,1^{\circ}\right)$ e no gênero feminino, $2,6^{\circ}$ $( \pm 1,6)^{116}$. Individualmente, o ANB mostrou-se dentro da normalidade para $63,3 \%$ dos pacientes, aumentado em 30\% e diminuído em 6,7\%.

O padrão do esqueleto cefálico para este estudo foi determinado a partir das grandezas cefalométricas: FMA, SN.GoGn; NS.Gn e AFAI. Diante de uma análise comparativa, observou-se uma tendência de padrão de crescimento equilibrado, sendo o valor médio de FMA para os pacientes tratados $26,35^{\circ}$; o que demonstra normalidade na faixa etária de 13 anos, já que para o gênero masculino esse ângulo corresponde a $30,6^{\circ}$, desvio padrão $3,7^{\circ}$ e para 0 feminino, $27,9^{\circ}$ com desvio padrão de $4,0^{\circ 116}$. O comportamento de equilíbrio do padrão cefálico também fora observado para a grandeza angular SN.GoGn, o valor médio inicial foi de $32,03^{\circ}$ (dados normais de $34,7^{\circ} \pm 3,3^{\circ}$ para o gênero masculino e $34,9^{\circ} \pm 4,6^{\circ}$ para o feminino ${ }^{116}$. Para a altura facial ântero-inferior (AFAl), o valor médio inicial foi de $60,87 \mathrm{~mm}$, sendo considerado abaixo da normalidade, ou seja, $68 \mathrm{~mm}( \pm 5,1)$ para o gênero masculino e $66,4 \mathrm{~mm}( \pm 4,3)$ para o feminino ${ }^{116}$. Individualmente, somente $3,3 \%$ da amostra apresentavam tendência de crescimento vertical (dolicocefálico); 36,7\% caracterizavam crescimento horizontal (braquicefálico) e a grande maioria dos pacientes, isto é; $60 \%$ dos jovens tratados apresentavam padrão de crescimento equilibrado (mesocefálico); sendo assim, comprova-se que para esses pacientes o tratamento com distalizadores intrabucais demonstrará certamente resultados satisfatórios $^{83,114,140}$.

Quanto ao posicionamento dos dentes em relação ao osso basal, cabe ressaltar o posicionamento ântero-posterior do primeiro molar superior em relação à linha PTV, seguindo os resultados do Atlas de Crescimento Craniofacial $^{116}$ (valores normais para a idade de 13 anos, gênero masculino 15,1 $\pm 3,4 \mathrm{~mm}$; feminino $15,1 \pm 2,5 \mathrm{~mm}$ ); portanto para este estudo a distância média do centro do primeiro molar superior à linha PTV inferior corresponde a $22,07 \mathrm{~mm}$. O aumento desta medida quando comparado ao valor padrão 
ocorre, certamente, em decorrência da principal característica da má oclusão de Classe II, em que os molares superiores localizam-se à frente dos molares inferiores. Neste estudo, a discrepância ântero-posterior variou para cada paciente, ou seja, a relação molar foi de $1 / 4,1 / 2,3 / 4$ e Classe II completa (Figura 6.7).

A partir de uma análise geral das características cefalométricas dos pacientes selecionados, destaca-se o posicionamento normal da maxila e da mandíbula, o que resulta obviamente em uma relação maxilomandibular satisfatória, com características de um padrão de crescimento equilibrado e posicionamento dentário característico de uma má oclusão de Classe II dentária; desta forma, conclui-se que os jovens pertencentes a essa amostra apresentavam componentes dentários e esqueléticos favoráveis a serem submetidos ao tratamento conservador por meio do distalizador Jones jig.

Torna-se lícito destacar como critério metodológico o tamanho da amostra avaliada. Uma quantidade significante de estudos direcionados à avaliação dos distalizadores intrabucais apresenta amostras clínicas com número reduzido de pacientes ${ }^{3,25,26,29,30,50,54,70,96,101,113-115,118,127,143,149}$ e abaixo da quantidade avaliada nesta pesquisa. Certamente, esse é um fator determinante e influente nos resultados obtidos. Conclusões baseadas em trabalhos com amostras de número limitado não são inteiramente confiáveis cientificamente, principalmente em decorrência da variabilidade individual, 0 que pode comprometer resultados finais. O presente estudo demonstra confiabilidade dos resultados, pois se caracteriza por uma pesquisa científica que obedece a normas de padronização; a amostra foi composta de 30 jovens brasileiros, 15 do gênero masculino e outros 15 do feminino, com idade compatível, sendo a média inicial de 13,31 anos (mínima de 10,83; máxima de $16,24)$.

\subsection{Considerações da Metodologia}

As grandezas cefalométricas foram criteriosamente selecionadas a fim de se evitar que alterações em estruturas à distância comprometessem a confiabilidade dos resultados. A metodologia foi baseada em estudos prévios 
referentes aos distalizadores intrabucais ${ }^{23,25,26,32,76,103-106,118,126,127,143}$, com 0 intuito de posteriormente realizar discussões confiáveis metodologicamente.

As alterações maxilomandibulares ântero-posteriores foram determinadas por meio das variáveis SNA, SNB e ANB. Tem-se conhecimento de que a base craniana pode apresentar diferentes angulações, no entanto essa variação não comprometeria significantemente os resultados deste estudo, visto que as medições ocorrem em um curto período de tempo ${ }^{143}$. As demais grandezas cefalométricas, FMA, SN.GoGn, NS.Gn e AFAI, referiram-se à avaliação do padrão cefálico e foram assim selecionadas por serem amplamente utilizadas e consagradas na literatura como as variáveis que melhor definem as características dos pacientes com relação ao padrão de crescimento craniofacial ${ }^{138,159}$

A avaliação do perfil mole foi realizada a partir de medidas lineares abrangendo o lábio superior (Ls), o lábio inferior (Li) e o plano estético (E), referenciado por Ricketts ${ }^{136}$. Outra alternativa para avaliar o perfil mole seria a utilização da linha $S$ de Steiner ${ }^{155}$, no entanto, optou-se pelo plano estético em decorrência da maior precisão na demarcação dos pontos cefalométricos ${ }^{14,136}$

A análise dentária referiu-se basicamente à demarcação de pontos nos primeiros e segundos molares superiores, segundos pré-molares superiores e incisivos centrais superiores. Diante da opção em se marcar os pontos na face mesial, distal ou centro da coroa clínica, preferiu-se a terceira referência, visto que diversos autores afirmam que o ponto ao centro da coroa clínica, localizado exatamente no ponto médio da maior convexidade das faces mesial e distal, representa fielmente as alterações dentárias ${ }^{23,25,26,60,126,143}$. As demarcações mesial e distal movimentam-se demasiadamente diante de uma angulação dentária para a distal, não refletindo claramente o movimento real do molar superior, evidenciando exageradamente um resultado de extrusão ou intrusão dos dentes avaliados.

O referencial para avaliar as alterações dentárias lineares correspondeu à linha vertical pterigomaxilar (que une a intersecção do plano esfenoidal com as asas maiores do esfenóide ao ponto mais inferior da fissura pterigomaxilar) considerada metodologicamente confiável, já que não se altera significantemente no sentido ântero-posterior em decorrência do crescimento 
craniofacial, sendo por isto amplamente utilizada na literatura como plano de referência sagital ${ }^{23,25,26,49,60,114,127}$.

As alterações dentárias relacionadas à angulação mesiodistal e ao sentido vertical tiveram como referência o plano palatino, seguindo vários estudos na literatura ${ }^{19,20,25,26,29,49,60}$. O plano de Frankfort ${ }^{45,57,137}$ assim como a base do crânio ${ }^{76,138,143,155}$ também são referenciais utilizados para avaliar movimentações dentárias, no entanto, esses planos de referência podem apresentar variações que levariam a interpretações errôneas quanto às alterações dentárias $^{16,89,93,95,137}$. O plano de Francfort tem como desvantagem as estruturas que o originam, isto é, é um plano construído a partir de uma média entre estruturas sobrepostas, sendo assim, torna-se subjetiva a obtenção dos pontos formadores do plano de Francfort. Ressalta-se também a localização do pano palatino, ou seja, sua maior proximidade com as estruturas dentárias a serem avaliadas, sugerindo-se maior confiabilidade das medições. Portanto, torna-se conveniente tomá-lo como referência a fim de representar criteriosamente as movimentações dentárias.

Com o intuito de obedecer a um controle metodológico, inicialmente, para obtenção da amostra seguiu-se um critério rigoroso de seleção que já fora discutido anteriormente. Também se padronizou a confecção e instalação dos dispositivos intrabucais.

O botão de Nance modificado utilizado como reforço de ancoragem neste estudo, pode ser inserido nos primeiros e segundos pré-molares ou ainda segundos molares decíduos, portanto, difere do convencional, que é cimentado nos primeiros molares superiores ${ }^{96}$. O aparelho utilizado como reforço de ancoragem foi confeccionado por um único técnico assegurando a padronização quanto ao tamanho e extensão do acrílico e sua confecção obedecera às especificações de Runge; Martin; Bukai ${ }^{143}$ em que o diâmetro deveria ser de pelo menos $15 \mathrm{~mm}$; sendo assim, a extensão do botão de Nance modificado não ultrapassou $20 \mathrm{~mm}$ de diâmetro, evitando injúrias ao tecido mole do palato; da mesma forma, a instalação e ativação do distalizador foram realizadas pelo mesmo profissional; assegurando a quantidade de força despendida pela mola de NiTi.

O distalizador Jones jig utiizado neste estudo, inicialmente, recebeu modificações quanto ao tipo de mola para a distalização dos molares 
superiores, ou seja, substitui-se a mola de aço inox pela mola de níquel-titânio, já que a liga de NiTi dissipa uma força leve e contínua, promovendo um movimento dentário satisfatório ${ }^{123}$.

Após corrigir a relação molar, torna-se imprescindível realizar a sobrecorreção a fim de se compensar a recidiva da má oclusão de Classe $\|^{32,126,157}$. Para este estudo, a sobrecorreção foi de $2 \mathrm{~mm}$ em média, considerando que $1 \mathrm{~mm}$ não seria suficiente para evitar uma possível mesialização do molar distalizado ${ }^{32,127}$.

Em um estudo realizado por Toroglu et al. ${ }^{158}$ (2001) avaliou-se por um período de 3 meses o comportamento dentário ao final da distalização, o que comprova as considerações realizadas anteriormente. Observaram que os molares, pré-molares e incisivos superiores tendem a retornar à posição inicial; portanto os molares distalizados tendem a mesializar e os pré-molares e incisivos a distalizar, desta forma, justifica-se a sobrecorreção da relação molar.

Alcançada a sobrecorreção, faz-se necessário o uso de uma ancoragem nos molares distalizados, para isso indica-se a utilização de uma barra transpalatina, um arco de estabilização, botão de Nance ou ainda ancoragem extrabucal $^{157}$. Neste estudo, optou-se pelo botão de Nance cimentado nos primeiros molares superiores associado ao extrabucal de tração média-alta a fim de verticalizar a raiz dos molares distalizados, corrigindo a angulação exacerbada desses elementos dentários ${ }^{62}$. Diante dos efeitos indesejáveis, como alterações angulares e verticais dos molares superiores, recomenda-se a utilização de uma ancoragem extrabucal de tração média-alta, pois a ação é quase que praticamente radicular, sem interferir no posicionamento vertical desses dentes ${ }^{23}$. No entanto, o tratamento que tem por vantagem não depender exclusivamente do paciente, nessa fase exige total cooperação, visto que a não utilização desses dispositivos compromete o sucesso do tratamento, já que é necessária a correção radicular e finalização com a retração do segmento anterior. 


\subsection{Resultados}

\subsubsection{Compatibilidade da Amostra}

Embora a literatura relate o curto tempo de tratamento com os distalizadores intrabucais, o que conseqüentemente reflete em alterações esqueléticas não significantes ${ }^{70,76,96,127}$; a compatibilidade das idades inicial e final foi avaliada e, conseqüentemente, do tempo de tratamento, a fim de descartar possíveis dúvidas quanto aos resultados obtidos.

Entretanto, a literatura comprova que o crescimento e o desenvolvimento craniofacial diferem entre os gêneros, pois a maturação é adiantada e as características dentárias e esqueléticas são desenvolvidas mais precocemente no gênero feminino ${ }^{15,52,71}$. Jovens de diferentes gêneros, mesmo em idades cronológicas semelhantes, apresentam idades biológicas distintas e níveis de comportamento divergentes ${ }^{34}$. Portanto, verificou-se a compatibilidade das idades iniciais, já que esse é um importante dado a ser avaliado, pois pode interferir na eficiência do tratamento, uma vez que os resultados apresentam-se favoráveis aos pacientes mais jovens, já que o crescimento mandibular favorece a correção da má oclusão de Classe ${ }^{73}{ }^{73}$. O crescimento mandibular em pacientes jovens (média de idade 12,5 anos) e do gênero feminino corrige em até $70 \%$ essa má oclusão, sendo que apenas 30\% da correção provêm da movimentação ortodôntica ${ }^{73}$. A mesma compatibilidade foi observada nas idades finais e conseqüentemente, no tempo de tratamento (Tabela 3, p.107).

Os pacientes pertencentes à amostra totalizaram um número de 30 , sendo 15 do gênero masculino e 15 do gênero feminino; deste modo, a divisão perfeita entre os gêneros sugeriu a compatibilidade, o que foi confirmado a partir de um teste $t$ de Student; sendo assim, essa variável não influenciou os resultados obtidos (Tabela 4, p. 108).

A má oclusão de Classe II tem sido estudada desde os primórdios da Ortodontia, e desde então, desenvolvem-se diversos métodos de tratamento com o intuito de aprimorar técnicas, resultados e principalmente, a fim de controlar ativamente o tratamento sem depender da cooperação do paciente. Os distalizadores intrabucais têm sido um avanço na Ortodontia atuando efetivamente na correção da relação molar de Classe II; contudo, apesar do 
eficiente desempenho na distalização dos molares superiores, como qualquer aparelho ortodôntico, os distalizadores também promovem alguns efeitos indesejáveis que serão discutidos a seguir.

\subsubsection{Alterações Dentárias e Esqueléticas}

As alterações decorrentes da distalização por meio de distalizadores intrabucais podem ser amenizadas ou agravadas a partir de uma série de variáveis pertencentes à metodologia, dentre elas: quantidade de força dissipada, eficiência do reforço de ancoragem, severidade da má oclusão de Classe II, presença e nível de irrupção dos segundos e terceiros molares superiores. Diversos estudos clínicos e científicos demonstram distintos resultados $3,18-20,23-26,30-32,46,50,53,54,58,60,62-65,70,76,82,83,87,96-98,101,103-$

106,113,114,117,118,124,126,127,129,143,147,148,151,157,161,167; portanto, essencial que a metodologia seja avaliada criteriosamente. Os tópicos que individualizam e que influenciam os resultados da distalização podem estar relacionados entre si e serão detalhadamente explicados no decorrer desta discussão.

\subsubsection{Força de Distalização}

Os precursores do distalizador Jones jig ${ }^{96}$, preconizam uma força de dissipação entre 70 a 75 gramas, sendo obtida por meio de uma compressão de 1 a $5 \mathrm{~mm}$ da mola de níquel-titânio. Inúmeros estudos avaliaram o comportamento dentário e esquelético diante desse dispositivo com uma força similar ou até mesmo acima da original e diversos foram os resultados observados $^{23,70,76,96,118,127,143}$.

A força de distalização certamente influencia na distalização linear e na angulação distal dos molares superiores, assim como na quantidade de perda de ancoragem, que se reflete em mesialização e angulação mesial dos prémolares, protrusão dos incisivos superiores e aumento do trespasse horizontal.

Sob uma força média de 120 gramas, a distalização linear para este estudo foi de, em média, 1,59mm para o primeiro molar superior e 1,37mm para o segundo molar superior (Figura 6.1). Esses resultados mostraram-se inferiores a estudos prévios relacionados ao distalizador Jones jig ${ }^{23,70,76,143}$ e a 
outros distalizadores $20,24-26,32,60,87,97,101$, provavelmente por diferenças quanto à metodologia empregada, que pode diferir quanto à quantidade de força dissipada, à qualidade do reforço de ancoragem, à presença dos segundos molares superiores e à severidade da Classe II. Provavelmente, a menor distalização dos molares superiores esteja relacionada à severidade da Classe II, visto que, a maioria dos pacientes apresentava de $1 / 4$ a $1 / 2$ Classe II, portanto, menor foi a quantidade necessária de distalização (Tabela 6, p. 112).

A distalização linear apresentou uma correlação significante e positiva quanto ao comportamento em relação à PTV-1, PTV-5, PTV-7 e PP-6; ou seja, as alterações lineares de molares, pré-molares e incisivos mostraram-se correlacionadas, o que representa que a distalização dos molares ocorre simultaneamente à mesialização dos pré-molares e incisivos, assim como à movimentação vertical dos molares distalizados (Tabela 10, p. 115).

Os estudos referentes ao distalizador Jones jig quando comparados a outros dispositivos intrabucais, demonstraram menor quantidade de distalização. Provavelmente, essa diferença é resultado da quantidade de força dissipada. Geralmente, o distalizador Jones jig atua com uma força média de 75 gramas $^{23,76,143}$, valor esse inferior aos trabalhos que avaliam outros distalizadores, como o pendulum ${ }^{24-26,60,101}$ e o distal jet ${ }^{18,126}$.

Nos estudos de Runge; Martin; Bukai ${ }^{143}$, Haydar; Uner ${ }^{76}$, Gulati; Kharbanda; Parkash $^{70}$ e Brickman ${ }^{23}$ a distalização não ultrapassou $3 \mathrm{~mm}$. Contudo, outro fator, que varia constantemente nesses estudos e que está relacionado à quantidade final de distalização, é o tempo de tratamento.

Gulati; Kharbanda; Parkash ${ }^{70}$, em 1998, distalizando molares superiores com o Jones jig, sob uma força de $150 \mathrm{~g}$, obtiveram uma distalização final de 2,75mm em 3 meses, ou seja, sob uma maior força e em um curto tempo de tratamento, a discrepância corrigida foi menor que uma relação de $1 / 2$ Classe II. Portanto, além da força dissipada, outras variáveis como a severidade da Classe II, o tipo de reforço de ancoragem, a presença e o nível de irrupção dos segundos molares superiores interferem nos resultados finais da distalização.

Ngantung $^{126}$ e Bolla ${ }^{18}$ avaliaram os efeitos do distal jet e demonstraram uma distalização de $2,1 \mathrm{~mm}( \pm 1,8)$ em 6,7 meses $( \pm 1,7)$ e $3,2 \mathrm{~mm}( \pm 1,4)$ em 5 meses, respectivamente, sendo que a força de distalização foi de $240 \mathrm{~g}$. Portanto, observa-se uma maior quantidade de distalização em um tempo de 
tratamento próximo ao deste trabalho. Provavelmente, o aumento da força dissipada interferiu nos resultados finais desses estudos ${ }^{18,126}$.

Os resultados da distalização dos estudos de Keles; Sayinsu ${ }^{101}$, Byloff ${ }^{26}$, Bussick; McNamara ${ }^{24}$, Fuziy ${ }^{58}$, Gosh; Nanda ${ }^{60}$, Chiu; McNamara; Franchi ${ }^{32}$ também demonstraram que o aumento da força dissipada (230g, 200 - 250g, $200-250 \mathrm{~g}, 250 \mathrm{~g}, 230 \mathrm{~g}, 230 \mathrm{~g}$, respectivamente) resulta em maior quantidade de distalização $(5,23 \mathrm{~mm}, 4,1 \mathrm{~mm}, \quad 5,7 \mathrm{~mm}, \quad 4,6 \mathrm{~mm}, \quad 3,4 \mathrm{~mm}, \quad 6,1 \mathrm{~mm}$, respectivamente).

A força de distalização associada à qualidade do reforço de ancoragem também influencia na quantidade de angulação dos molares e pré-molares superiores, como ocorreu neste estudo, em que se observou angulação distal tanto no primeiro como no segundo molar superior (SN.7 e SN.6, respectivamente) e angulação mesial dos segundos pré-molares superiores (SN.5) (Tabela 5, p. 109) (Figura 6.1).

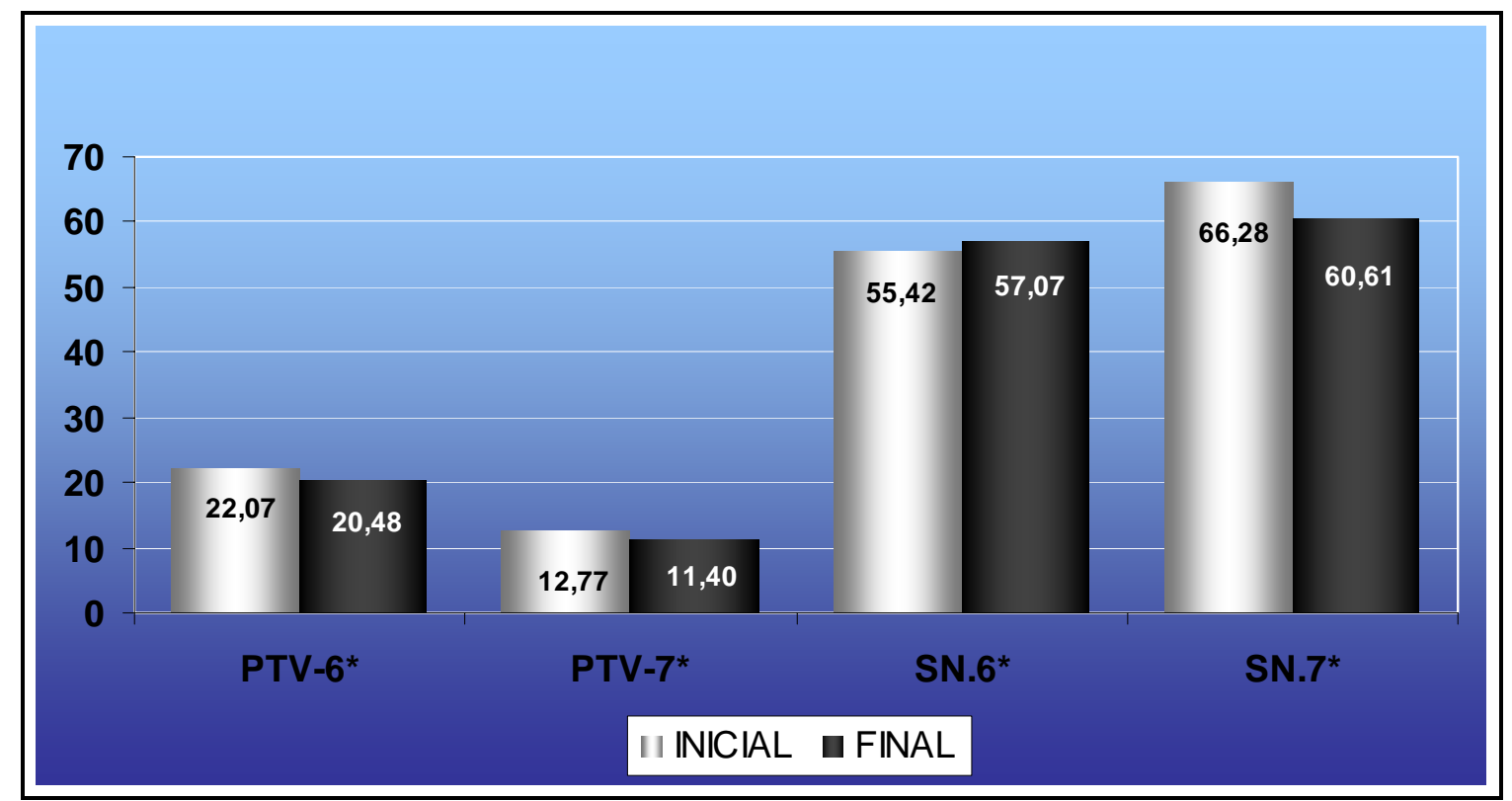

* estatisticamente significante

FIGURA 6.1 - Gráfico com valores iniciais e finais das variáveis que representam as alterações dos primeiros e segundos molares superiores

Diversos estudos comprovam a existência desse movimento indesejável $^{23-25,60,76,97}$. Neste estudo, o posicionamento inicial do primeiro molar 
superior foi de $77,61^{\circ}$ e ao final da distalização $69,03^{\circ}$, sendo uma angulação em média de $8,6^{\circ}$.

Já o segundo molar apresentou um movimento pendular de $5,7^{\circ}$, sendo inicialmente $66,28^{\circ}$ e posteriormente $60,61^{\circ}$; esses resultados mostraram-se similares a outros estudos da literatura ${ }^{23,60,76}$, porém, alguns demonstraram maiores $^{24,25,97}$ e outros menores angulações ${ }^{26,70,143}$. Certamente, essa diferença de resultados relaciona-se à metodologia empregada; como a diferença na quantidade de força dissipada para a distalização, a severidade da discrepância ântero-posterior, a presença ou não dos segundos molares superiores, assim como seu nível de irrupção.

Os estudos de Bussick; McNamara ${ }^{24}$, Joseph; Butchard ${ }^{97}$ e Byloff; Darendeliler $^{25}$ apresentam maiores angulações certamente por avaliarem os efeitos decorrentes da distalização com o aparelho pendulum, cuja força dissipada corresponde a 200 a 250 gramas, sugerindo que uma força exacerbada resulta em maior angulação coronária distal dos molares superiores.

As menores angulações podem estar relacionadas às individualidades pertencentes à metodologia, como demonstra Byloff et al. $^{26}(1997)$ em um estudo realizado para avaliar os efeitos dentários e esqueléticos decorrentes do distalizador pendulum. A princípio Byloff; Darendeliler ${ }^{25}$, em 1997, a partir de 13 pacientes, avaliaram cefalometricamente os efeitos dentários e esqueléticos do aparelho pendulum sem dobras de verticalização e observaram uma angulação distal dos primeiros molares superiores de $14,5^{0^{25}}$. Em um segundo estudo ${ }^{26}$, utilizaram uma amostra de 20 pacientes com média de idade de 13,11 anos e observaram que dobras de verticalização quando inseridas às molas de TMA e adaptadas aos primeiros molares superiores resultam maior movimento de corpo, isto é, menor angulação distal $\left(6,1^{\circ}\right)$.

Em um estudo realizado por Gulati; Kharbanda; Parkash ${ }^{70}(1998)$ que avaliou as alterações dentárias e esqueléticas do Jones jig; observaram que mesmo utilizando uma força de distalização de 150 gramas, ou seja, acima da quantidade original, a angulação distal dos molares e mesial dos pré-molares foi menor, certamente, porque o reforço de ancoragem fora suportado por quatro pré-molares; o que difere do presente estudo, no qual dissipou-se uma força média de 120 gramas, porém, somente os segundos pré-molares foram 
utilizados para cimentação do botão de Nance. Não há na literatura, estudos científicos comparando a qualidade do reforço de ancoragem quando apoiado em dois ou quatro pré-molares. Contudo, seguindo-se o raciocínio de que os dentes permanentes por apresentarem raízes de melhor qualidade, demonstram maior efetividade como suporte da distalização. Sendo assim, especula-se que o número de dentes suporte pode influenciar na quantidade e qualidade da distalização.

No trabalho de Runge; Martin; Bukai ${ }^{143}$ a angulação dos primeiros molares distalizados foi de $4^{\circ}$, valor esse inferior a este estudo. Certamente, a menor angulação é resultado de uma suave força dissipada pelo Jones jig, $70 \mathrm{~g}$ para cada lado, sendo considerada pelos autores, como ativação ótima.

O ideal é que o processo de distalização ocorra por um movimento de corpo, no entanto, não é o efeito geralmente observado, já que os molares distalizados normalmente apresentam um movimento pendular, ou seja, associada à distalização linear ocorre uma angulação dos dentes superiores. Torna-se lícito afirmar que esse resultado está diretamente relacionado a diversos fatores, no entanto, a força dissipada influencia assiduamente sobre o movimento de distalização.

\subsubsection{Reforço de Ancoragem}

A mesialização e angulação mesial dos pré-molares, assim como a protrusão dos incisivos superiores, alterações essas que representam a perda de ancoragem, demonstraram-se estatisticamente significantes neste estudo, com movimentações de $3,26 \mathrm{~mm}, 10,18^{\circ}$ e $1,65 \mathrm{~mm}$, respectivamente, não sendo, porém, significante para a angulação anterior dos incisivos superiores; embora a correlação de Pearson tenha sido significante para SN.1 e SN.5, demonstrando que quanto maior a angulação do segundo pré-molar, maior é a vestibularização do incisivo (Tabela 11, p. 116) (Figura 6.2). 


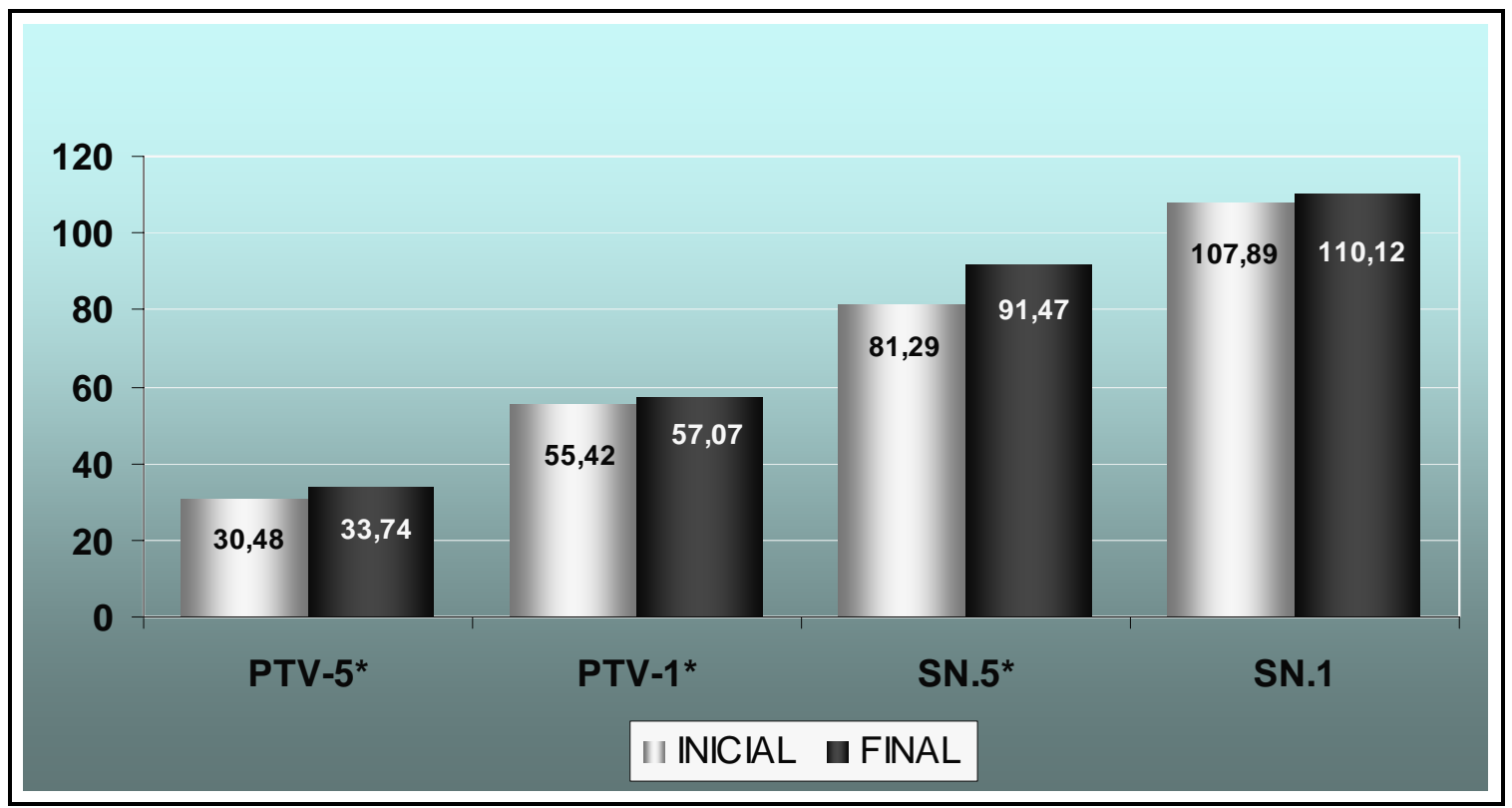

* estatisticamente significante

FIGURA 6.2 - Gráfico das variáveis que representam os dentes de ancoragem

A mesialização dos pré-molares e protrusão dos incisivos superiores estão diretamente relacionadas à eficiência do reforço de ancoragem, porém a quantidade de força dissipada também pode provocar resultados insatisfatórios quanto à perda de ancoragem, já que, existe um fenômeno de ação e reação ao corrigir a Classe II por meio de distalizadores intrabucais. Confirma-se que diante de uma força de 80 gramas não se torna necessário utilizar um dispositivo de ancoragem ${ }^{61}$, porém, não é o que demonstra os resultados de Mavropoulos et al. ${ }^{118}$ (2005) em que diante de 80 gramas de força para cada lado, mesmo com reforço de ancoragem inserido nos pré-molares observaram uma protrusão dos incisivos superiores de 1,9mm.

A maioria dos trabalhos demonstra perda de ancoragem, no entanto, esse efeito é menor em relação ao presente estudo. Poderia atribuir esse resultado à diferença na força de distalização, já que estudos que avaliaram os efeitos do Jones jig demonstraram menor perda de ancoragem diante de uma menor força de distalização ${ }^{76,143}$; por outro lado, para alguns experimentos ${ }^{24-}$ 26,60,70 a força dissipada fora maior que a média de 120 gramas empregada nesta pesquisa, invalidando a hipótese de que quanto maior a força de distalização maior a perda de ancoragem. Portanto, torna-se lícito afirmar que diminuir a força de distalização não garante amenizar a movimentação anterior 
de pré-molares e incisivos. Desta forma, observa-se que, para uma mesma força de distalização, a perda de ancoragem poderia ser menor a partir de um adequado reforço de ancoragem.

Ao contrário das afirmações acima, neste estudo a mesialização dos pré-molares $(3,26 \mathrm{~mm})$ e protrusão dos incisivos $(1,65 \mathrm{~mm})$ foi menor em relação aos resultados de Keles; Sayinsu ${ }^{101}$ (2000), em que um distalizador denominado IBMD (distalizador intrabucal de corpo de molar) com 230 gramas de força fora avaliado; seu reforço de ancoragem consistiu de um bloco de acrílico estendendo-se do palato aos incisivos superiores com um plano de mordida anterior a fim de desocluir os dentes posteriores e facilitar a distalização. Apesar da maior extensão palatina, esse reforço de ancoragem fora fixado apenas nos primeiros pré-molares, o que provavelmente tenha provocado a significante mesialização $(4,33 \mathrm{~mm})$, angulação $\left(2,73^{\circ}\right)$ e extrusão $(3,33 \mathrm{~mm})$ dos pré-molares, assim como a protrusão $(4,7 \mathrm{~mm})$ e inclinação vestibular $\left(6,73^{\circ}\right)$ dos incisivos superiores.

A movimentação dos pré-molares pode variar de acordo com 0 dispositivo empregado para a distalização, ou seja, ao contrário da maioria dos distalizadores, estudos observaram que o distal jet provoca perda de ancoragem, isto é, mesialização dos pré-molares ${ }^{18,126}$; contudo, ocorre uma angulação distal desses dentes de ancoragem. Esse efeito é resultado, provavelmente, do "design" desse distalizador ${ }^{18,126}$, ou seja, devido à resistência do palato duro, a força de distalização pode ser transferida ao braço lingual posicionado superiormente no distal jet, rotacionando os dentes de ancoragem e resultando em angulação distal da coroa dos pré-molares superiores. Porém, a partir de uma mecânica diferenciada, o mesmo efeito ocorre durante a distalização por meio do aparelho extrabucal, ou seja, os prémolares acompanham o movimento distal dos molares superiores, evitando que movimentos indesejados tenham que ser corrigidos, o que favorece 0 tempo de tratamento; no entanto, para alcançar a relação molar normal é necessária cooperação do paciente, o que nem sempre é satisfatória resultando, conseqüentemente, em maior tempo de tratamento ${ }^{31,76}$.

Como conseqüência da perda de ancoragem, geralmente ocorre um aumento no trespasse horizontal como demonstrado pela maioria dos autores $^{23,24,60,70,101,158}$ e significante para este estudo (1,10mm) (Figura 6.3). Em 
uma pesquisa realizada por Bussick; McNamara ${ }^{24}$ observam-se alterações significantes relacionadas à perda de ancoragem, como: aumento no trespasse horizontal, protrusão dos lábios superior e inferior e fechamento do ângulo nasolabial; neste estudo, essas alterações também foram observadas, embora apenas o trespasse horizontal e a protrusão do lábio inferior apresentaram-se significantes. Provavelmente, menores alterações tenham ocorrido nessa pesquisa, porque o tempo de tratamento fora menor em relação ao estudo de Bussick; McNamara ${ }^{24}$.

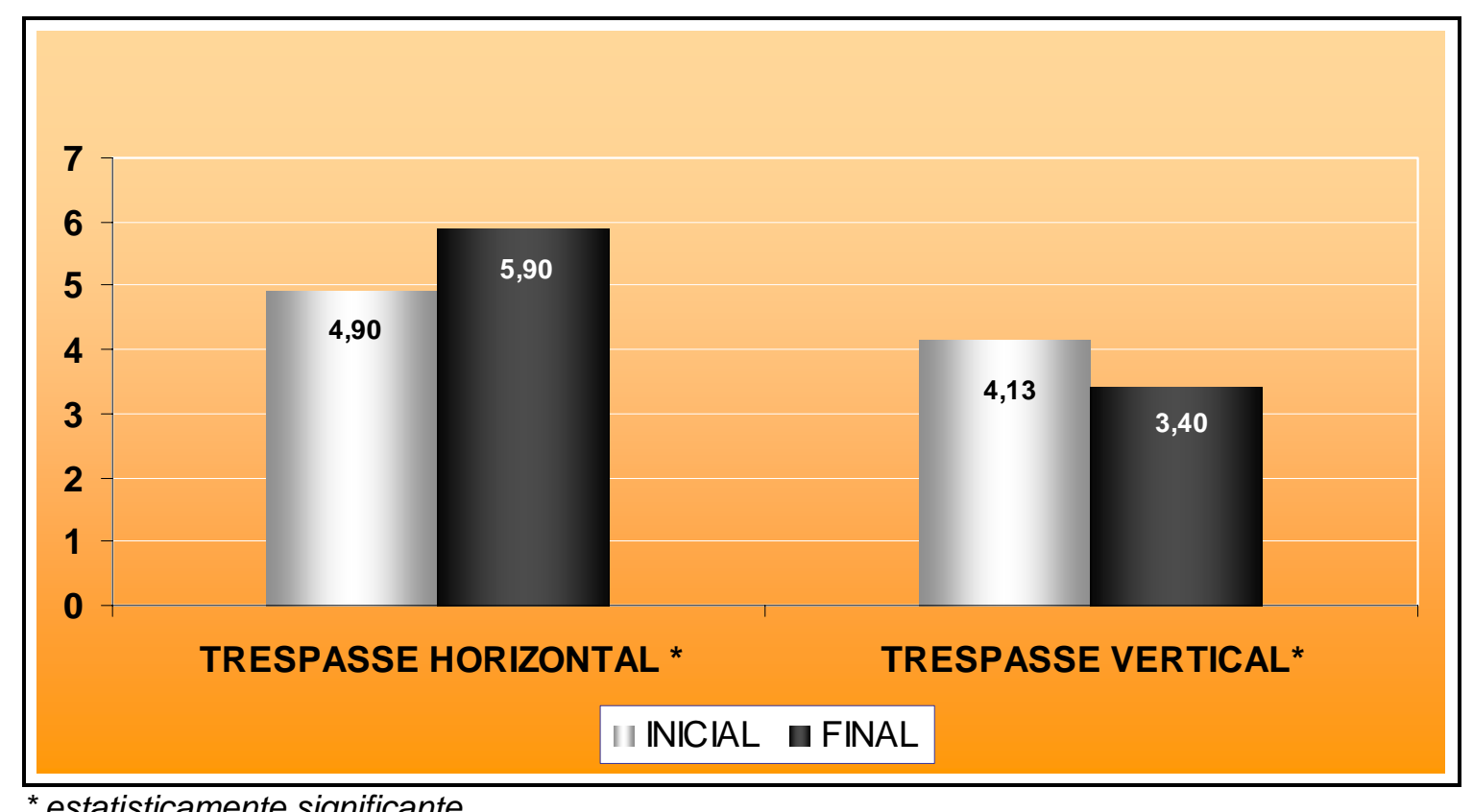

FIGURA 6.3 - Gráfico das alterações do trespasse horizontal e vertical

Gianelly ${ }^{62}$ afirma que diante de um trespasse horizontal, cujo aumento mensal ultrapasse $2 \mathrm{~mm}$, recomenda-se a utilização de elásticos de Classe II com 100 gramas de força associados a uma placa lábio-ativo (PLA) no arco inferior, a fim de auxiliar como reforço de ancoragem, mantendo o posicionamento dos incisivos e evitando uma significante perda de ancoragem e protrusão anterior. Portanto, o reforço de ancoragem é essencial para alcançar resultados satisfatórios na correção da Classe II diante de um tratamento com distalizadores intrabucais. A força dissipada pelos diversos distalizadores pode variar entre 70 e 250 gramas. Sendo que o ideal é que o reforço de ancoragem seja suficiente para suportar a força recíproca da distalização $0^{104,118}$. 
O reforço de ancoragem pode ser inserido nos segundos molares decíduos, primeiros e/ou segundos pré-molares. Obviamente, quanto maior o número de dentes de suporte para ancoragem, menores serão os efeitos indesejáveis, como angulação mesial dos dentes de ancoragem, protrusão dos incisivos, aumento do trespasse horizontal e maior apinhamento ânterosuperior $^{104}$. Alguns estudos na literatura ortodôntica comprovam que a efetividade da ancoragem não depende somente do tecido mucoso e sim da qualidade dos dentes de suporte. O potencial de ancoragem desses dentes é determinado pelo tamanho da ancoragem assim como pelo número de dentes envolvidos, pela topografia e nível de inserção radicular, pela estrutura óssea. Afirma-se que a estrutura óssea e o nível de inserção radicular pouco variam entre crianças e adolescentes; no entanto, podem ocorrer diferenças significantes em relação ao número de dentes e topografia radicular ${ }^{104}$.

A efetividade dos segundos molares decíduos, como reforço de ancoragem, quando comparados aos pré-molares é claramente inferior, visto que fisiologicamente, a longo prazo, a superfície radicular passa por um processo de reabsorção, o que compromete a qualidade do reforço de ancoragem provocando mobilidade e possível remoção do aparelho prematuramente. Portanto, torna-se visível a superioridade dos dentes permanentes em relação aos molares decíduos ${ }^{104}$.

O reforço de ancoragem suportado por segundos molares decíduos ou pré-molares superiores também pode diferir quanto ao comportamento mandibular, ou seja, uma ancoragem realizada a partir de dentes permanentes resulta em aumento significante na altura facial ântero-inferior, maiores alterações no trespasse vertical e maior reposicionamento mandibular posterior, portanto, esses movimentos resultam em uma rotação pósteroinferior da mandíbula ${ }^{24,60}$. O mesmo foi observado neste estudo, em que o reforço de ancoragem esteve apoiado em segundos pré-molares e a observação dos resultados demonstrou uma alteração estatisticamente significante da AFAl, ou seja, um aumento em média de 2,12mm. (Tabela 5, p. 109) (Figura 6.6) Porém, não se pode generalizar essa alteração, já que alguns estudos seguiram considerações similares quanto ao reforço de ancoragem e mesmo diante de inclinações dos planos palatino, oclusal ou mandibular, a AFAI não apresentou aumento significante ${ }^{23,126}$. 
Em um estudo realizado por Patel et al. $^{1}$ (2006) comparou-se os distalizadores Jones jig e pendulum e observou-se que uma distalização efetiva e similar para ambos os distalizadores, no entanto, observou-se uma diferença significante na angulação mesial dos dentes de ancoragem (9,29 ; 2,37 respectivamente); certamente essa discrepante alteração decorre de variações no reforço de ancoragem. O botão de Nance utilizado no grupo do Jones jig caracterizou-se por menor extensão de acrílico e suporte em apenas dois prémolares, enquanto que a ancoragem para a distalização com o pendulum fora suportada por quatro pré-molares

Portanto, observa-se como demonstrado nesta pesquisa, que ocorre maior angulação mesial dos dentes de suporte diante de um reforço insuficiente de ancoragem.

O estudo de Runge; Martin; Bukai ${ }^{143}$ também confirma esses resultados, pois o reforço de ancoragem composto apenas pelos segundos pré-molares, apresentou uma angulação mesial estatisticamente significante ao final da distalização, alterando de $76,53^{\circ}$ para $86^{\circ}$, ou seja, $9,47^{\circ}$ de perda de ancoragem.

Outra forma de aprimorar a qualidade do reforço de ancoragem, sugerida por alguns autores ${ }^{60,101,104}$, seria o aumento da extensão de acrílico apoiada ao palato, no entanto, maiores seriam as chances de provocar injúrias ao tecido mucoso. Portanto, o botão de Nance utilizado neste estudo não ultrapassou 20mm de diâmetro, comportando-se de acordo com as considerações de Runge; Martin; Bukai ${ }^{143}$, para o qual um mínimo de $15 \mathrm{~mm}$ seria o suficiente para suportar as forças de distalização.

Uma terceira opção para reforçar a ancoragem, seria por meio de miniimplantes inseridos na região do palato duro, portanto, é possível que se tenha uma ancoragem intrabucal estável sem apresentar elementos dentários incorporados diretamente. Alguns casos clínicos estudados têm apresentado a associação do distalizador pendulum e implantes palatinos ${ }^{27}$ ou ainda microparafusos e distal-jet ${ }^{99}$, os quais oferecem alternativas favoráveis como meio de ancoragem, promovem distalização efetiva dos molares superiores e

\footnotetext{
${ }^{1}$ Patel MP, Janson G, Henriques JFC, Almeida RR,Freitas, MR, Pinzan, A, Freitas KMS. Comparative distalization of the Jones jig and the pendulum appliances. Am $\mathrm{J}$ Orthod Dentofacial Orthop - enviado para publicação
} 
permitem estabilidade quanto aos movimentos rotacionais. Essa associação não representa somente uma melhora na qualidade do reforço de ancoragem, mas também permite uma ancoragem estável com o arco transpalatino durante a fase de retração dos dentes anteriores. Essa alternativa vem aos poucos evoluindo, no entanto, ainda é considerada atípica para a maioria dos pacientes, como por exemplo, no desenvolvimento desta pesquisa, visto que aumentaria o custo financeiro e possivelmente inviabilizaria a realização deste estudo. Portanto, esse método de ancoragem seria indicado para casos específicos como pacientes adultos com deficiência no suporte periodontal ou ainda pacientes na dentadura mista com perda precoce dos molares decíduos $^{104}$.

\subsubsection{Posicionamento Dentário Vertical}

A irrupção normal dos molares superiores na faixa etária de 11 a 12 anos durante uma observação de quatro meses é de aproximadamente $0,23 \mathrm{~mm}$ quando o plano palatino é utilizado como referência ${ }^{139}$. Observou-se, ao início do tratamento, o posicionamento vertical dos segundos e primeiros molares, segundos pré-molares e incisivos superiores $(12,19 \mathrm{~mm} ; 16,96 \mathrm{~mm}$; $18,90 \mathrm{~mm}$ e $26,21 \mathrm{~mm}$ respectivamente) que corresponde à medida vertical entre o plano palatino perpendicular ao ponto central da coroa desses dentes. Baseando-se em estudos ${ }^{23,60,126}$ cuja metodologia é similar a esta apresentada, comprovou-se que os valores encontrados estão de acordo com os pacientes avaliados em estudos prévios (10,26mm; 16,87mm; 19,29mm; 27,96mm ${ }^{23}$; $(11,21 \mathrm{~mm} ; 17,25 \mathrm{~mm} ; 19,12 \mathrm{~mm} ; 28,43 \mathrm{~mm})^{126} ;(10,55 \mathrm{~mm} ; 17,77 \mathrm{~mm} ; 20,89 \mathrm{~mm}$; $27,94 \mathrm{~mm})^{60}$.

A força de distalização, normalmente, provoca um efeito intrusivo dos primeiros molares superiores ${ }^{24-26,103}$, porém nem sempre estatisticamente significante ${ }^{60,126}$, mas de maneira geral, clinicamente significante, como observado nos resultados deste estudo (Tabela 5, p. 109) e na alteração média esquematizada a partir dos 30 pacientes pertencentes a esta amostra representada esquematicamente pela Figura 6.4. Porém, para outros autores, 
ocorre um comportamento inverso, isto é, extrusão dos primeiros e segundos molares superiores ${ }^{23,32,70,76,101}$.

Embora, para este estudo, a intrusão dos primeiros molares superiores não seja significante, (0,26mm - Tabela 5, p. 109), alguns autores observam resultados estatisticamente significantes ${ }^{25,58}$. Esse efeito pode estar diretamente relacionado à acentuada angulação desses dentes, o que posiciona o centro da coroa mais próximo do plano palatino. Já a extrusão não significante dos segundos molares superiores $(0,18 \mathrm{~mm}-$ Tabela 5, p. 109) pode representar um desenvolvimento vertical normal; embora, segundo Riolo et al. ${ }^{139}$ para a faixa etária de 13 a 14 anos ocorre normalmente $1 \mathrm{~mm}$ de irrupção. Portanto, atribui-se o menor resultado deste estudo à combinação de alterações verticais e angulares, uma vez que a angulação acentuada decorrente da distalização, impede um desenvolvimento irruptivo normal.
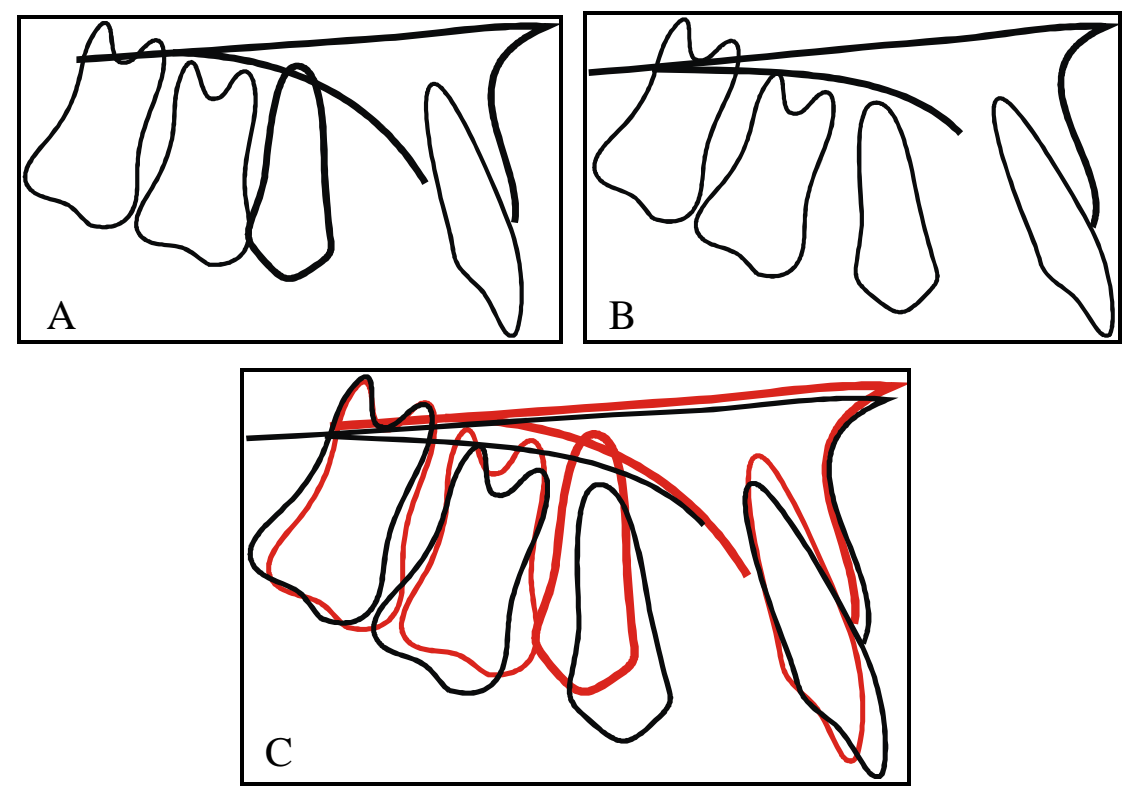

FIGURA 6.4 - Média das alterações dentoalveolares: A) inicial;

B) pós-distalização; C) sobreposição inicial x final

A alteração marcante na maioria dos artigos refere-se à extrusão dos dentes de suporte, o que representa a perda de ancoragem e está diretamente relacionada às considerações realizadas anteriormente a respeito da qualidade 
e quantidade de dentes suporte para reforço da ancoragem. Portanto, certamente, esse efeito indesejável é decorrente da força mesial recíproca à distalização, assim como à exacerbada angulação mesial e ao insuficiente reforço de ancoragem, já que para um avantajado botão de Nance e um maior número de dentes de suporte, a perda de ancoragem é menor ${ }^{60,104}$.

Embora para alguns trabalhos essa alteração não se mostrasse significante ${ }^{32,103,126}$, os resultados deste estudo corroboram com outros autores $^{23,57,58,60,101}$ em que a extrusão dos pré-molares foi estatisticamente significante $(1,68 \mathrm{~mm})$ (Figura 6.5).

Observações longitudinais comprovam que a extrusão, a angulação mesial dos pré-molares e a inclinação anterior dos incisivos superiores são efeitos revertidos durante o tratamento ativo com o aparelho fixo superior ${ }^{23,76}$ ou mesmo espontaneamente no período de verticalização e estabilização com o botão de Nance posicionado nos molares distalizados ${ }^{101}$.

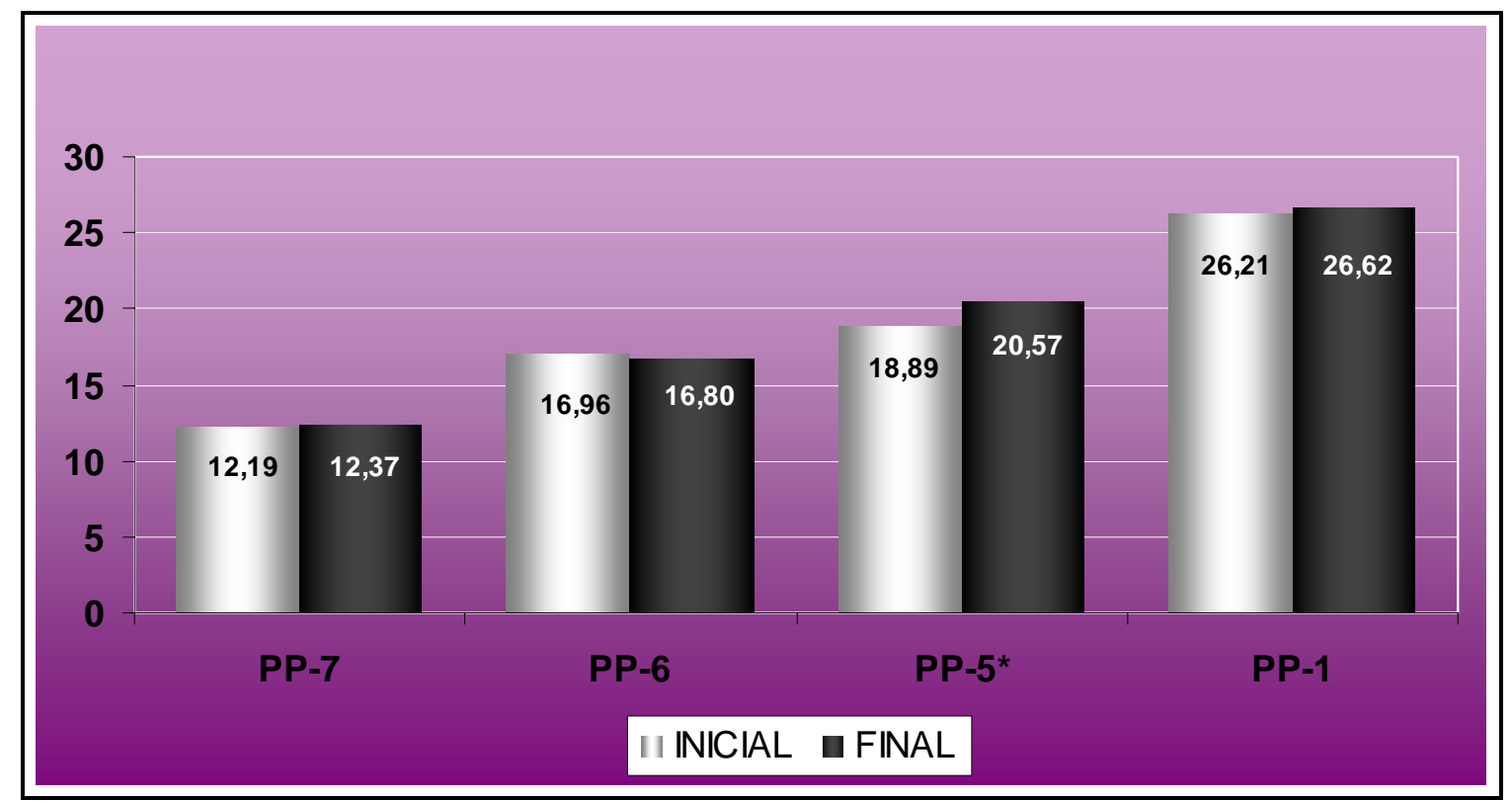

* estatisticamente significante

FIGURA 6.5 - Gráfico das alterações no sentido vertical dos molares, prémolares e incisivos superiores

As alterações esqueléticas ocorridas após a distalização com dispositivos intrabucais, podem ser atribuídas às movimentações dentárias que resultam em alterações de estruturas ósseas (Figura 6.6). Alguns estudos 
observam aumento significante na altura facial ântero-inferior decorrente da extrusão dentária superior ou inferior o que resulta em rotação mandibular posterior e que podem ou não levar a alterações significantes do trespasse vertical $^{24,32,158}$, como demonstrou o teste de correlação de Pearson, no qual primeiros e segundos molares e pré-molares superiores apresentaram correlação positiva significante variando entre forte e média, ou seja, as movimentações verticais foram proporcionais às alterações esqueléticas(Tabela 11, p. 116). Portanto, sugere-se que a extrusão significante dos dentes de ancoragem relaciona-se ao aumento das grandezas cefalométricas, NS.Gn e AFAI, o que conseqüentemente resulta na diminuição do trespasse vertical $(0,73 \mathrm{~mm})$. Apesar de os molares inferiores não terem sido avaliados, é provável que não apresentassem resultados significantes, já que SN.GoGn que poderia demonstrar essas alterações, não se alterou significantemente.

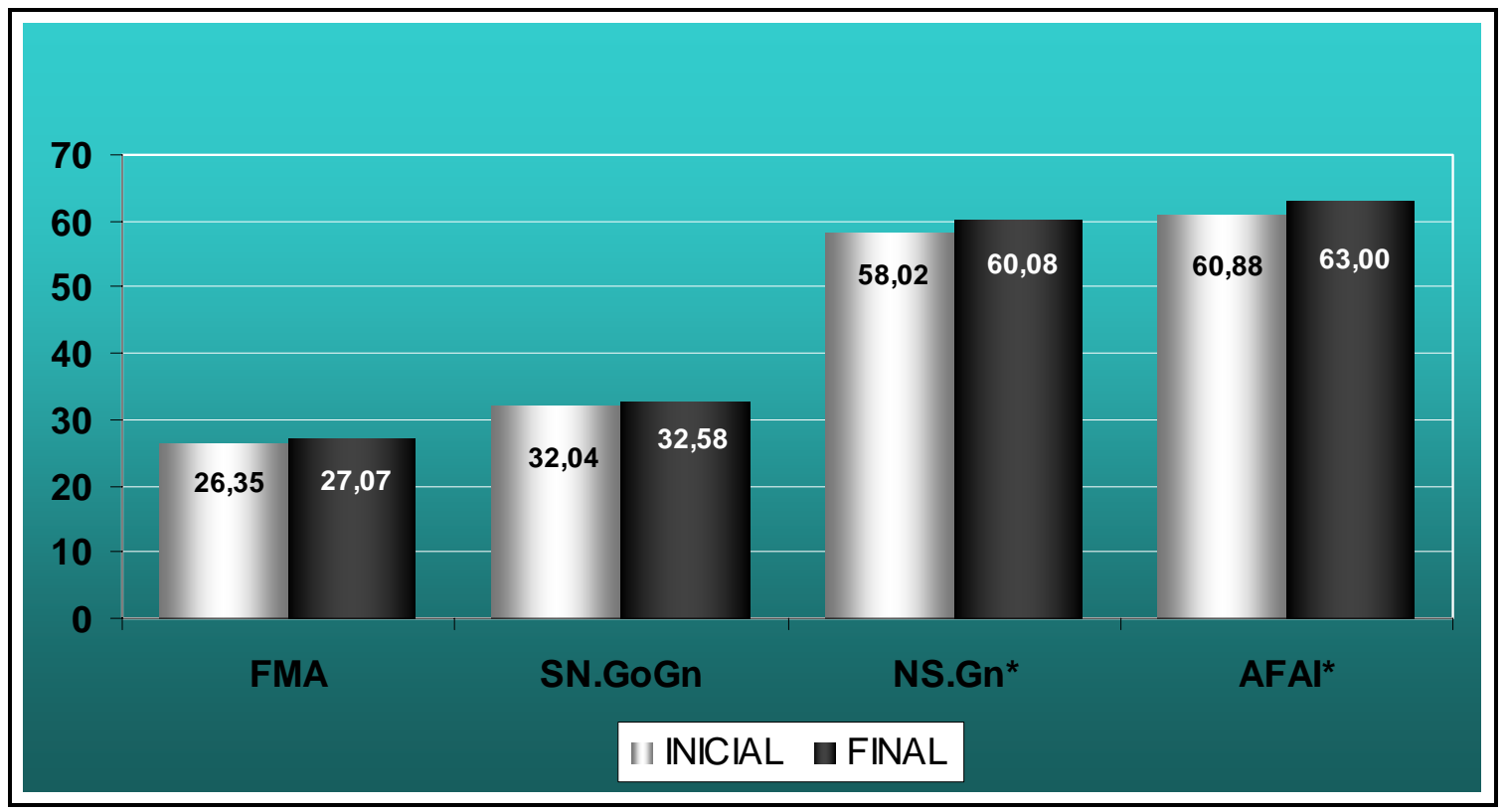

* estatisticamente significante

FIGURA 6.6 - Gráfico das variáveis relacionadas ao padrão cefálico, valores inciais e finais à distalização 


\subsubsection{Severidade da Má Oclusão de Classe II}

Certamente, a severidade da discrepância ântero-posterior influencia no tempo de tratamento, na quantidade de distalização dos molares superiores e na perda de ancoragem. Portanto, é imprescindível determinar a severidade da má oclusão a ser tratada. Embora alguns autores ${ }^{57,58,126,127}$ quantifiquem essa má oclusão, a maioria dos estudos que se referem a distalizadores intrabucais ${ }^{18,24-26,30,32,50,60,70,76,96,97,113,118,143,158}$, de uma forma geral, não relatam a severidade da Classe II; desta forma, análises comparativas podem ser erroneamente realizadas, uma vez que a quantidade de distalização diferencia resultados finais; da mesma forma, é correto afirmar que o sucesso do tratamento da má oclusão da Classe II varia de acordo com a severidade inicial da discrepância ântero-posterior ${ }^{88,165}$. Neste estudo, descreveu-se a severidade da má oclusão de Classe II, sendo 1/4 (30\%), 1/2(40\%), 3/4 (16,7\%) e completa (13,3\%); de acordo com o posicionamento da cúspide mésio-vestibular do molar superior em relação ao molar inferior ${ }^{8}$. (Tabela 6, p. 112) (Figura 6.7)

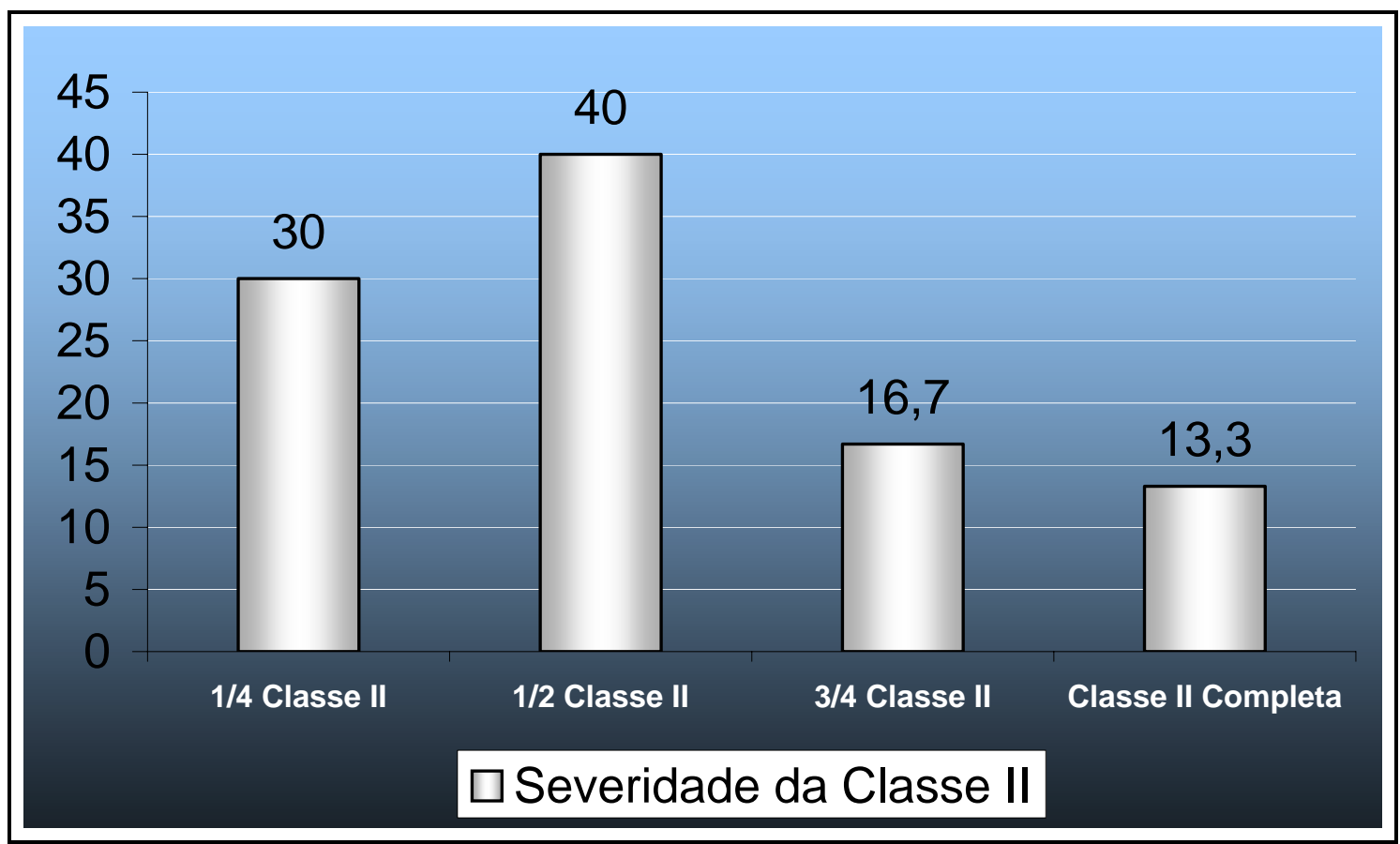

FIGURA 6.7 - Gráfico da distribuição dos pacientes quanto à má oclusão de Classe II 
Alguns autores afirmam que o tipo de Classe II dentária pode influenciar os efeitos obtidos com o emprego do distalizador Jones jig, visto que esse dispositivo apresenta melhor indicação no tratamento de uma Classe II dentária menos severa ${ }^{76,127,157}$.

Portanto, a fim de não gerar dúvidas quanto à influência da severidade dessa má oclusão nos resultados da distalização, avaliou-se as alterações a partir de pacientes com até $1 / 2$ Classe II e observou-se que apenas o segundo molar superior (PTV-7) e o lábio inferior (E-Li) comportaram-se de forma semelhante; porém, não apresentaram significância estatística como nos resultados anteriores. As demais variáveis demonstraram alterações similares a todos os outros pacientes. Portanto, para este estudo a severidade da má oclusão de Classe II não interferiu nos resultados finais na distalização dos primeiros molares superiores com o Jones jig (Tabela 7, p. 112).

Justifica-se a protrusão não significante do lábio inferior, porque paciente com severa má oclusão de Classe II apresenta maior discrepância ânteroposterior, portanto, a quantidade de distalização será maior e movimentos como extrusão de molares e pré-molares e rotação mandibular serão mais pronunciados e evidentes, o que conseqüentemente afetará o posicionamento do lábio inferior. Já para uma Classe II menos severa, esses efeitos podem ser amenizados e ocorrerá pouca alteração no posicionamento labial inferior? ${ }^{7}$.

\subsubsection{Presença dos Segundos Molares Superiores}

A influência dos segundos molares superiores na distalização dos primeiros molares é considerada uma controvérsia na literatura. Alguns autores têm comprovado que a presença dos segundos molares aumenta o tempo de tratamento ${ }^{63,64}$, resulta em maior angulação ${ }^{18,20}$ e maior perda de ancoragem ${ }^{18,103}$; sendo que diante do germe do terceiro molar superior, a angulação do segundo molar aumenta ${ }^{103}$; portanto, recomenda-se a germectomia desse dente, o que resultaria em um movimento de corpo tanto do primeiro como do segundo molar superior. Por outro lado, outros confirmam que a presença e a posição dos segundos molares não interferem na qualidade e quantidade da distalização ${ }^{24,25,124}$. Neste estudo, observou-se que a presença 
dos segundos molares não interferiu significantemente na movimentação linear de pré-molares e molares superiores, nem na perda de ancoragem dos prémolares; no entanto a angulação distal dos molares distalizados foi significantemente maior em pacientes cujo segundo molar superior apresentouse parcialmente irrompido (Tabela 8, p. 114), corroborando com estudos prévios $^{18,20,103}$.

A presença dos segundos e terceiros molares podem influenciar na quantidade da distalização, na angulação dos primeiros molares superiores e diante de uma movimentação simultânea de primeiros e segundos molares, a força dissipada seria maior, conseqüentemente, a perda de ancoragem também poderia ser agravada.

O germe dentário presente na direção do movimento distal atua como um fulcro, o que resulta em maior angulação dos dentes distalizados. Comprovou-se essa afirmação a partir de um estudo realizado por Kinzinger ${ }^{103}$ (2004) em que 36 adolescentes submetidos à distalização com o aparelho pendulum foram divididos em três grupos distintos de acordo com o grau de irrupção dos segundos e terceiros molares: grupo 1, segundos molares aquém do plano oclusal ou em estágio de formação; grupo 2, segundos molares completamente desenvolvidos e terceiros molares em estágio de formação; grupo 3, germectomia dos terceiros molares na presença de primeiros e segundos molares completamente irrompidos. Observou-se que os molares distalizados demonstraram maior angulação diante de germes dentários localizados distalmente e aquém do plano oclusal. Esse fenômeno pode ser justificado pelo posicionamento do centro de resistência, ou seja, o germe do segundo molar age como um obstáculo no movimento distal, dessa forma, o centro de resistência tende a se movimentar superiormente e pode resultar em maior angulação ${ }^{18,68}$.

Portanto, a fim de evitar ou diminuir esse movimento indesejável, podese lançar mão da germectomia dos terceiros molares, sendo assim, os primeiros e segundos molares movimentam-se de corpo, mesmo sem esses últimos estarem bandados. Contudo, se os quatro molares forem distalizados simultaneamente, em conseqüência, a quantidade de distalização será menor e aumentará a perda de ancoragem ${ }^{103}$. 
A distalização simultânea de primeiros e segundos molares não exige que a força dissipada seja maior, no entanto, a porcentagem de distalização em relação a outros estudos ${ }^{24,25,103,104,106}$ diminui consideravelmente, sendo que para um espaço total de 6,1mm, apenas 2,8mm (46\%) representa a distalização dos molares superiores; portanto, conseqüentemente, o espaço restante entre molares e pré-molares, corresponde à perda de ancoragem representada pela mesialização e angulação dos pré-molares e caninos e inclinação vestibular e protrusão dos incisivos superiores ${ }^{118}$.

Os resultados da distalização também podem ser influenciados de acordo com o período de intervenção ortodôntica, ou seja, pacientes na fase de dentadura permanente apresentam valores de distalização e angulação dos molares superiores menores do que pacientes com dentadura mista, para os quais o movimento mesial dos incisivos é mais pronunciado ${ }^{104}$. Esse processo pode ser explicado a partir do estágio diferenciado de irrupção dos segundos molares, isto é, esses dentes em processo inicial de formação atuam como um fulcro para os molares a serem distalizados e representam menor resistência ao movimento de distalização. Contudo, diante de um desenvolvimento radicular avançado e completa irrupção dos segundos molares superiores, o ponto de contato entre os molares superiores é deslocado coronariamente, em conseqüência, os primeiros molares distalizam sob maior resistência, porém reduz-se a tendência de angulação. Dessa forma, a quantidade de distalização é menor e torna-se maior o movimento mesial do segmento anterior ${ }^{104}$.

\subsubsection{Tempo de Tratamento}

O tempo de tratamento para a terapia com distalizadores intrabucais é extremamente relativo, pois pode alterar de acordo com a discrepância ânteroposterior, presença dos segundos molares superiores e efetividade do reforço de ancoragem. Para a maioria dos estudos, o distalizador Jones jig corrige a relação molar de Classe II em um tempo médio de quatro meses ${ }^{54,70,76,96,118}$. Porém, alguns trabalhos ${ }^{23,143}$ demonstram um maior tempo para correção da Classe II (6,4 e 6,2 meses, respectivamente); ou seja, próximo ao tempo despedido neste estudo; certamente, o tempo de tratamento com distalizadores 
intrabucais é influenciado por diversas variáveis como a força dissipada para a distalização, a severidade da Classe II, a dificuldade em sobrecorrigir a relação molar e a interferência distal na movimentação dos primeiros molares devido à presença dos segundos molares superiores.

No entanto, o tempo ligeiramente maior, resultante deste estudo pode ser justificado pelo período dedicado à sobrecorreção e pela ocorrência de algumas fraturas da ligadura que comprime a mola de distalização (Tabela 1 e 3, p. 74 e 107).

Dessa forma, justifica-se a pequena quantidade de distalização ao mês, ou seja, o maior tempo de tratamento refletiu em uma média de correção mensal inferior a estudos prévios ${ }^{18,57,58,83,96,103}$, sendo assim, esse resultado interfere na efetividade do distalizador Jones jig, pois a distalização média ocorreu em um longo período de tempo (Tabela 9, p. 114). Contudo, em uma análise clínica, observou-se uma evolução relativamente rápida na distalização dos molares superiores, principalmente em pacientes com menor discrepância ântero-posterior e sem os segundos molares totalmente irrompidos.

Gosh; Nanda ${ }^{60}$ (1996) avaliaram os efeitos do aparelho pendulum e observaram que $57 \%$ do espaço entre molares e pré-molares superiores, correspondeu à distalização dos molares, sendo 43\% a perda de ancoragem, representada por mesialização dos pré-molares. Porém, Chiu; McNamara; Franchi $^{32}$ obtiveram, empregando o mesmo dispositivo, 19\% de perda de ancoragem. O trabalho de Bolla et al. ${ }^{18}$ que avaliaram os efeitos do distal jet, a distalização correspondeu a $71 \%$ e $29 \%$ de perda de ancoragem.

Já os estudos que analisaram as alterações provenientes do distalizador Jones jig, a proporção entre distalização e perda de ancoragem foi semelhante. Para Brickman; Sinha; Nanda ${ }^{23} 55 \%$ do espaço criado, correspondeu à distalização dos primeiros molares, resultados que se aproximam do trabalho de Gosh; Nanda ${ }^{60}$. No estudo de Haydar; Uner ${ }^{76}$, a perda de ancoragem foi quantificada em 55\% do espaço entre molares e pré-molares. Para Runge; Martin Bukai ${ }^{143}$ o espaço foi proporcionalmente dividido, ou seja, 50\% de perda de ancoragem e 50\% de distalização. Já Gulati; Kharbanda; Parkash ${ }^{70}$ que utilizaram uma força de $150 \mathrm{~g}$, obtiveram apenas $26 \%$ de perda de ancoragem.

Para este estudo, a porcentagem de distalização (38\%) foi extremamente inferior aos estudos prévios ${ }^{24-26,32,58,60,97,103-106}$, sendo a perda de 
ancoragem $62 \%$, desta forma, a partir de todas as considerações realizadas anteriormente, observa-se que para este estudo a força dissipada para a distalização dos molares superiores foi acima do ideal e o reforço de ancoragem utilizado não foi adequado para manter a força recíproca à distalização, ou por apresentar insuficiente tamanho do acrílico ou por estar ancorado em apenas dois pré-molares.

\subsubsection{Alterações do Perfil Facial}

Os distalizadores intrabucais, especificamente o Jones jig, é um aparelho designado para correção da Classe II dentária, no entanto, como já foram observadas, algumas movimentações dentoalveolares refletem em estruturas esqueléticas que resultam alterações no perfil facial.

Os precursores ${ }^{96}$ do distalizador Jones jig não relatam modificações no perfil mole, no entanto, observaram uma mínima movimentação para anterior dos incisivos superiores que poderia ser refletida ao perfil facial, sendo agravada quando na associação do dispositivo intrabucal ao aparelho fixo superior. Essa mesma protrusão dos incisivos superiores foi observada nos estudos de Runge; Martin; Bukai ${ }^{143}$ (1999) e determinada como perda de ancoragem e esteve associada a um aumento da altura facial ântero-inferior, o que provavelmente resultou nos efeitos indesejáveis como aumento na projeção dos lábios superior e inferior de 0,38mm e 1,0mm, respectivamente.

Ao contrário do resultado observado neste estudo, isto é, protrusão do lábio inferior $(-0,58 \mathrm{~mm})$, a maioria dos estudos que avaliam o comportamento do perfil facial demonstra que o lábio inferior sofre uma retrusão, que aumenta com o avanço da idade dos indivíduos ${ }^{13,136}$.

Sugere-se que a protrusão do lábio inferior relacione-se às alterações do esqueleto cefálico, isto é, observa-se que houve um aumento significante de NS.Gn e AFAl, ou seja, uma possível rotação para baixo e para trás da mandíbula. Dessa forma, o plano estético ${ }^{136}$ também pode ter sofrido alteração, sendo posicionado posteriormente, o que demonstra protrusão do lábio inferior, resultante não do posicionamento labial e sim por uma alteração do plano de referência. 


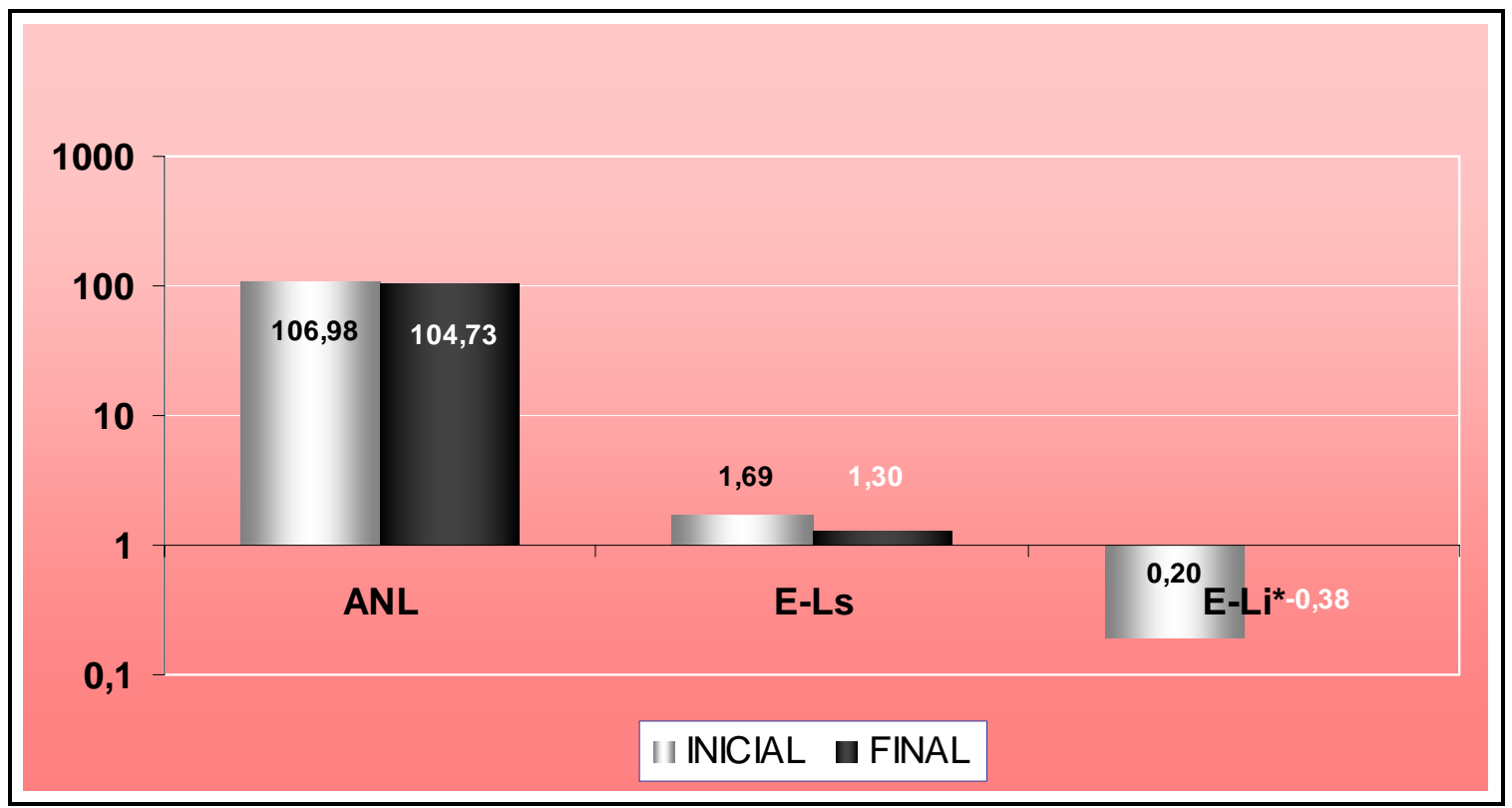

*estatisticamente significante

FIGURA 6.8 - Gráfico das alterações do perfil mole após a fase de distalização dos molares superiores

\subsection{Implicações Clínicas}

A Classe II é uma má oclusão discutida há décadas e diversos autores apresentaram diversificados métodos de tratamento, no entanto, a característica peculiar ao sucesso do tratamento corresponde à cooperação do paciente, o que nem sempre é satisfatória. Desta forma, intensifica-se a utilização dos distalizadores intrabucais, que demonstram resultados positivos a partir de uma mínima colaboração do paciente, ou seja, é possível que se tenha maior controle do tratamento, no entanto, o paciente continua sendo fundamental para o sucesso do tratamento.

Diversos métodos de distalização intrabucal têm sido difundidos, sendo que o mecanismo de ação pouco difere entre eles; destacam-se pela eficiente distalização dos molares superiores a partir de uma ancoragem intrabucal. Os resultados podem ser influenciados por certas características pertencentes ao paciente e à metodologia, como a época de intervenção, a idade inicial, a severidade da má oclusão, o método de ancoragem e a força dissipada; porém, em geral, atuam de forma rápida, eficaz e são bem aceitos pelos pacientes. 
O distalizador Jones jig, particularmente, diante da experiência clínica, é um dispositivo fácil de ser manuseado, porém, desprende um prolongado tempo de instalação, principalmente, na fase de confecção do reforço de ancoragem. Relativamente, é um aparelho de alguns casos de quebra e poucas queixas por injúria à mucosa jugal.

Durante a fase de distalização, o sucesso do tratamento é praticamente garantido; contudo após corrigir a relação molar, é imprescindível a cooperação do paciente na utilização do aparelho extrabucal a fim de verticalizar o dente distalizado, já que os molares se movimentam basicamente por angulação distal, tornando-se necessário corrigir o posicionamento radicular. Em virtude da verticalização dos molares superiores, deve-se sobrecorrigir a relação molar, com o intuito de se evitar, posteriormente, uma recidiva da má oclusão de Classe II, o que prolongaria ainda mais o tempo de tratamento.

Em suma, o processo de distalização promove certos efeitos indesejáveis, que futuramente devem ser corrigidos e que podem prolongar o tempo de tratamento na intervenção com o aparelho fixo ${ }^{6,130}$. Desta forma, propomos avaliar o tempo para a completa correção da Classe II tratada por meio do distalizador Jones jig previamente ao aparelho fixo; assim como avaliar e comparar as alterações decorrentes de diferentes métodos intrabucais para corrigir a relação molar de Classe II. 
Conclustes 



\section{CONCLUSÕES}

Com base na metodologia empregada e a partir dos resultados obtidos, possibilitou-se avaliar as alterações dentárias e esqueléticas durante a distalização por meio do aparelho Jones jig, portanto pode-se concluir que:

\subsection{Efeitos Esqueléticos:}

7.1.1 Não houve alterações esqueléticas significantes na maxila;

7.1.2 Ocorreu rotação mandibular horária, representada pelo aumento das variáveis NS.Gn e AFAI.

\subsection{Distalização dos Molares Superiores:}

7.2.1 Os primeiros e segundos molares ao fim da distalização resultaram em alterações linear, angular e vertical, sendo que, apenas a distalização e a angulação distal demonstraram significância estatística;

7.2.2 A distalização mensal dos primeiros molares superiores foi numericamente inferior à mesialização dos segundos pré-molares.

7.2.3 A presença dos segundos molares superiores não interferiu significantemente na quantidade da distalização, contudo, influenciou o comportamento angular dos primeiros molares distalizados;

\subsection{Comportamento dos Dentes de Ancoragem}

7.3.1 Os dentes de ancoragem, ou seja, os segundos pré-molares movimentaram-se significantemente de forma linear, angular e vertical; ou seja, demonstrou-se a significante perda de ancoragem diante da mesialização, angulação mesial e extrusão desses dentes;

7.3.2 Os incisivos superiores, que refletem indiretamente o comportamento do reforço de ancoragem, apresentaram apenas uma significante 
protrusão, sendo certamente o fator determinante para o aumento do trespasse horizontal ao final da distalização.

7.3.3 A extrusão significante dos segundos pré-molares provavelmente foi a alteração responsável pela rotação horária da mandíbula, o que resultou nos aumentos significantes do trespasse vertical e da altura facial ântero-inferior; consequentemente na protrusão significante do lábio inferior;

\subsection{Analisar a correlação entre as variáveis dentárias e esqueléticas}

7.4.1 De forma geral, observou-se que as variáveis dentárias e esqueléticas correlacionam-se entre si demonstrando alterações significantes. 


$$
\begin{aligned}
& \text { Referéncias } \\
& \text { Bibliograficas }
\end{aligned}
$$





\section{REFERÊNCIAS BIBLIOGRÁFICAS}

1. Aidar L, Scanavini M. Estudo comparativo cefalométrico radiográfico dos padrões de crescimento facial em pacientes portadores e oclusão normal e más oclusões de Classe I, Classe II, divisão 1, Classe II, divisão 2 e Classe III de Angle, de acordo com Siriwat \& Jarabak. Ortodontia. 1989;22:31-52.

2. Allan T, Hodgson E. The use of personality measurements as a determinant of patient cooperation in an orthodontic practice. Am J Orthod. $1968 ; 54(6): 433-40$.

3. Almeida MR, Almeida RR, Insabralde CMB. Um método alternativo de tratamento para a correção de Classe II de Angle utilizando o aparelho de Jones Jig. Relato de um caso clínico. Rev Dent Press Ortodon Ortopedi Facial. 1999;4(4):37-44.

4. Almeida R, Almeida M, Fuziy A, Henriques J. Modificação do aparelho Pendulum/Pend-x. Descrição do aparelho e técnica de construção. Rev Dent Press Ortodon Ortopedi Facial. 1999;4(6):12-9.

5. Andreasen G, Naessig C. Experimental findings on mesial relapse of maxillary first molars. Angle Orthod. 1968;38(1):51-5.

6. Angelieri F. Avaliação cefalométrica pós-distalização relizada por meio do aparelho pendulum, em pacientes em tratamento ortodôntico com aparelho fixo. [mestrado]. Bauru: Faculdade de Odontologia de Bauru - Universidade de São Paulo; 2002.

7. Angle E. Classification of malocclusion. Dent Cosmos. 1899;41(3):24864.

8. Angle E. Treatment of malocclusion of the teeth. Philadelphia: SSWhite; 1907.

9. Araújo M. Contribuição ao estudo dos desvios ântero-posteriores da mandíbula através das radiografias cefalométricas (Nos casos de Classe I e 
Classe II) [livre docência]. Piracicaba: Faculdade de Odontologia de Piracicaba; 1964.

10. Armstrong M. Controlling the magnitude, direction, and duration of extraoral force. Am J Orthod. 1971;59(3):217-43.

11. Baalack IB, Poulsen A. Occipital anchorage for distal movement of the maxillary first molars. Acta Odont Scand. 1966;24(3):307-25.

12. Baumrind S, Frantz RC. The reliability of head film measurements. 1. Landmark identification. Am J Orthod. 1971;60(2):111-27.

13. Bishara SE. Mandibular changes in persons with untreated and treated Class II division 1 malocclusion. Am J Orthod Dentofacial Orthop. 1998;113(6):661-73.

14. Bishara SE, Jakobsen JR, Hession TJ, Treder JE. Soft tissue profile changes from 5 to 45 years of age. Am J Orthod Dentofacial Orthop. 1998;114(698-706).

15. Bishara SE, Peterson LC, Bishara EC. Changes in facial dimensions and relationships between the ages of 5 and 25 years. Am J Orthod. 1984;85(3):238-52.

16. Bjerin R. A comparision between the Frankfort horizontal and the sella turcica-nasion as reference planes in chephalometric analysis. Acta Odont Scand. 1957;15(1):1-12.

17. Björk A. The face in profile: an anthropological x-ray investigation on Swedish children and conscripts. Am J Orthod. 1948;34:619-29.

18. Bolla E, Muratore F, Carano A, Bowman SJ. Evaluation of maxillary molar distalization with the distal jet: a comparison with other contemporary methods. Angle Orthod. 2002;72(5):481-94.

19. Bondemark L, Kurol J. Distalization of maxillary first and second molars simultaneously with repelling magnets. Eur J Orthod. 1992;14(4):264-72. 
20. Bondemark L, Kurol J, Bernhold M. Repelling magnets versus superlastic nickel titanium coils simultaneous distal movement of maxilary firt and second molars. Angle Orthod. 1994;64:189-98.

21. Bowman SJ. Class II combination therapy. J Clin Orthod. 1998;32(10):611-20.

22. Bowman SJ. Class II combination therapy (distal jet and Jasper Jumpers): a case report. J Orthod. 2000;27(3):213-8.

23. Brickman CD, Sinha PK, Nanda RS. Evaluation of the Jones jig appliance for distal molar movement. Am J Orthod Dentofacial Orthop. 2000;118(5):526-34.

24. Bussick TJ, McNamara JA, Jr. Dentoalveolar and skeletal changes associated with the pendulum appliance. Am J Orthod Dentofacial Orthop. 2000;117(3):333-43.

25. Byloff FK, Darendeliler MA. Distal molar movement using the pendulum appliance. Part 1: Clinical and radiological evaluation. Angle Orthod. 1997;67(4):249-60.

26. Byloff FK, Darendeliler MA, Clar E, Darendeliler A. Distal molar movement using the pendulum appliance. Part 2: The effects of maxillary molar root uprighting bends. Angle Orthod. 1997;67(4):261-70.

27. Byloff FK, Karcher H, Clar E, Stoff F. An implant to eliminate anchorage loss during molar distalization: a case report involving the Graz implantsupported pendulum. Int J Adult Orthodon Orthognath Surg. 2000;15(2):129-37.

28. Carano A, Testa M, Rotunno E. Corrección de la Clase II con el Distal Jet. Rev Esp Ortod. 1999;29:139-44.

29. Carano A, Testa M, Siciliani G. The Distal Jet for uprighting lower molars. J Clin Orthod. 1996;30(12):707-10.

30. Carano A, Testa M, Siciliani G. The lingual distalizer system. Eur J Orthod. 1996;18(5):445-8. 
31. Cetlin NM, Ten Hoeve A. Nonextraction treatment. J Clin Orthod. 1983;17(6):396-413.

32. Chiu PP, McNamara JA, Jr., Franchi L. A comparison of two intraoral molar distalization appliances: distal jet versus pendulum. Am J Orthod Dentofacial Orthop. 2005;128(3):353-65.

33. Chung K, Park Y, Ko S. C- space regainer for molar distalization. J Clin Orthod. 2000;34(1):32-9.

34. Clemmer E, Hayes E. Patient cooperation in wearing orthodontic headgear. Am J Orthod. 1979;75(5):517-24.

35. Coben S. Growth and Class II treatment. Am J Orthod. 1971;59(1):5-26.

36. Coelho CM, Filho. Mandibular protraction appliances for Class II treatment. J Clin Orthod. 1995;29(5):319-36.

37. Coelho CM, Filho. O Aparelho de Protração Mandibular IV. R Dental Press Ortod Ortop Facial. 2002;7(2):49-60.

38. Costa LA, Suguino R. Aparelho de Protração Mandibular:uma nova abordagem na confecção do aparelho. Rev Dent Press Ortodon Ortopedi Facial. 2006;4(6):16-29.

39. Craig CE. The skeletal patterns characteristic of Class I and Class II, Division I malocclusions in norma lateralis. Angle Orthod. 1951;21(1):44-56.

40. Crawford T. A multiple regression analysis of patient cooperation during orthodontic treatment. Am J Orthod. 1974;65(4):436-7.

41. Creekmore TD. Inhibition or stimulation of the vertical growth of facial complex, its significance to treatment. Angle Orthodont. 1967;37(4):285-97.

42. Cruz KS, Henriques JFC, Dainesi EA, Janson G. Efeitos dos aparelhos funcionais na correção da má oclusão de Classe II. Rev Dent Press Ortodon Ortopedi Facial. 2000;5(4):43-52. 
43. Dahlberg G. Statistical methods for medical and biological students. New York: Interscience; 1940.

44. Dorsey J, Korabik K. Social and psychological motivations for orthodontic treatment. Am J Orthod. 1977;72(4):460.

45. Downs WB. Variation in facial relationships: Their significance in treatment and prognosis. Am J Orthod. 1948;34(9):812-40.

46. Echarri P, Scuzzo G, Cirulli N. A modified pendulum appliance for anterior anchorage control. J Clin Orthod. 2003;37(7):352-9.

47. Elsasser W, Wylie W. The craniofacial morphology of mandibular retrusion. Amer J Phys Anthropol. 1948;6:461-74.

48. Enlow DH, Kuroda $\mathrm{T}$, Lewis $\mathrm{AB}$. The morphological and morphogenetic basis for craniofacial form and pattern. Angle Orthod. 1971;41(3):161-88.

49. Erverdi N, Koyuturk O, Kucukkeles N. Nickel-titanium coil springs and repelling magnets: a comparison of two different intra-oral molar distalization techniques. Br J Orthod. 1997;24(1):47-53.

50. Figueiredo C, Figueiredo M, Nobuyasu M. Distalização de molares superiores com aparelho Pendulum/Pendx. Rev Assoc Paul Cir Dent. 1999;53:27-30.

51. Fisk G, Culbert M, Grainger R, Hemrend B, Moyers R. The morphology and physiology of distocclusion. Am J Orthod. 1953;35:3-12.

52. Foley TF, Mamandras AH. Facial growth in females 14 to 20 years of age. Am J Orthod Dentofacial Orthop. 1992;101(3):248-54.

53. Fortini A, Lupoli M, Giuntoli F, Franchi L. Dentoskeletal effects induced by rapid molar distalization with the first class appliance. Am J Orthod Dentofacial Orthop. 2004;125(6):697-704. 
54. Freitas BV. Distalização unilateral de primeiros molares superiores com o aparelho Jones jig. Apresentação de dois casos clínicos. Ortodontia. 1995;28(3):31-40.

55. Freitas M, Freitas D, Pinheiro F, Freitas K. Prevalência das más oclusões em pacientes inscritos para tratamento ortodôntico na Faculdade de Odontologia de Bauru - USP. Rev Fac Odontol Bauru. 2002;10(3):164-9.

56. Freitas PA. Telerradiografia - filtro para desracar o perfil de partes moles. Bol Soc Paul Ortod. 1966;2:17-9.

57. Fuziy A. Estudo das alterações sagitais, verticais e transversais decorrentes da distalização dos molares superiores com o aparelho Pendulum. [doutorado]. Bauru: Faculdade de Odontologia de Bauru - Universidade de São Paulo; 2001.

58. Fuziy A, Almeida RR, Janson G, Angelieri F, Pinzan A. Sagittal, vertical, and transverse changes consequent to maxillary molar distalization with the pendulum appliance. Am J Orthod Dentofacial Orthop. 2006;130:502-10.

59. Ghafari J. Modified Nance and lingual appliances for unilateral tooth movement. J Clin Orthod. 1985;19(1):30-3.

60. Ghosh J, Nanda RS. Evaluation of an intraoral maxillary molar distalization technique. Am J Orthod Dentofacial Orthop. 1996;110(6):639-46.

61. Giancotti A, Cozza P. Nickel titanium double-loop system for simultaneous distalization of first and second molars. J Clin Orthod. 1998;32(4):255-60.

62. Gianelly A. Distal movement of the maxillary molars. Am J Orthod Dentofacial Orthop. 1998;114(1):66-72.

63. Gianelly AA, Bednar J, Dietz VS. Japanese NiTi coils used to move molars distally. Am J Orthod Dentofacial Orthop. 1991;99(6):564-6.

64. Gianelly AA, Vaitas AS, Thomas WM. The use of magnets to move molars distally. Am J Orthod Dentofacial Orthop. 1989;96(2):161-7. 
65. Gianelly AA, Vaitas AS, Thomas WM, Berger DG. Distalization of molars with repelling magnets. J Clin Orthod. 1988;22(1):40-4.

66. Gilmore W. Morphology of the adult mandible in Class II, Division 1 malocclusion and in excellent occlusion. Angle Orthod. 1950;20(3):137-46.

67. Goldreich HN, Martins JCR, Martins LP, Sakima PR. Considerações sobre os erros em cefalometria. Rev Dent Press Ortodon Ortopedi Facial. 1998;3(1):81-90.

68. Graber T. Extraoral force - facts and fallacies. Am J Orthod. 1955;41(7):490-505.

69. Greenfield R. Fixed piston appliance for rapid Class II correction. J Clin Orthod. 1995;29(3):174-83.

70. Gulati S, Kharbanda OP, Parkash H. Dental and skeletal changes after intraoral molar distalization with sectional jig assembly. Am J Orthod Dentofacial Orthop. 1998;114(3):319-27.

71. Hägg $U$, Taranger J. Maturation indicators and the pubertal growth spurt. . Am J Orthod. 1982;82(4):299-309.

72. Harnick D. Case report: Class II correction using a modified Wilson bimetric distalizing arch and maxillary second molar extraction. Angle Orthod. 1998;68(3):275-80.

73. Harris EF, Dyer GS, Vaden JL. Age effects on orthodontic treatment: skeletodental assessments from the Johnston analysis. Am J Orthod Dentofacial Orthop. 1991;100(6):531-6.

74. Harris J, Kowalski C, Walker G. Discrimination between normal and Class II individuals using Steiner's analysis. Angle Orthod. 1972;42(3):212-20.

75. Hayasaki SM, Henriques JFC, Janson G, Freitas MR. Influence of extraction and nonextraction orthodontic treatment in Japanese-Brazilians with class I and class II division 1 malocclusions. Am J Orthod Dentofacial Orthop. 2005;127(1):30-6. 
76. Haydar S, Uner O. Comparison of Jones jig molar distalization appliance with extraoral traction. Am J Orthod Dentofacial Orthop. 2000;117(1):49-53.

77. Henriques JFC, Freitas MR, Hayasaki SM. Principais indicações e efeitos da ancoragem extrabucal occipital (IHG) no tratamento de jovens com má oclusão de Classe II, 1a. divisão de Angle: apresentaçào de um caso clínico. Rev Dental Press Ortod Ortop Facial. 1999;4(2):33-8.

78. Henriques JFC, Maltagliati LA, Freitas MR, Jason G, Maltagliati AMA. Utilização do aparelho removível conjugado à ancoragem extrabucal para a correção da má oclusão de Classe II, 1a divisão, com sobremordida profunda. Rev Dental Press Ortod Ortop Facial. 1997;2(2):12-8.

79. Henriques JFC, Maltagliati IA, Pinzan A, Freitas MR. Estudo longitudinaldas características da má oclusão de Classe II 1a divisão, sem tratamento, em jovens brasileiros, leucodermas, por um período médio de 3 anos e 4 meses. Rev Dental Press Ortodon Ortop Fac. 1998;3(3):52-66.

80. Henriques RP. Estudo cefalométrico comparativo das alterações da má oclusão de Classe II, $1^{\text {a }}$ divisão de Angle, em jovens submetidos a dois tipos de ancoragem extrabucal. [mestrado]. Bauru: Faculdade de Odontologia de Bauru - Universidade de São Paulo; 2003.

81. Heydt K. An analysis of the clinical entity, maxillary protrusion, with relation to classification, diagnosis, and treatment. Am $\mathrm{J}$ Orthod. 1951;37(11):842-57.

82. Hilgers J. The Pendulum appliance ... An update. J Clin Impressions. 1993;2(1):15-7.

83. Hilgers JJ. The pendulum appliance for Class II non-compliance therapy. J Clin Orthod. 1992;26(11):706-14.

84. Hitchcock H. A cephalometric description of Class II, division 1 malocclusion. Am J Orthod. 1973;63(4):414-23. 
85. Houston WJ. The analysis of errors in orthodontic measurements. Am J Orthod. 1983;83(5):382-90.

86. Hunter WS. The vertical dimensions of the face and skeletodental retrognathism. Am J Orthod. 1967;53(8):586-95.

87. Itoh T, Tokuda T, Kiyosue S, Hirose T, Matsumoto M, Chaconas SJ. Molar distalization with repelling magnets. J Clin Orthod. 1991;25(10):611-7.

88. Jacobs T, Sawaengkit P. National Institute of Dental and Craniofacial Research efficacy trials of bionator class II treatment: a review. Angle Orthod. 2002;72(6):571-5.

89. Jacobson A. The "Wits" appraisal of jaw disharmony. Am J Orthod. 1975;67(2):125-38.

90. Janson G, Dainesi EA, Henriques JF, Freitas MR, Lima KJ. Class II subdivision treatment success rate with symmetric and asymmetric extraction protocols. Am J Orthod Dentofacial Orthop. 2003;124(3):257-64.

91. Janson G, Maria FR, Barros SE, Freitas MR, Henriques JF. Orthodontic treatment time in 2- and 4-premolar-extraction protocols. Am $\mathrm{J}$ Orthod Dentofacial Orthop. 2006;129(5):666-71.

92. Janson GR, Toruno JL, Martins DR, Henriques JF, Freitas MR. Class II treatment effects of the Frankel appliance. Eur J Orthod. 2003;25(3):301-9.

93. Järvinen S. Saddle angle and maxillary prognathism. A association between the NS.Ar and saddle angles. Br J Orthod. 1984;11(4):209-13.

94. Johnson BE. Distal movement of the maxillary molar using na active removable appliance and extraoral force: a case report. Quintessence Int. 1994;25(1):43-8.

95. Johnson JS. A new approach to cephalometric analysis of the dental base relationship. Angle Orthod. 1978;48(1):23-32. 
96. Jones RD, White JM. Rapid Class II molar correction with an open-coil jig. J Clin Orthod. 1992;26(10):661-4.

97. Joseph AA, Butchard CJ. An evaluation of the pendulum "distalizing" appliance. Semin Orthod. 2000;6:129-35.

98. Kalra V. The K-loop molar distalizing appliance. J Clin Orthod. 1995;29(5):298-301.

99. Karaman Al, Basciftci FA, Polat O. Unilateral distal molar movement with an implant-supported distal jet appliance. Angle Orthod. 2002;72(2):167-74.

100. Keeling SD, Wheeler TT, King GJ, Garvan CW, Cohen DA, Cabassa S, et al. Anteroposterior skeletal and dental changes after early Class II treatment with bionators and headgear. Am J Orthod Dentofacial Orthop. 1998;113(1):4050.

101. Keles A, Sayinsu K. A new approach in maxillary molar distalization: intraoral bodily molar distalizer. Am J Orthod Dentofacial Orthop. 2000;117(1):39-48.

102. Kingsley NW. Orthodontics: an historical review of its origin and evolution. St. Louis: Mosby; 1875.492p.

103. Kinzinger GS, Fritz UB, Sander FG, Diedrich PR. Efficiency of a pendulum appliance for molar distalization related to second and third molar eruption stage. Am J Orthod Dentofacial Orthop. 2004;125(1):8-23.

104. Kinzinger GS, Gross U, Fritz UB, Diedrich PR. Anchorage quality of deciduous molars versus premolars for molar distalization with a pendulum appliance. Am J Orthod Dentofacial Orthop. 2005;127(3):314-23.

105. Kinzinger GSM, Syree C, Fritz UB, Diedrich PR. Molar distalization with different pendulum appliances: in vitro registration of orthodontic forces and moments in the initial phase. J Orofac Orthop. 2004;65(5):389-409. 
106. Kinzinger GSM, Wehrbein H, Diedrich PR. Molar distalization with a modified pendulum appliance--in vitro analysis of the force systems and in vivo study in children and adolescents. Angle Orthod. 2005;75(4):558-67.

107. Klein P. An evaluation of cervical traction on the maxilla and the upper first permanent molar. Angle Orthod. 1957;27(1):61-8.

108. Kloehn SJ. Guiding alveolar growth and eruption of teeth to reduce treatment time and produce a more balanced denture and face. Angle Orthod. 1947;17(11-2):10-33.

109. Krogman W, Sassouni V. A syllabus in roengenographic chephalometric. 2nd ed: Philadelphia College Offset; 1957.45-103.

110. Legan HL, Burstone CJ. Soft tissue cephalometric analysis for orthognathic surgery. J Oral Surg. 1980;38(10):744-51.

111. Lewis D, Fox N. Distal movement without headgear: the use of an upper removable appliance for the retraction of upper first molars. $\mathrm{Br} \mathrm{J}$ Orthod. 1996;23:305-12.

112. Liu YT, Gravely JF. The reliability of the 'Ortho Grid' in cephalometric assessment. $\mathrm{Br}$ J Orthod. 1991;18(1):21-7.

113. Locatelli R, Bednar J, Dietz VS, Gianelly AA. Molar distalization with superelastic NiTi wire. J Clin Orthod. 1992;26(5):277-9.

114. Macedo DM, Aidar LAA. Dispositivos intrabucais fixos para a correção da relação molar de Classe II. Rev Dent Press Ortodon Ortopedi Facial. 2003;8(2):63-72.

115. Maia JE, Oliveira AG, Oliveira GJ, Oliveira JNJ, Silveira CA. Estudo cefalométrico comparativo da inclinação axial mésio-distal dos molares superiores, da altura facial ântero-inferior e do ângulo nasolabial após o emprego de dois sistemas de distalização intrabucal: distal jet e Jones jig. J Bras Ortodon Ortop Facial. 2004;9(50):121-33. 
116. Martins DR, Janson G, Almeida RR, Pinzan A, Henriques JFC, Freitas MR. Atlas de Crescimento Craniofacial. São Paulo: Santos; 1998.

117. Martins J, Melo A, Martins L. "Pendex" modificado: um novo aparelho para distalização dos molares superiores no tratamento da má oclusão de Classe II. J Bras Ortodon Ortop Maxilar. 1996;1(4):37-43.

118. Mavropoulos A, Karamouzos A, Kiliaridis S, Papadopoulos MA. Efficiency of noncompliance simultaneous first and second upper molar distalization: a three-dimensional tooth movement analysis. Angle Orthod. 2005;75(4):532-9.

119. McNamara JA, Jr. Components of class II malocclusion in children 8-10 years of age. Angle Orthod. 1981;51(177-202).

120. Melsen B. Effects of cervical anchorage during and after treatment: an implant study. Am J Orthod. 1978;73(5):526-40.

121. Mills C, Holman G, Graber T. Heavy intermittent cervical traction in Class II treatment: A longitudinal cephalometric assessment. Am J Orthod. 1978;74(4):361-79.

122. Misaka M, Fantini S. Análise telerradiográfica dos componentes da ma oclusão de Classe II, em norma lateral, em crianças brasileiras com idades entre 8 e 12 anos. Ortodontia. 1997;30(3):18-30.

123. Miura F, Mogi M, Ohura Y, Karibe M. The super-elastic Japanese NiTi alloy wire for use in orthodontics. Am $\mathrm{J}$ Orthod Dentofacial Orthop. 1988;94(2):89-96.

124. Muse D, Fillman M, Emmerson W, Mitchell R. Molar and incisor changes with Wilson rapid molar distalization. Am J Orthod Dentofacial Orthop. 1993;104(6):556-65.

125. Nanda RS, Kierl MJ. Prediction of cooperation in orthodontic treatment. Am J Orthod Dentofacial Orthop. 1992;102:15-21. 
126. Ngantung V, Nanda RS, Bowman SJ. Posttreatment evaluation of the distal jet appliance. Am J Orthod Dentofacial Orthop. 2001;120(2):178-85.

127. Oliveira JMM, Eto LF. Avaliação radiográfica dos efeitos do aparelho Jones Jig nas distalizações intrabucais: um estudo piloto. Rev Dent Press Ortodon Ortopedi Facial. 2004;9(5):20-7.

128. Pancherz $\mathrm{H}$. The mechanism of Class II correction in Herbst appliance treatment. A cephalometric investigation. Am J Orthod. 1982;82(2):104-13.

129. Patel MP, Henriques RP, JHenriques JFC, Janson G, Freitas MR. Tratamento da má oclusão de Classe II - parte 1: distalização e contenção dos molares superiores. Rev Assoc Paul Espec Ortod Ortop Facial. 2004;2(4):17277.

130. Pinzan-Vercelino CRM. Comparação entre os graus de eficiência do tratamento da má oclusão de Classe II realizado com o aparelho pendulum e com a extração de dois pré-molares superiores. [doutorado]. Bauru: Faculdade de Odontologia de Bauru - Universidade de São Paulo; 2005.

131. Proffit WR. Forty-year review of extraction frequencies at a university orthodontic clinic. Angle Orthodont. 1994;64(6):407-14.

132. Quick AN, Harris AM. Molar distalization with a modified distal jet appliance. J Clin Orthod. 2000;34(7):419-23.

133. Rana R, Becher M. Class II correction using the Bimetric Distalizing Arch. Semin Orthod. 2000;6(2):106-18.

134. Reina E, Mendoza A. Hexahelix: Distalador intraoral de doble función. Rev Esp Ortodon. 1999;29:17-26.

135. Renfroe E. A study of the facial patterns associated with Class I, Class II, division 1, and Class II, division 2 malocclusions. Angle Orthod. 1948;18(12):12-5.

136. Ricketts RM. Cephalometric synthesis. Am J Orthod. 1960;46(9):647-73. 
137. Ricketts RM. New pwerspectives on orientation and their benefits to clinical orthodontics. Part I. Angle Orthod. 1975;45(4):238-48.

138. Riedel RA. The relation of maxillary structures ti cranium is malocclusion and in normal occlusion. Angle Orthod. 1952;22(3):142-5.

139. Riolo ML, Moyers RE, McNamara JA, Hunter WS. An Atlas of Cranifacial Growth: cephalometric standars from the University School Growth Study. Ann Arbor: The University of Michigan; 1974.379.

140. Rondeau B. The pendulum appliance. J General Orthodon. 1995;6(1):2230.

141. Rosé R. Aplicaciones clínicas del resorte espiral. Distalamiento molar. Sociedad Argent Ortodon. 1992;56(111):55-9.

142. Rosenblum RE. Class II malocclusion: mandibular retrusion or maxillary protrusion? Angle Orthod. 1995;65(1):49-62.

143. Runge ME, Martin JT, Bukai F. Analysis of rapid maxillary molar distal movement without patient cooperation. Am J Orthod Dentofacial Orthop. $1999 ; 115(2): 153-7$.

144. Sandler PJ. Reproducibility of cephalometric measurements. $\mathrm{Br} \mathrm{J}$ Orthod. 1988;15(2):105-10.

145. Sassouni V. The Class II syndrome: differential diagnosis and treatment. Angle Orthod. 1970;40(4):334-41.

146. Schudy FF. The rotation of the mandible resulting from growth: its implications in orthodontic treatment. Angle Orthodont. 1965;35(1):36-50.

147. Scuzzo G, Pisani F, Takemoto K. Maxillary molar distalization with a modified pendulum appliance. J Clin Orthod. 1999;33(11):645-50.

148. Silva E, Gasque C, Vieira A. Ertty System: um novo conceito na distalização de molares. Rev Dent Press Ortodon Ortopedi Facial. 2003;2:4560. 
149. Silva OG, Filho, Artuso ESR, Cavassan AO, Capelozza Filho L. Distalizador "Jones Jig": Um Método Alternativo para a Distalização de Molares Superiores. Rev Dent Press Ortodon Ortopedi Facial. 2000;5(4):18-26.

150. Silva OG, Filho, Freitas SF, Cavassan AO. Prevalência de oclusão normal e má oclusão em escolares da cidade de Bauru (São Paulo). Parte I: relação sagital. Rev Fac Odontol Univ São Paulo. 1990;4(2):130-7.

151. Silveira C, Oliveira G, Oliveira A, Oliveira J. Efeitos Dento-EsqueléticoFaciais da Utilização do Aparelho Distalizador Jones Jig, em Tratamento de Más Oclusões Classe II de Angle. J Bras Ortodon Ortop Facial. 2001;6(31):729.

152. Simplício A. Avaliação dos componentes horizontais e verticais da má oclusão Classe II, $1^{\mathrm{a}}$ divisão (Angle), em pacientes de 8 a 12 anos [mestrado]. Araraquara: Faculdade de Odontologia de Araraquara, Universidade Estadual Paulista.; 1995.

153. Snodgrass DJ. A fixed appliance for maxillary expansion, molar rotation, and molar distalization. J Clin Orthod. 1996;30(3):156-9.

154. Steger ER, Blechman AM. Case reports: molar distalization with static repelling magnets. Part II. Am J Orthod Dentofacial Orthop. 1995;108(5):54755.

155. Steiner $\mathrm{C}$. The use of cephalometrics as an aid to planning and assessing orthodontic treatment. . Am J Orthod. 1960;46:721-35.

156. Steiner C. Ceplalometrics as a clinical tool. Vistas in orthodontics; 1962. p. 131-61.

157. Suguino R, Furquim LZ, Ramos AL. O Aparelho Jones Jig. Rev Dent Press Ortodon Ortopedi Facial. 2000;5(3):83-116.

158. Toroglu M, Uzel I, Çam O, Hancioglu Z. Cephalometric evaluation of the effects of pendulum appliance on various vertical growth patterns and of the changes during short-term stabilization. Clin Orthod Res. 2001;4:15-27. 
159. Tweed $\mathrm{CH}$. The Frankfort mandibular plane angle in orthodontic diagnosis, classification, treatment planning and prognosis. . J Orthod. $1946 ; 32: 175-320$.

160. Ucem TT, Yuksel S, Okay C, Gulsen A. Effects of a three-dimensional bimetric maxillary distalizing arch. Eur J Orthod. 2000;22(3):293-8.

161. Ursi W, Almeida GA. Cooperação mínima utilizando o pêndulo de Hilgers. Rev Dent Press Ortodon Ortopedi Facial. 2002;7(2):87-123.

162. Ursi W, McNamara JA, JR. Crescimento craniofacial em pacientes apresentando más oclusões de Classe II e oclusão normal, entre os 10 e os 12 anos de idade. Rev Dent Press Ortodon Ortopedi Facial. 1997;2(5):49-59.

163. Vale D, Martins D. Avaliação cefalométrica das estruturas dentoesqueléticas em jovens portadores de Classe II, divisão 1, brasileiros, leucodermas e de origem mediterrânea. Ortodontia. 1987;20:5-17.

164. Vigorito JW. Estudo comparativo de algumas características mandibulares em maloclusões de Classe I e Classe II, divisão 1 de Angle. Rev Fac Odontol Univ São Paulo. 1973;11(1):75-82.

165. Wheeler TT, McGorray SP, Dolce C, Taylor MG, King GJ. Effectiveness of early treatment of Class II malocclusion. Am J Orthod Dentofacial Orthop. 2002;121(1):9-17.

166. Wieslander L. Early or late cervical traction therapy of Class II malocclusion in the mixed dentition. Am J Orthod. 1975;67(4):432-9.

167. Wilson W, Wilson R. Modular Orthodontics* (Wilson); 1981.

168. Wilson WL. Modular Orthodontic Systems. Part 2. J Clin Orthod. 1978;12(5):358-75.

169. Wilson WL. Modular Orthodontic systems. Part I. J Clin Orthod. 1978;12(4):259-78. 
170. Zanelato R, Trevisi H, Zanelato A. Extração dos segundos molares superiores. Uma nova abordagem para os tratamentos da Classe II, em pacientes adolescentes. Rev Dent Press Ortodon Ortopedi Facial. 2000;5(2):64-75. 



$$
\text { Apénclice }
$$



Apêndice 1 - Idades inicial e final e tempo de tratamento em anos dos pacientes pertencentes à amostra Jones jig.

\begin{tabular}{|c|c|c|c|}
\hline PACIENTES & IDADE INICIAL & IDADE FINAL & $\begin{array}{c}\text { TEMPO DE } \\
\text { TRATAMENTO }\end{array}$ \\
\hline ALINE C. & 12,28 & 13,07 & 0,79 \\
\hline ANDRÉ R. & 14,57 & 16,00 & 1,43 \\
\hline ARIENE S. & 11,35 & 12,46 & 1,11 \\
\hline BEATRIZ G. & 13,23 & 14,09 & 0,86 \\
\hline BRUNA S. & 13,83 & 14,79 & 0,97 \\
\hline CAMILA S. & 14,69 & 15,71 & 1,02 \\
\hline DAVI M. & 11,86 & 12,68 & 0,82 \\
\hline ERICK B. & 15,26 & 16,23 & 0,97 \\
\hline ERIC R. & 13,63 & 14,61 & 0,97 \\
\hline FERNANDO O. & 13,00 & 13,81 & 0,81 \\
\hline FLÁVIA R. & 14,80 & 15,74 & 0,94 \\
\hline GABRIEL P. & 12,78 & 13,67 & 0,89 \\
\hline GUILHERME F. & 12,31 & 13,05 & 0,74 \\
\hline GUILHERME T. & 13,46 & 14,64 & 1,18 \\
\hline HENRIQUE G. & 13,11 & 13,65 & 0,54 \\
\hline IRIS M. & 13,95 & 14,70 & 0,75 \\
\hline ISABELLE O. & 13,03 & 13,86 & 0,83 \\
\hline JÉSSICA G. & 12,17 & 13,08 & 0,91 \\
\hline JONATHAN H. & 15,06 & 15,47 & 0,41 \\
\hline JOSÉ ORLANDO R. & 14,27 & 14,68 & 0,41 \\
\hline KAROLYNE S. & 15,30 & 15,92 & 0,62 \\
\hline LIVIA S. & 13,77 & 14,57 & 0,81 \\
\hline LUCAS A. & 13,39 & 15,34 & 1,95 \\
\hline LUIZ HENRIQUE T. & 11,65 & 12,47 & 0,82 \\
\hline MICHELE F. & 10,83 & 11,33 & 0,50 \\
\hline PAULO RICARDO R. & 11,84 & 12,42 & 0,58 \\
\hline PRISCILA R. & 11,67 & 12,12 & 0,45 \\
\hline RAFAEL V. & 12,54 & 13,36 & 0,81 \\
\hline TAMARA S. & 13,64 & 14,55 & 0,91 \\
\hline VALESKA B. & 11,64 & 12,33 & 0,69 \\
\hline
\end{tabular}


Apêndice 2 - Dados referentes à avaliação das telerradiografias em norma lateral da fase inicial.

\begin{tabular}{|c|c|c|c|c|c|c|c|c|}
\hline PACIENTES & SN.7 & SN.6 & SN.5 & SN.1 & PTV-7 & PTV-6 & PTV-5 & PTV-1 \\
\hline ALINE C. & 64,4 & 71 & 78,4 & 113,1 & 5,9 & 14,3 & 22,1 & 45,9 \\
\hline ANDRÉ R. & 62 & 74 & 73 & 108,1 & 14,5 & 23,8 & 32,7 & 62,6 \\
\hline ARIENE S. & 78,1 & 77,7 & 80,5 & 107,1 & 20 & 30,1 & 38,8 & 65,4 \\
\hline BEATRIZ G. & 57,6 & 73,3 & 77,4 & 98,1 & 11,4 & 17,5 & 26,8 & 48,8 \\
\hline BRUNA S. & 79,8 & 85,8 & 85 & 108 & 14 & 23 & 31,1 & 53,2 \\
\hline CAMILA S. & 65,8 & 81,4 & 86,6 & 105,4 & 12,6 & 21,9 & 28,9 & 54,5 \\
\hline DAVI M. & 60 & 75,8 & 83,8 & 109,2 & 17,1 & 28,4 & 36,6 & 64,7 \\
\hline ERICK B. & 81,3 & 89,8 & 88,4 & 109,8 & 15,8 & 26,5 & 34,6 & 57,9 \\
\hline ERIC R. & 61,6 & 86 & 91 & 118,5 & 15,5 & 25,3 & 27 & 51,7 \\
\hline FERNANDO O. & 64,6 & 69,6 & 72,4 & 99,2 & 12,6 & 22 & 29,8 & 54 \\
\hline FLÁVIA R. & 57,8 & 72,2 & 83 & 109,8 & 11,6 & 20,4 & 29,2 & 53,8 \\
\hline GABRIEL P. & 68,7 & 76,4 & 81 & 102 & 12 & 21,1 & 29,5 & 54,3 \\
\hline GUILHERME F. & 73,4 & 93,1 & 89,5 & 108,4 & 18,4 & 28,2 & 37,1 & 63,9 \\
\hline GUILHERME T. & 67,7 & 77,5 & 79,9 & 104,4 & 9,9 & 22,6 & 28 & 53,6 \\
\hline HENRIQUE G. & 67,5 & 79,3 & 84,2 & 107,1 & 9,6 & 18,1 & 26,7 & 50 \\
\hline IRIS M. & 55,9 & 71,4 & 74,4 & 93,3 & 13 & 23,2 & 31,6 & 50,7 \\
\hline ISABELLE O. & 59,5 & 75,5 & 79,1 & 106,5 & 11,5 & 21,8 & 30,7 & 52,5 \\
\hline JÉSSICA G. & 65,7 & 75,8 & 87,9 & 106 & 15,6 & 25,2 & 34,3 & 59,7 \\
\hline JONATHAN H. & 69,5 & 76,9 & 83,8 & 110,3 & 10,8 & 21,3 & 29,1 & 53,1 \\
\hline JOSÉ ORLANDO R. & 73,7 & 82 & 78 & 117,5 & 9,8 & 17,9 & 26,1 & 56,6 \\
\hline KAROLYNE S. & 69,5 & 77,2 & 81,2 & 102,6 & 13,9 & 23,3 & 31,6 & 56,6 \\
\hline LIVIA S. & 65,6 & 83,2 & 88,6 & 113,6 & 14,1 & 22,9 & 31,8 & 58,1 \\
\hline LUCAS A. & 64,5 & 81,6 & 85,8 & 112,1 & 11,3 & 21,4 & 29,4 & 54,1 \\
\hline LUIZ HENRIQUE T. & 65,2 & 77,5 & 76,2 & 106,5 & 12,7 & 23,1 & 31,5 & 58,2 \\
\hline MICHELE F. & 50,6 & 66,2 & 71,7 & 106,6 & 10,5 & 18,5 & 26,4 & 53,6 \\
\hline PAULO RICARDO R. & 66,7 & 79,1 & 82,4 & 103,5 & 14,9 & 24,6 & 33,8 & 59,7 \\
\hline PRISCILA R. & 72,2 & 77,5 & 83 & 116,8 & 15,2 & 22,8 & 30,6 & 57,4 \\
\hline RAFAEL V. & 65,2 & 74,8 & 79 & 98,5 & 12,7 & 21,8 & 29,8 & 52 \\
\hline TAMARA S. & 71,4 & 75,3 & 78,1 & 112 & 11,7 & 20,5 & 29,1 & 55 \\
\hline VALESKA B. & 63 & 71,6 & 75,5 & 102 & 11,4 & 21,3 & 29,6 & 51 \\
\hline
\end{tabular}


Apêndice 3 - Dados referentes à avaliação das telerradiografias em norma lateral da fase inicial.

\begin{tabular}{|c|c|c|c|c|c|c|}
\hline PACIENTES & PP-7 & PP-6 & PP-5 & PP-1 & OVERJET & OVERBITE \\
\hline ALINE C. & 9,3 & 15,8 & 17,7 & 25,6 & 7 & 5 \\
\hline ANDRÉ R. & 11 & 14,6 & 16,9 & 25,9 & 7,5 & 6,6 \\
\hline ARIENE S. & 17,2 & 19,5 & 21,8 & 27,6 & 4,2 & 3,6 \\
\hline BEATRIZ G. & 4,3 & 14 & 16,5 & 26,2 & 4,2 & 5,8 \\
\hline BRUNA S. & 12,5 & 15,4 & 16,6 & 24,7 & 6 & 4,9 \\
\hline CAMILA S. & 13 & 16,3 & 17,3 & 23,5 & 4,3 & 3,6 \\
\hline DAVI M. & 16,1 & 20,1 & 21,5 & 29,1 & 4 & 2,8 \\
\hline ERICK B. & 15 & 17,7 & 19 & 25,1 & 4,8 & 3,7 \\
\hline ERIC R. & 10,7 & 17 & 17,6 & 22,9 & 4,8 & 2 \\
\hline FERNANDO O. & 13,6 & 16,7 & 18,8 & 27,4 & 5,8 & 6,2 \\
\hline FLÁVIA R. & 12,8 & 16,8 & 19,8 & 25,7 & 3 & 2,5 \\
\hline GABRIEL P. & 15,5 & 18,9 & 20,4 & 26,6 & 3,6 & 2,1 \\
\hline GUILHERME F. & 14,1 & 15,4 & 15,3 & 22,9 & 4,9 & 4,5 \\
\hline GUILHERME T. & 13,4 & 16,6 & 18,7 & 26,7 & 4,1 & 4,3 \\
\hline HENRIQUE G. & 8,9 & 18,9 & 21,9 & 29,2 & 4,6 & 2,7 \\
\hline IRIS M. & 16,5 & 19,9 & 21,4 & 27,6 & 2,7 & 3,9 \\
\hline ISABELLE O. & 11,7 & 18,1 & 20,9 & 29,3 & 3 & 1,7 \\
\hline JÉSSICA G. & 13,1 & 15,7 & 16,9 & 20,5 & 6,3 & 5,6 \\
\hline JONATHAN H. & 8,3 & 13,7 & 16 & 25,7 & 5,4 & 4,7 \\
\hline JOSÉ ORLANDO R. & 3,8 & 15 & 17,2 & 23,4 & 7,1 & 4,2 \\
\hline KAROLYNE S. & 17,3 & 20,6 & 22,3 & 29,4 & 5,4 & 4,1 \\
\hline LIVIA S. & 13,4 & 16,8 & 17,9 & 22,7 & 4,6 & 3,3 \\
\hline LUCAS A. & 12,6 & 17,8 & 19,8 & 27,1 & 4,3 & 4,3 \\
\hline LUIZ HENRIQUE T. & 15,2 & 18,7 & 22,2 & 30,2 & 3,7 & 2,9 \\
\hline MICHELE F. & 5 & 14,9 & 18 & 29,3 & 7,4 & 5,2 \\
\hline PAULO RICARDO R. & 17,6 & 21,9 & 23,3 & 32,5 & 2 & 3,1 \\
\hline PRISCILA R. & 5,6 & 13,9 & 15,2 & 19,5 & 4,9 & 3,5 \\
\hline RAFAEL V. & 12 & 15,3 & 17,9 & 27,8 & 2,5 & 4,6 \\
\hline TAMARA S. & 14,3 & 17 & 19,5 & 26,9 & 9,4 & 7,2 \\
\hline VALESKA B. & 11,8 & 15,8 & 18,4 & 25,3 & 5,4 & 5,3 \\
\hline
\end{tabular}


Apêndice 4 - Dados referentes à avaliação das telerradiografias em norma lateral da fase inicial.

\begin{tabular}{|c|c|c|c|c|c|c|c|}
\hline PACIENTES & ANL & E-LS & E-Li & FMA & SN.GoGn & NS.Gn & AFAI \\
\hline ALINE C. & 86,7 & 3,7 & 0,6 & 26,1 & 34,3 & 57,6 & 59,9 \\
\hline ANDRÉ R. & 116,1 & 3,6 & 0,7 & 27 & 33,4 & 57,1 & 62 \\
\hline ARIENE S. & 94,9 & 1,8 & $-0,6$ & 15,4 & 26,7 & 58 & 60,8 \\
\hline BEATRIZ G. & 159,4 & 2,6 & 0,2 & 31 & 35,6 & 52,7 & 55,3 \\
\hline BRUNA S. & 120,4 & 1,3 & 0,4 & 23,1 & 29,6 & 54,8 & 56,5 \\
\hline CAMILA S. & 115,4 & 4,3 & 1,5 & 20,2 & 29,7 & 51,7 & 53,5 \\
\hline DAVI M. & 114,7 & $-1,2$ & $-2,4$ & 30,8 & 35,9 & 63,1 & 66,7 \\
\hline ERICK B. & 84,8 & 5,4 & 3,3 & 20,1 & 27,9 & 58,1 & 59,7 \\
\hline ERIC R. & 105,5 & 4,8 & 6 & 22,5 & 19,2 & 51,8 & 55,9 \\
\hline FERNANDO O. & 122,5 & 1,2 & 0,8 & 30,5 & 37 & 59,6 & 63 \\
\hline FLÁVIA R. & 95,8 & 4,3 & $-0,1$ & 29,3 & 36,9 & 57,2 & 59,5 \\
\hline GABRIEL P. & 114,4 & 1,7 & $-0,5$ & 27,7 & 36,6 & 66,6 & 69,6 \\
\hline GUILHERME F. & 104,2 & 3 & 1,6 & 24,1 & 32,8 & 55 & 56,3 \\
\hline GUILHERME T. & 96,9 & $-0,8$ & -3 & 24,7 & 33,2 & 56,9 & 60,7 \\
\hline HENRIQUE G. & 105,6 & 0,3 & -1 & 33,3 & 35,3 & 62,3 & 65,1 \\
\hline IRIS M. & 103,8 & 2,6 & $-0,2$ & 27,1 & 37 & 61,3 & 64,8 \\
\hline ISABELLE O. & 105,1 & 4,8 & 0,5 & 29,3 & 35,5 & 61,8 & 63,9 \\
\hline JÉSSICA G. & 119,9 & $-0,4$ & 1,2 & 19,8 & 28,4 & 49,3 & 52,3 \\
\hline JONATHAN H. & 82,6 & 2,8 & 2,6 & 28,2 & 30,1 & 57,4 & 59,9 \\
\hline JOSÉ ORLANDO R. & 89,4 & $-1,1$ & $-0,6$ & 22,4 & 27,7 & 54,9 & 58,1 \\
\hline KAROLYNE S. & 101 & 2,6 & 0,6 & 32,8 & 34,5 & 64,5 & 68,7 \\
\hline LIVIA S. & 103,4 & 3,4 & $-0,1$ & 28 & 26 & 52,6 & 55,6 \\
\hline LUCAS A. & 115,1 & 0,7 & 0,6 & 31,3 & 31,6 & 60 & 62,7 \\
\hline LUIZ HENRIQUE T. & 107,8 & -4 & -5 & 32,3 & 36 & 62,6 & 66,5 \\
\hline MICHELE F. & 99,1 & $-0,5$ & -1 & 25,4 & 37,1 & 60,3 & 61,6 \\
\hline PAULO RICARDO R. & 113,9 & $-1,2$ & -5 & 28,3 & 32,7 & 68,7 & 71,6 \\
\hline PRISCILA R. & 103,9 & 1,8 & $-1,3$ & 21,4 & 25,1 & 47,8 & 51 \\
\hline RAFAEL V. & 101,6 & $-2,1$ & 0,3 & 33,4 & 37,4 & 62,2 & 65,5 \\
\hline TAMARA S. & 121,3 & 2,7 & 3,4 & 21 & 26,6 & 61,1 & 64,2 \\
\hline VALESKA B. & 105 & 2,6 & 2,4 & 24 & 31,3 & 53,6 & 55,4 \\
\hline
\end{tabular}


Apêndice 5 - Dados referentes à avaliação das telerradiografias em norma lateral da fase inicial.

\begin{tabular}{|c|c|c|c|c|c|}
\hline PACIENTES & SNA & SNB & ANB & PTV-A & PTV-B \\
\hline ALINE C. & 77,3 & 75,3 & 2 & 40,9 & 35,4 \\
\hline ANDRÉ R. & 76 & 73 & 3 & 52 & 50,7 \\
\hline ARIENE S. & 86,3 & 81,2 & 5,1 & 55,7 & 55,8 \\
\hline BEATRIZ G. & 78,6 & 75,6 & 2,9 & 44,1 & 43,7 \\
\hline BRUNA S. & 85,2 & 81,8 & 3,5 & 44,4 & 46,4 \\
\hline CAMILA S. & 83,8 & 80,3 & 3,5 & 49,2 & 49,7 \\
\hline DAVI M. & 88,1 & 80,6 & 7,5 & 55,8 & 53,8 \\
\hline ERICK B. & 83,3 & 83,7 & $-0,4$ & 50,3 & 54,7 \\
\hline ERIC R. & 85,3 & 85,2 & 0,1 & 44 & 43 \\
\hline FERNANDO O. & 82,5 & 75,5 & 7 & 49,7 & 44 \\
\hline FLÁVIA R. & 79 & 78 & 1 & 43,3 & 48 \\
\hline GABRIEL P. & 83,7 & 77,5 & 6,2 & 50,3 & 42,1 \\
\hline GUILHERME F. & 91,3 & 85,7 & 5,6 & 57,4 & 58,3 \\
\hline GUILHERME T. & 74,2 & 72 & 2,2 & 44,4 & 43,8 \\
\hline HENRIQUE G. & 83,7 & 80 & 3,8 & 45,4 & 41,7 \\
\hline IRIS M. & 76,5 & 72,3 & 4,2 & 45,6 & 45 \\
\hline ISABELLE O. & 80 & 78,1 & 1,9 & 44,6 & 47,8 \\
\hline JÉSSICA G. & 90 & 80,5 & 9,5 & 53,6 & 49,9 \\
\hline JONATHAN H. & 84,3 & 81,3 & 3 & 45,6 & 45,6 \\
\hline JOSÉ ORLANDO R. & 85,9 & 81,1 & 4,8 & 47,2 & 45,4 \\
\hline KAROLYNE S. & 86,4 & 80,5 & 5,9 & 52,1 & 46,7 \\
\hline LIVIA S. & 89,6 & 85,6 & 4 & 48 & 51,2 \\
\hline LUCAS A. & 85,8 & 82,4 & 3,4 & 46,4 & 43,1 \\
\hline LUIZ HENRIQUE T. & 79,5 & 76,2 & 3,3 & 48,4 & 46,4 \\
\hline MICHELE F. & 80,8 & 75,4 & 5,4 & 45,3 & 40,7 \\
\hline PAULO RICARDO R. & 84,6 & 81,7 & 2,9 & 50 & 52,8 \\
\hline PRISCILA R. & 87,1 & 82,8 & 4,3 & 50,9 & 47,9 \\
\hline RAFAEL V. & 79,1 & 76,1 & 3 & 46,5 & 45,7 \\
\hline TAMARA S. & 85,4 & 80 & 5,4 & 49,3 & 42,1 \\
\hline VALESKA B. & 79,8 & 77,8 & 2 & 44,7 & 45,4 \\
\hline
\end{tabular}


Apêndice 6 - Dados referentes à avaliação das telerradiografias em norma lateral da fase final.

\begin{tabular}{|c|c|c|c|c|c|c|c|c|}
\hline PACIENTES & SN.7 & SN.6 & SN.5 & SN.1 & PTV-7 & PTV-6 & PTV-5 & PTV-1 \\
\hline ALINE C. & 57,7 & 64,2 & 98 & 115,2 & 5 & 12,8 & 25,8 & 46,3 \\
\hline ANDRÉ R. & 57 & 66,8 & 88,8 & 110,7 & 12,5 & 21,2 & 36,2 & 62,8 \\
\hline ARIENE S. & 71,8 & 73,1 & 92,5 & 108,3 & 19,1 & 28,2 & 40,3 & 65,8 \\
\hline BEATRIZ G. & 49,2 & 59,6 & 85,1 & 94,1 & 7,6 & 15,3 & 29 & 47,7 \\
\hline BRUNA S. & 72,5 & 76,7 & 95,5 & 112,8 & 12,6 & 22 & 33,5 & 55 \\
\hline CAMILA S. & 60 & 73,3 & 92,3 & 108,3 & 10,9 & 20,6 & 34,3 & 58,4 \\
\hline DAVI M. & 60,9 & 70,7 & 88,4 & 110,1 & 17,8 & 27,4 & 41,3 & 68,2 \\
\hline ERICK B. & 66,2 & 83,4 & 97,1 & 118,2 & 8,6 & 18,6 & 31,3 & 54,6 \\
\hline ERIC R. & 70,1 & 76,8 & 97,7 & 113,5 & 8,8 & 18,5 & 37,2 & 60,1 \\
\hline FERNANDO O. & 58,4 & 66,1 & 87,7 & 104 & 12,1 & 21,4 & 33,8 & 55,7 \\
\hline FLÁVIA R. & 56,1 & 64,3 & 93 & 115,1 & 12,2 & 20,5 & 34,2 & 56,3 \\
\hline GABRIEL P. & 61,7 & 70,2 & 90,6 & 101,6 & 9 & 18,1 & 31 & 52,7 \\
\hline GUILHERME F. & 68,7 & 77,5 & 98,7 & 110,5 & 14,6 & 25,7 & 40,9 & 64,3 \\
\hline GUILHERME T. & 69,3 & 75 & 87,6 & 108,1 & 12,4 & 19,3 & 32,8 & 57,5 \\
\hline HENRIQUE G. & 49,4 & 65 & 92,9 & 108,7 & 7,4 & 16,2 & 29,8 & 53,1 \\
\hline IRIS M. & 51,9 & 63,9 & 88 & 96,3 & 9,4 & 19,2 & 34,1 & 50,1 \\
\hline ISABELLE O. & 65,8 & 72,4 & 87,8 & 111,4 & 12,3 & 21,3 & 34,8 & 55,8 \\
\hline JÉSSICA G. & 60,2 & 74,3 & 100,2 & 108,6 & 15,1 & 24,4 & 39,5 & 61,7 \\
\hline JONATHAN H. & 62,7 & 66 & 101 & 121,3 & 7,9 & 18,1 & 32,4 & 56,5 \\
\hline JOSÉ ORLANDO R. & 63,8 & 65,9 & 92,8 & 117,8 & 9 & 17,2 & 30,2 & 57,5 \\
\hline KAROLYNE S. & 57,7 & 57,3 & 106,2 & 121,6 & 11,8 & 20,3 & 35,7 & 62 \\
\hline LIVIA S. & 58,6 & 81,7 & 92,1 & 113,1 & 12,8 & 22,8 & 36 & 59,8 \\
\hline LUCAS A. & 62,6 & 67 & 84,8 & 111,8 & 10 & 18,7 & 32,1 & 56 \\
\hline LUIZ HENRIQUE T. & 59 & 64,8 & 81,7 & 106,3 & 9,5 & 18,7 & 32,5 & 58 \\
\hline MICHELE F. & 48,9 & 56,3 & 83,7 & 110,7 & 7,9 & 16,2 & 29,2 & 53,6 \\
\hline PAULO RICARDO R. & 59,5 & 69,2 & 89 & 109 & 12,2 & 22 & 34,3 & 61,1 \\
\hline PRISCILA R. & 58 & 69,9 & 89,7 & 113,3 & 13 & 20,1 & 32 & 56,2 \\
\hline RAFAEL V. & 58,8 & 62,7 & 88,7 & 106,9 & 11,4 & 20,2 & 34 & 54,7 \\
\hline TAMARA S. & 60,4 & 66,4 & 90,9 & 118,7 & 10,3 & 18,5 & 33,3 & 58 \\
\hline VALESKA B. & 61,3 & 70,5 & 81,6 & 97,6 & 11,7 & 20,2 & 30,7 & 52,5 \\
\hline
\end{tabular}


Apêndice 7 - Dados referentes à avaliação das telerradiografias em norma lateral da fase final.

\begin{tabular}{|c|c|c|c|c|c|c|}
\hline PACIENTES & PP-7 & PP-6 & PP-5 & PP-1 & OVERJET & OVERBITE \\
\hline ALINE C. & 11,8 & 15,8 & 21,3 & 26,9 & 8 & 5,4 \\
\hline ANDRÉ R. & 12 & 15,6 & 19,2 & 27,1 & 8,4 & 5,8 \\
\hline ARIENE S. & 15,9 & 19,1 & 22,3 & 27,5 & 3,7 & 3,6 \\
\hline BEATRIZ G. & 4,8 & 12,3 & 18,8 & 26,7 & 3,7 & 5,2 \\
\hline BRUNA S. & 12,1 & 15,6 & 17,8 & 24,5 & 5,2 & 4,3 \\
\hline CAMILA S. & 11,1 & 14,9 & 18,8 & 24,6 & 5,5 & 3,9 \\
\hline DAVI M. & 15,5 & 19,5 & 24,4 & 29,3 & 5,4 & 0,7 \\
\hline ERICK B. & 12,2 & 15,9 & 18,6 & 23 & 6 & 1,4 \\
\hline ERIC R. & 15,2 & 18 & 20,7 & 26,4 & 4,5 & 3,5 \\
\hline FERNANDO O. & 11 & 16,2 & 20 & 27,7 & 6,2 & 6,1 \\
\hline FLÁVIA R. & 11,9 & 16,6 & 19,7 & 26,4 & 3,3 & 0,7 \\
\hline GABRIEL P. & 15,3 & 18,5 & 21,1 & 27,4 & 3,6 & 1,4 \\
\hline GUILHERME F. & 14 & 16,5 & 18,8 & 23,7 & 5,9 & 1,9 \\
\hline GUILHERME T. & 16,3 & 18,2 & 19,9 & 25,8 & 4,7 & 4,4 \\
\hline HENRIQUE G. & 11,1 & 18 & 22,7 & 28,8 & 6,9 & 1,9 \\
\hline IRIS M. & 15,6 & 19,7 & 21,8 & 27,7 & 3,9 & 2,9 \\
\hline ISABELLE O. & 13,1 & 17,7 & 22,6 & 30,1 & 3,3 & 0,3 \\
\hline JÉSSICA G. & 13 & 15,9 & 17,4 & 20,3 & 8,3 & 5 \\
\hline JONATHAN H. & 8,3 & 13,5 & 17,2 & 25,9 & 9,1 & 3,2 \\
\hline JOSÉ ORLANDO R. & 4,7 & 15,3 & 19,3 & 24,7 & 8,1 & 4,5 \\
\hline KAROLYNE S. & 17,2 & 20,9 & 25,1 & 27,3 & 12,3 & 0,3 \\
\hline LIVIA S. & 15,9 & 18,4 & 20,3 & 24,5 & 4,5 & 4,3 \\
\hline LUCAS A. & 12,6 & 17,5 & 22,3 & 27 & 6,4 & 2,4 \\
\hline LUIZ HENRIQUE T. & 14,2 & 18,1 & 23,6 & 31,4 & 3,6 & 3,9 \\
\hline MICHELE F. & 6 & 13,5 & 20,8 & 28,5 & 9,1 & 4,2 \\
\hline PAULO RICARDO R. & 16,9 & 21,3 & 24,6 & 30,9 & 3,8 & 2,3 \\
\hline PRISCILA R. & 9,7 & 14,6 & 17,2 & 22 & 3,6 & 2,8 \\
\hline RAFAEL V. & 11,2 & 15,5 & 21,3 & 28,2 & 5,1 & 3,8 \\
\hline TAMARA S. & 10,9 & 15 & 20 & 26,5 & 10,2 & 5,6 \\
\hline VALESKA B. & 11,6 & 16,3 & 19,6 & 27,8 & 4,7 & 6,3 \\
\hline
\end{tabular}


Apêndice 8 - Dados referentes à avaliação das telerradiografias em norma lateral da fase final.

\begin{tabular}{|c|c|c|c|c|c|c|c|}
\hline PACIENTES & ANL & E-LS & E-Li & FMA & SN.GoGn & NS.Gn & AFAI \\
\hline ALINE C. & 91,5 & 1,8 & 1,4 & 27,7 & 33,2 & 59,8 & 61,8 \\
\hline ANDRÉ R. & 113,7 & 3,4 & 0,5 & 21,6 & 32,6 & 61,3 & 64,4 \\
\hline ARIENE S. & 103,7 & 1,4 & $-1,9$ & 14,6 & 24,7 & 58,9 & 60,8 \\
\hline BEATRIZ G. & 125,8 & 3,5 & 1,2 & 33,9 & 38,5 & 54,2 & 57,1 \\
\hline BRUNA S. & 107,6 & 1 & 0,2 & 22,8 & 29,8 & 55,9 & 57,5 \\
\hline CAMILA S. & 110 & 3,8 & 0,3 & 21,8 & 31,9 & 52,7 & 54,4 \\
\hline DAVI M. & 106,2 & 0,5 & $-2,5$ & 35,6 & 38,9 & 66,8 & 71,4 \\
\hline ERICK B. & 98,4 & 3,1 & 0,8 & 22,5 & 23,4 & 56,6 & 58,4 \\
\hline ERIC R. & 89,4 & 6,5 & 4,9 & 21,2 & 28,8 & 60,4 & 62,1 \\
\hline FERNANDO O. & 112,6 & 1,1 & $-0,2$ & 30 & 36,4 & 61,4 & 64,2 \\
\hline FLÁVIA R. & 96,2 & 3,5 & -1 & 29,2 & 36,9 & 58,6 & 60,6 \\
\hline GABRIEL P. & 115,4 & 0,3 & $-1,7$ & 32,3 & 35,6 & 66,5 & 71,5 \\
\hline GUILHERME F. & 99 & 1,4 & $-0,5$ & 26,8 & 33,6 & 59,4 & 62,5 \\
\hline GUILHERME T. & 104,7 & $-1,6$ & $-1,5$ & 29,9 & 33,2 & 60,7 & 65,8 \\
\hline HENRIQUE G. & 112,1 & 1,6 & 1,3 & 31,8 & 35,6 & 63,1 & 65,8 \\
\hline IRIS M. & 109,2 & 2,8 & $-0,2$ & 30,3 & 37,6 & 62,4 & 66,7 \\
\hline ISABELLE O. & 112,4 & 5,8 & $-0,5$ & 30,2 & 31,8 & 64,5 & 66,7 \\
\hline JÉSSICA G. & 119,7 & $-1,2$ & 1,1 & 21,8 & 30,8 & 51,5 & 54 \\
\hline JONATHAN H. & 99,1 & 0,6 & 1 & 29,4 & 31,1 & 59 & 61,9 \\
\hline JOSÉ ORLANDO R. & 93,4 & $-1,6$ & $-1,1$ & 21,6 & 28,9 & 57,9 & 60,8 \\
\hline KAROLYNE S. & 94,8 & 3,1 & $-0,4$ & 32,4 & 34,7 & 67 & 71,2 \\
\hline LIVIA S. & 107,3 & 2,5 & $-0,8$ & 25,5 & 24,2 & 54,8 & 57,6 \\
\hline LUCAS A. & 109,6 & -1 & 0,1 & 33,1 & 36,1 & 62,1 & 65,3 \\
\hline LUIZ HENRIQUE T. & 104,9 & $-3,7$ & $-4,6$ & 33,3 & 36,5 & 63,9 & 68,1 \\
\hline MICHELE F. & 92,1 & $-1,6$ & $-2,9$ & 26,8 & 37,2 & 60,5 & 62,1 \\
\hline PAULO RICARDO R. & 109,4 & $-1,1$ & $-4,8$ & 28,4 & 34 & 69,2 & 72,6 \\
\hline PRISCILA R. & 92,8 & 1,6 & $-2,4$ & 21 & 26,8 & 51 & 53,5 \\
\hline RAFAEL V. & 99,4 & $-1,5$ & 0,1 & 33,4 & 39,2 & 65,5 & 68,6 \\
\hline TAMARA S. & 111,2 & 0,8 & 2,3 & 18,8 & 23,6 & 59,8 & 64 \\
\hline VALESKA B. & 100,3 & 2,2 & 0,3 & 24,3 & 31,7 & 56,9 & 58,5 \\
\hline
\end{tabular}


Apêndice 9 - Dados referentes à avaliação das telerradiografias em norma lateral da fase final.

\begin{tabular}{|c|c|c|c|c|c|}
\hline PACIENTES & SNA & SNB & ANB & PTV-A & PTV-B \\
\hline ALINE C. & 78,1 & 76,4 & 1,7 & 41,1 & 35,4 \\
\hline ANDRÉ R. & 77,4 & 73,8 & 3,7 & 53,4 & 51,4 \\
\hline ARIENE S. & 86,1 & 82,2 & 3,9 & 54,5 & 56,4 \\
\hline BEATRIZ G. & 78 & 74,9 & 3,2 & 43,7 & 42,1 \\
\hline BRUNA S. & 85 & 81,7 & 3,3 & 45,8 & 48,5 \\
\hline CAMILA S. & 84,2 & 79,6 & 4,6 & 50,6 & 51,9 \\
\hline DAVI M. & 89 & 80,5 & 8,6 & 58,4 & 56,4 \\
\hline ERICK B. & 85,7 & 85,5 & 0,2 & 46,1 & 46,9 \\
\hline ERIC R. & 83,3 & 83,6 & $-0,3$ & 51,9 & 56,7 \\
\hline FERNANDO O. & 81,3 & 75,1 & 6,2 & 50,2 & 44,2 \\
\hline FLÁVIA R. & 78,6 & 78 & 0,6 & 43,9 & 50,3 \\
\hline GABRIEL P. & 83,9 & 77,7 & 6,3 & 49,3 & 39,2 \\
\hline GUILHERME F. & 90,1 & 85 & 5,1 & 56,9 & 57,7 \\
\hline GUILHERME T. & 80,3 & 75,8 & 4,4 & 49,8 & 46,6 \\
\hline HENRIQUE G. & 84,6 & 79,7 & 5 & 46,1 & 42,1 \\
\hline IRIS M. & 77,7 & 72,8 & 4,9 & 45,2 & 43,4 \\
\hline ISABELLE O. & 82,2 & 81,4 & 0,8 & 45,7 & 51,4 \\
\hline JÉSSICA G. & 89,2 & 78,7 & 10,5 & 54 & 50 \\
\hline JONATHAN H. & 86,4 & 81,9 & 4,6 & 46,8 & 45,8 \\
\hline JOSÉ ORLANDO R. & 87,1 & 80,9 & 6,3 & 48,9 & 45 \\
\hline KAROLYNE S. & 86,2 & 79,8 & 6,4 & 52,3 & 46,6 \\
\hline LIVIA S. & 89,6 & 85,6 & 4 & 49 & 52,7 \\
\hline LUCAS A. & 84,2 & 79,5 & 4,7 & 46,7 & 42,4 \\
\hline LUIZ HENRIQUE T. & 80 & 76,4 & 3,6 & 48,3 & 44,8 \\
\hline MICHELE F. & 80,5 & 76,1 & 4,4 & 44 & 38,8 \\
\hline PAULO RICARDO R. & 85,4 & 80,9 & 4,5 & 51,4 & 51,2 \\
\hline PRISCILA R. & 86 & 81,6 & 4,3 & 50,2 & 46,4 \\
\hline RAFAEL V. & 78,3 & 75,1 & 3,1 & 47 & 44,9 \\
\hline TAMARA S. & 86,2 & 81,6 & 4,7 & 49,5 & 43,9 \\
\hline VALESKA B. & 79,1 & 77,7 & 1,4 & 45,4 & 47,4 \\
\hline
\end{tabular}


Apêndice 10 - Dados referentes à remedição das telerradiografias em norma lateral de 20 pacientes selecionados aleatoriamente.

\begin{tabular}{l|r|r|r|r|r|r|r|r}
\hline \hline \multicolumn{1}{c|}{ PACIENTES } & \multicolumn{1}{c|}{ SN.7 } & \multicolumn{1}{c|}{ SN.6 } & \multicolumn{1}{c|}{ SN.5 } & \multicolumn{1}{c|}{ SN.1 } & PTV-7 & PTV-6 & PTV-5 & PTV-1 \\
\hline ANDRÉ R. & 59,9 & 70,2 & 88,9 & 109,5 & 11,8 & 21,6 & 36,6 & 63,2 \\
\hline ARIENE S. & 68,5 & 77,2 & 93,9 & 109,9 & 16,1 & 26,5 & 41 & 64,5 \\
\hline BEATRIZ G. & 56 & 64,2 & 85,8 & 97,5 & 8,7 & 16,6 & 30 & 49,4 \\
\hline CAMILA S. & 68,5 & 84,2 & 87,3 & 106,2 & 10,9 & 20,5 & 28,1 & 54 \\
\hline DAVI M. & 61,3 & 70,5 & 94 & 113,6 & 15,9 & 25,9 & 40,7 & 68,6 \\
\hline ERIC R. & 68 & 89,7 & 93,9 & 118,5 & 8 & 17,9 & 26,8 & 51,8 \\
\hline GABRIEL P. & 63,2 & 69,3 & 88,8 & 104,5 & 9,7 & 19,2 & 32,8 & 55,2 \\
\hline GUILHERME T. & 71,2 & 76,5 & 83,4 & 108,4 & 12,4 & 22,1 & 34,1 & 58,2 \\
\hline HENRIQUE G. & 67,1 & 83,4 & 85,8 & 104,1 & 9,2 & 18,4 & 26,6 & 50,9 \\
\hline IRIS M. & 58,8 & 78,5 & 77,7 & 95,1 & 11,4 & 21,3 & 29,8 & 51,2 \\
\hline ISABELLE O. & 66,5 & 85,6 & 84,9 & 105,6 & 11,2 & 20,2 & 29,6 & 51,4 \\
\hline JOSÉ ORLANDO R. & 64,5 & 65,4 & 93,3 & 115,9 & 9,3 & 15,8 & 28,6 & 56,3 \\
\hline LIVIA S. & 64,2 & 82,2 & 88,5 & 108,7 & 15,1 & 24 & 32,6 & 59,5 \\
\hline LUIZ HENRIQUE T. & 65,9 & 75,3 & 75,9 & 106 & 12,5 & 22,2 & 31,4 & 58,2 \\
\hline MICHELE F. & 55,8 & 70,8 & 76,7 & 105,7 & 10,6 & 18,2 & 27,2 & 53,3 \\
\hline PAULO RICARDO R. & 62,3 & 70,2 & 89,7 & 110,6 & 15,1 & 25,4 & 38 & 65,1 \\
\hline PRISCILA R. & 56,8 & 69 & 94,9 & 114,4 & 13,5 & 20,3 & 32,6 & 58,5 \\
\hline RAFAEL V. & 66,5 & 81 & 78,6 & 95,6 & 10,9 & 21,2 & 29 & 50,7 \\
\hline TAMARA S. & 71 & 77,4 & 82,6 & 114,8 & 12,3 & 21,1 & 30,6 & 56,5 \\
\hline VALESKA B. & 68,9 & 88,3 & 100,1 & 13,9 & 21,5 & 32,3 & 54,5 \\
\hline \hline
\end{tabular}


Apêndice 11 - Dados referentes à remedição das telerradiografias em norma lateral de 20 pacientes selecionados aleatoriamente.

\begin{tabular}{|c|c|c|c|c|c|c|}
\hline PACIENTES & PP-7 & PP-6 & PP-5 & PP-1 & OVERJET & OVERBITE \\
\hline ANDRÉ R. & 12,3 & 16,5 & 19,2 & 26,5 & 7,9 & 5,3 \\
\hline ARIENE S. & 15,7 & 19,2 & 21,9 & 28 & 4,4 & 3,6 \\
\hline BEATRIZ G. & 4,9 & 13,5 & 18,9 & 26,9 & 3,6 & 5,8 \\
\hline CAMILA S. & 12,9 & 16,3 & 17,2 & 25,2 & 4,5 & 4,1 \\
\hline DAVI M. & 14,7 & 19,3 & 23,5 & 30,9 & 5,2 & 1,3 \\
\hline ERIC R. & 11,1 & 16,6 & 17,6 & 23,5 & 3,9 & 2,4 \\
\hline GABRIEL P. & 15,4 & 18,9 & 21,6 & 26,9 & 2,7 & 0,7 \\
\hline GUILHERME T. & 17,6 & 19,7 & 20,2 & 26,3 & 4,5 & 4,3 \\
\hline HENRIQUE G. & 9,8 & 19,8 & 20,9 & 30,6 & 3,8 & 3 \\
\hline IRIS M. & 14,1 & 19,4 & 20,2 & 29,1 & 3,3 & 5,1 \\
\hline ISABELLE O. & 14 & 18,7 & 20,6 & 29,2 & 2,8 & 1,5 \\
\hline JOSÉ ORLANDO R. & 4,9 & 14,8 & 18,5 & 25,6 & 7,4 & 4,7 \\
\hline LIVIA S. & 13,5 & 16,8 & 18,2 & 24,2 & 4,6 & 5 \\
\hline LUIZ HENRIQUE T. & 15,4 & 19,6 & 22,2 & 31,8 & 3,6 & 4,2 \\
\hline MICHELE F. & 6,1 & 15 & 18,1 & 29,7 & 7,5 & 5,9 \\
\hline PAULO RICARDO R. & 17,2 & 21,7 & 25,3 & 31,3 & 4 & 2,4 \\
\hline PRISCILA R. & 8,3 & 14,7 & 16,5 & 22,8 & 4,9 & 3,6 \\
\hline RAFAEL V. & 13 & 16,9 & 18,4 & 27,8 & 3,4 & 4,6 \\
\hline TAMARA S. & 12,2 & 15,5 & 17,4 & 26,7 & 9,2 & 7,1 \\
\hline VALESKA B. & 13,3 & 16,8 & 19,5 & 27,4 & 6 & 5,4 \\
\hline
\end{tabular}


Apêndice 12 - Dados referentes à remedição das telerradiografias em norma lateral de 20 pacientes selecionados aleatoriamente.

\begin{tabular}{l|r|r|r|r|r|r|r}
\hline \multicolumn{1}{c|}{ PACIENTES } & \multicolumn{1}{c|}{ ANL } & \multicolumn{1}{c|}{ E-LS } & \multicolumn{1}{c|}{ E-Li } & \multicolumn{1}{c|}{ FMA } & SN.GoGn & \multicolumn{1}{c|}{ NS.Gn } & \multicolumn{1}{c}{ AFAI } \\
\hline ANDRÉ R. & 115,9 & 3,6 & $-0,7$ & 23,3 & 32,9 & 60,8 & 64,4 \\
\hline ARIENE S. & 96,4 & 0,9 & $-2,2$ & 16,2 & 25,3 & 58,9 & 61,4 \\
\hline BEATRIZ G. & 126,8 & 3,9 & 1,3 & 33,2 & 34,7 & 54,3 & 57,2 \\
\hline CAMILA S. & 115,3 & 4,8 & 0,7 & 22,7 & 29,5 & 52,4 & 54,6 \\
\hline DAVI M. & 101,9 & 0,4 & $-2,5$ & 33,8 & 33,9 & 66,6 & 72,6 \\
\hline ERIC R. & 100,5 & 4,2 & 2,8 & 23,3 & 20,6 & 53,3 & 56,5 \\
\hline GABRIEL P. & 107,7 & 1,8 & $-1,2$ & 32,9 & 35,4 & 65,8 & 71,1 \\
\hline GUILHERME T. & 93,9 & 1,3 & $-1,5$ & 27,7 & 30,9 & 59,8 & 64,8 \\
\hline HENRIQUE G. & 105,2 & 1,5 & $-0,8$ & 33 & 34,4 & 62,9 & 66 \\
\hline IRIS M. & 98,7 & 4 & 0,3 & 26,1 & 36,3 & 60,3 & 64,6 \\
\hline ISABELLE O. & 104,4 & 5,2 & 0,6 & 30 & 32,3 & 61,5 & 64,2 \\
\hline JOSÉ ORLANDO R. & 84,4 & $-1,4$ & $-0,4$ & 21,2 & 26,2 & 56,6 & 60,1 \\
\hline LIVIA S. & 100 & 3,2 & $-0,7$ & 26 & 24,7 & 52,6 & 56,3 \\
\hline LUIZ HENRIQUE T. & 101,6 & $-3,1$ & $-5,6$ & 32,4 & 35,3 & 63,3 & 67,6 \\
\hline MICHELE F. & 99,5 & $-0,5$ & $-1,6$ & 25,8 & 36 & 59,9 & 61,7 \\
\hline PAULO RICARDO R. & 100,1 & $-0,8$ & $-5,6$ & 28,7 & 33,9 & 69,7 & 73,1 \\
\hline PRISCILA R. & 85,7 & 2,7 & $-2,4$ & 22,8 & 25,9 & 50,5 & 53,8 \\
\hline RAFAEL V. & 92,1 & $-0,9$ & $-0,5$ & 33,2 & 38,4 & 62,3 & 65,4 \\
\hline TAMARA S. & 116,4 & 3,5 & 2,9 & 22,1 & 24 & 58,7 & 63,8 \\
\hline VALESKA B. & 2,9 & 0 & 23,3 & 30,2 & 56,4 & 58,2 \\
\hline \hline
\end{tabular}


Apêndice 13 - Dados referentes à remedição das telerradiografias em norma lateral de 20 pacientes selecionados aleatoriamente.

\begin{tabular}{|c|c|c|c|c|c|}
\hline PACIENTES & SNA & SNB & ANB & PTV-A & PTV-B \\
\hline ANDRÉ R. & 78,4 & 74,5 & 3,9 & 54,2 & 52,5 \\
\hline ARIENE S. & 87 & 83 & 4 & 53,5 & 55 \\
\hline BEATRIZ G. & 80,9 & 78,1 & 2,9 & 44,1 & 44,2 \\
\hline CAMILA S. & 84,1 & 80,7 & 3,4 & 47,9 & 48,6 \\
\hline DAVI M. & 91 & 82,7 & 8,4 & 58,6 & 56,8 \\
\hline ERIC R. & 86,1 & 85,6 & 0,6 & 44,7 & 43,3 \\
\hline GABRIEL P. & 82,9 & 78,6 & 4,3 & 48,8 & 40,5 \\
\hline GUILHERME T. & 79,6 & 75,8 & 3,8 & 50,1 & 48 \\
\hline HENRIQUE G. & 84,6 & 80,9 & 3,7 & 45,5 & 43,2 \\
\hline IRIS M. & 79,2 & 74,9 & 4,3 & 46,1 & 46,3 \\
\hline ISABELLE O. & 82,8 & 80,8 & 2,1 & 43,7 & 46,9 \\
\hline JOSÉ ORLANDO R. & 87,4 & 81,6 & 5,8 & 48,3 & 44,5 \\
\hline LIVIA S. & 88,2 & 84,8 & 3,5 & 48,5 & 52,2 \\
\hline LUIZ HENRIQUE T. & 79,6 & 76,4 & 3,2 & 47,9 & 46,5 \\
\hline MICHELE F. & 81,2 & 76,4 & 4,9 & 45 & 40,5 \\
\hline PAULO RICARDO R. & 83,6 & 80,1 & 3,5 & 52,9 & 52,2 \\
\hline PRISCILA R. & 86 & 82,2 & 3,9 & 50,8 & 47,1 \\
\hline RAFAEL V. & 78,6 & 75,4 & 3,2 & 46,3 & 43,8 \\
\hline TAMARA S. & 86,7 & 81 & 5,7 & 50,1 & 43,5 \\
\hline VALESKA B. & 81 & 78,9 & 2,2 & 47,1 & 47,2 \\
\hline
\end{tabular}


Apêndice 14 - Relação dos pacientes quanto à severidade da má oclusão de Classe II e a presença dos segundos molares superiores.

\begin{tabular}{|c|c|c|}
\hline PACIENTES & $\begin{array}{l}\text { SEVERIDADE DA } \\
\text { CLASSE II }\end{array}$ & $\begin{array}{c}\text { PRESENÇA DOS } \\
\text { SEGUNDOS MOLARES } \\
\text { SUPERIORES }\end{array}$ \\
\hline ALINE C. & $1 / 4$ & Sim \\
\hline ANDRÉ R. & $3 / 4$ & Sim \\
\hline ARIENE S. & $1 / 4$ & Sim \\
\hline BEATRIZ G. & $1 / 2$ & Não \\
\hline BRUNA S. & $1 / 2$ & Sim \\
\hline CAMILA S. & $1 / 4$ & Sim \\
\hline DAVI M. & $1 / 4$ & Sim \\
\hline ERICK B. & $1 / 4$ & Não \\
\hline ERIC R. & $1 / 2$ & Sim \\
\hline FERNANDO O. & $1 / 2$ & Sim \\
\hline FLÁVIA R. & $1 / 4$ & Sim \\
\hline GABRIEL P. & $1 / 2$ & Sim \\
\hline GUILHERME F. & $3 / 4$ & Sim \\
\hline GUILHERME T. & $1 / 4$ & Sim \\
\hline HENRIQUE G. & $1 / 2$ & Não \\
\hline IRIS M. & Completa & Sim \\
\hline ISABELLE O. & $1 / 2$ & Sim \\
\hline JÉSSICA G. & Completa & Sim \\
\hline JONATHAN H. & Completa & Não \\
\hline JOSÉ ORLANDO R. & $1 / 2$ & Não \\
\hline KAROLYNE S. & $3 / 4$ & Sim \\
\hline LIVIA S. & $1 / 2$ & Sim \\
\hline LUCAS A. & $1 / 2$ & Sim \\
\hline LUIZ HENRIQUE T. & $1 / 2$ & Sim \\
\hline MICHELE F. & $1 / 2$ & Não \\
\hline PAULO RICARDO R. & $1 / 4$ & Sim \\
\hline PRISCILA R. & $1 / 4$ & Não \\
\hline RAFAEL V. & $3 / 4$ & Sim \\
\hline TAMARA S. & Completa & Sim \\
\hline VALESKA B. & $3 / 4$ & Sim \\
\hline
\end{tabular}


Apêndice 15 - Valores relacionadas à obtenção da taxa de distalização mensal.

\begin{tabular}{|c|c|c|c|}
\hline PACIENTES & PTV-6 (final - inicial) & TEMPO & 0,086 x DIF./TEMPO \\
\hline ALINE C. & 1,5 & 0,79 & 0,157 \\
\hline ANDRÉ R. & 2,6 & 0,75 & 0,287 \\
\hline ARIENE S. & 1,9 & 1,43 & 0,111 \\
\hline BEATRIZ G. & 2,2 & 1,11 & 0,165 \\
\hline BRUNA S. & 1 & 0,86 & 0,096 \\
\hline CAMILA S. & 1,3 & 0,97 & 0,112 \\
\hline DAVI M. & 1 & 0,83 & 0,100 \\
\hline ERICK B. & 7,9 & 0,91 & 0,720 \\
\hline ERIC R. & 6,8 & 0,41 & 1,373 \\
\hline FERNANDO O. & 0,6 & 0,41 & 0,122 \\
\hline FLÁVIA R. & 0,1 & 1,02 & 0,008 \\
\hline GABRIEL P. & 3 & 0,62 & 0,400 \\
\hline GUILHERME F. & 2,5 & 0,81 & 0,258 \\
\hline GUILHERME T. & 3,3 & 1,95 & 0,140 \\
\hline HENRIQUE G. & 1,9 & 0,82 & 0,193 \\
\hline IRIS M. & 4 & 0,97 & 0,342 \\
\hline ISABELLE O. & 0,5 & 0,82 & 0,051 \\
\hline JÉSSICA G. & 0,8 & 0,98 & 0,068 \\
\hline JONATHAN H. & 3,2 & 0,50 & 0,534 \\
\hline JOSÉ ORLANDO R. & 0,7 & 0,58 & 0,100 \\
\hline KAROLYNE S. & 3 & 0,81 & 0,307 \\
\hline LIVIA S. & 0,1 & 0,94 & 0,009 \\
\hline LUCAS A. & 2,7 & 0,45 & 0,498 \\
\hline LUIZ HENRIQUE T. & 4,4 & 0,81 & 0,450 \\
\hline MICHELE F. & 2,3 & 0,89 & 0,214 \\
\hline PAULO RICARDO R. & 2,6 & 0,91 & 0,236 \\
\hline PRISCILA R. & 2,7 & 0,74 & 0,302 \\
\hline RAFAEL V. & 1,6 & 0,98 & 0,135 \\
\hline TAMARA S. & 2 & 1,18 & 0,141 \\
\hline VALESKA B. & 1,1 & 0,54 & 0,169 \\
\hline MÉDIA & 2,31 & 0,86 & 0,26 \\
\hline
\end{tabular}



